\title{
Secondo convegno
} dei geologi marini italiani

La geologia marina in Italia 23-24 febbraio 2017 - Aula Polifunzionale e Digital Gallery - CNR - P.le A. Moro, 7 - Roma 


\section{COORDINAMENTO:}

Francesco L. Chiocci (Università La Sapienza, CNR-IGAG),

Francesca Budillon (CNR-IAMC),

Silvia Ceramicola (OGS),

Fabiano Gamberi (CNR-ISMAR),

Maria Rosaria Senatore (Università del Sannio),

Attilio Sulli (Università di Palermo).

\section{SEGRETERIA TECNICA:}

Ionela Pintilie, pintilie.1719238@studenti.uniroma1.it

Maddalena Falco, maddalenafalco@outlook.com

Agostino Meo, agomeo@unisannio.it

Francesca Argiolas, francesca.argiolas@igag.cnr.it

\section{CURATORI DEL VOLUME}

Attilio Sulli, Silvia Ceramicola, Fabiano Gamberi, Maria Rosaria Senatore, Francesco L. Chiocci, Francesca Budillon.

Papers, data, figures, maps and any other material published are covered by the copyright own by the Società Geologica Italiana.

DISCLAIMER: The Società Geologica Italiana, the Editors are not responsible for the ideas, opinions, and contents of the papers published; the authors of each paper are responsible for the ideas opinions and contents published.

La Società Geologica Italiana, $i$ curatori scientifici non sono responsabili delle opinioni espresse e delle affermazioni pubblicate negli articoli: l'autore/i èlsono illi solo/i responsabile/i. 
Agate M., Sprovieri M., Passaro S., Tamburrino S., Sulli A.,Vallefuoco M., Giaramita L., Placenti F., Polizzi S., Lo Iacono C., Incarbona A. \& Butera F. - Late Quaternary sedimentary complexes along the Marettimo Valley (Egadi Islands, western Sicily offshore).

Alberico I., Budillon F., Casalbore D., Di Fiore V. \& Iavarone R. - Il ruolo dell'integrazione dei dati nella definizione degli scenari di pericolosità da tsunami. Il caso studio della città di Napoli......

Angeletti L., Argnani A., Foglini F. \& Taviani M. - Slump scars, corals and a chimney forest: The new geomorphological map of the Montenegrin slope.

Bortoluzzi G., Giglio F., Ligi M., Del Bianco F., Ferrante V., Gasperini L. \& Ravaioli M. - Morphobathymetry of Boka Kotorska Bay

Bracchi V.A., Basso D., Savini A., Malinverno E. \& Corselli C. - Ridges di origine problematica sul Plateau di Malta (Canale di Sicilia, Italia).

Buongiorno Nardelli B., Budillon F., Watteaux R., Ciccone F., Conforti A., De Falco G., Di Martino G., Innangi S., Tonielli R. \& Iudicone D. - Plumes turbolenti e formazione di pockmarks in seeps attivi da sorgenti sottomarine

Cavallaro D., Coltelli M.1 \& Firetto Carlino M. - Evidenze di faglie attive che dislocano la prosecuzione in mare di colate laviche storiche etnee

Chiocci F.L., Alonso B., Casalbore D., Ceccarelli E.M., Estrada F., Gross F., Georgiou P., Pampides I., Mantopoulos P., Magrini L.C., Maisto F., Migeon S., Morfis I., Panagiotopoulos I., Patanè R.A., Pierdomenico M., Rousakis G., Sposato A., Schulze I., Sakellariou D. \& Zavitsanou A. - Risultati preliminari della campagna EUROFLEETS2 LGT - AMORGOS - 56 per lo studio del più grande maremoto del XX secolo nel Mediterraneo orientale.

Coren F., Codiglia R. \& Zgur F. - Il panorama delle infrastrutture navali da ricerca italiane dopo il refitting della SPS N/R OGS Explora

Crocitti M., Sulpizio R., Insinga D.D., De Rosa R., Donato P., Iorio M., Zanchetta G., Barca D. \& Lubritto C. - Ash dispersal from Holocene and Late Pleistocene eruptions of Italian volcanoes: the marine record as an archive of moderately explosive volcanic eruptions.

Crupi A., Lanza S. \& Randazzo G. - First data on coastal monitoring, using both photogrammetry and lidar 3D laser mapping from uav surveys to apply in the coastal management of the strait of Messina (Capo Peloro)

Cultrera F, Barreca G., Burrato P., Ferranti L., Monaco C., Passaro S., Pepe F. \& Scarfi L. - Active faulting and continental slope instability in the Gulf of Patti (Tyrrhenian side of NE Sicily, Italy):a field, marine and seismological joint analysis.

Dalla Valle G. \& Gamberi F. - Evoluzione di canali torbiditici lungo la scarpata continentale del margine Campano (Mar Tirreno)

Dalla Valle G., Pellegrini C., Gamberi F., Foglini F., Campiani E., Rovere M., Maselli V. \& Trincardi F. Il margine continentale Sud Adriatico: sistemi deposizionali, processi oceanografici e fenomeni di instabilità

De Falco G., Conforti A., Pascucci V., Sanna I., Del Vais C., Gasperini L. \& Stanghellini G - Evolution of coastal systems related to historic Phoenician-Punic centres in the Gulf of Oristano (western Sardinia) ...........

Demarte M. - Sistemi innovativi REA (Rapid Environmental Assessment) per la mappatura dei fondali.........

Di Blasi F. \& Gamberi F. - Influenza dei fattori allogenici e autogenici sui processi erosivi caratterizzanti i sistemi torbiditici: un esempio dal sistema torbiditico di capo ferrata (margine orientale Sardo)

Di Rita F., Margaritelli G., Lirer F., Bonomo S., Cascella A., Insinga D.D., Petrosino P., Florindo F., Lurcock P. C., Vallefuoco M., Rettori R., Ferraro L. \& Magri D. - Late Holocene vegetation and climate changes recorded by a high resolution marine record from the Gulf of Gaeta (central Italy)

Distefano S., Gallerani A., Leidi E., Mercorella A., Rovere M., Di Stefano A. \& Gamberi F. - Caratterizzazione geomorfologica della piattaforma continentale NE della Sicilia attraverso l'interpretazione di dati Multibeam e di profili sismici Chirp.

Filippone M., Tessarolo C., Ciaccio G., Corrias N., Nemola A., Sorce R., Cocchi L. \& Di Grigoli G. - Indagini Magnetometriche ad Alta Risoluzione: Approcci Industriali 
Firetto Carlino M., Coltelli M., Cavallaro D., Zgur F. \& Patanè D. - Evidenze di tettonica trascorrente nell'offshore etneo identificate sulla base di nuovi dati di sismica a riflessione multicanale

Gasperini L., Polonia A., Bortoluzzi G., Ferrante V. \& Çağatay N. - Earthquake Geology in the Sea of Marmara

Giustiniani M. \& Tinivella U. - Contributo per lo studio di aree estreme: un esempio di modelling nelle regioni polari.

Iannaccone G., De Martino P., Guardato S., Donnarumma G.P., Martino C., Chierici F. \& Beranzoli L. - Il sistema di monitoraggio marino dei Campi Flegrei (MEDUSA): nuovi dati e nuove prospettive per la geodesia marina

Ingrassia M., Martorelli E., Italiano F., Macelloni L., Bosman A., Conte A.M., Di Bella L., Frezza V., Sposato A. \& Chiocci F.L. - Il sistema idrotermale al largo dell'Isola di Zannone (Mar Tirreno centrale): nuovi risultati e prospettive

Innangi S., Tonielli R., Di Martino G. \& Giardina F. - Classificazione automatica con RSOBIA (Remotely Sensing Object Based Image Analysis) per la realizzazione della mappa dei fondali dell'Isola di Linosa

Ivaldi R. \& Sinapi L. - L’Istituto Idrografico della Marina e lo SCUFN (Sub-Committee on Undersea Feature Names)

Loreto M.F., Pagnoni G., Pettenati F., Armigliato A., Tinti S., Sandron D., Brutto F., Muto F., Facchin L. \& Zgur F. - Scenari sismico e di tsunami del terremoto del 1905 (Calabria Occ., Tirreno SE) come strumento di analisi del rischio

Maesano F.E., Tiberti M.M. \& Basili R. - Three-dimensional modelling of the Calabrian Subduction Interface.....

Maisto F. \& Chiocci F.L. - Architettura stratigrafico-sequenziale delle sequenze deposizionali quaternarie lungo il margine tirrenico da La Spezia all'Argentario

Margaritelli G., Cacho I., Català A., Rettori R., Bonomo S., Cascella A. \& Lirer F. - Sea surface temperature reconstruction over the last five millennia in the Sicily Channel (central Mediterranean): $\mathrm{Mg} / \mathrm{Ca}$ ratio from planktonic foraminifer Globigerinoides ruber.....

Meccariello M., Ferranti L., Barreca G. \& Palano M. - New insights on the tectonics of the Lampedusa Plateau from the integration of offshore, on-land and space geodetic data.

Meccariello M., Ferranti L. \& Pepe F. - Crustal deformation and active tectonics in the NW Sicily Channel based on multi-scale analysis of seismic reflection profiles .

Misuraca M., Budillon F., Cosentino D., Ferraro L., Tonielli R., Di Martino G. \& Innangi S. - Migrazioni e fuoriuscite di fluidi lungo la piattaforma campana settentrionale: osservazioni su profili Chirp e Sparker

Moriconi R., Clare M. \& Lo Iacono C. - Mappatura a risoluzione sub-metrica e analisi morfometrica di fenomeni di instabilità gravitativa lungo la scarpata meridionale della Sardegna (Mediterraneo Occidentale) .....

Nonnis O., Paganelli D., Pazzini A. \& Proietti R. - Effetti del dragaggio di sabbie relitte sui sedimenti superficiali: casi di studio nella piattaforma laziale.

Palmiotto C., Ligi M. \& Bonatti E. - Geodinamica della trasforme San Paolo nell'Atlantico equatoriale........

Palmiotto C., Loreto M.F., D’Angelo S. \& Fiorentino A. - Un'immagine morfotettonica a scala regionale del bacino di retroarco Tirrenico (Mar Mediterraneo)

Pellegrini C., Asioli A., Bohacs K.M., Drexler T.M., Sweet M.L., Maselli V., Gamberi F., Rovere M., Dalla Valle G. \& Trincardi F. - Come si forma un delta di stazionamento basso? Stratigrafia e paleoambienti del Delta del Po durante l'ultimo massimo glaciale e implicazioni per lo studio di successioni antiche

Pepe F., Di Donato V., Faraci C., Molisso F., Dera R., Ferranti L., Insinga D.D., Sacchi M. \& Passaro S. - Stratigraphy of upper Quaternary contourite drifts and paleoceanographic modeling of the Gulf of Taranto (Ionian Sea, Southern Italy).

Pierdomenico M., Casalbore D., Cardone F., Carluccio A., Di Bella L., Frezza V., D’Onghia G. \& Chiocci F.L. - Distribuzione di rifiuti antropici lungo alcuni canyon sottomarini prospicienti le coste italiane: il ruolo dei processi sedimentari e gli impatti sulla fauna marina profonda 
Polonia A., Nelson C.H., Romano S., Vaiani S., Torelli L., Colizza E., Gasperini L., Gasparotto G., Artoni A. \& Miserocchi S. - The AD 1908 Messina earthquake and tsunami: causative fault and co-seismic slope failures in the Ionian Sea

Romagnoli C., Casalbore D., Ricchi A., Lucchi F., Quartau R., Bosman A., Tranne C.A., Adami C. \& Chiocci F.L. - The contribution of marine geological studies to reconstruct the Late-Quaternary evolution of Salina Island (Aeolian archipelago)

Ruberti D., Pepe F., Sacchi M. \& Vigliotti M. - Evoluzione Olocenica e Recente della Piana costiera del fiume Volturno

Sakellariou D., Chiocci F.L., Casalbore D., Ercilla G., Casas D., Pierdomenico M., Lindhorst K., Maisto F., Kelner M., Zavitsanou A., Pavlidi-Palla M.1 \& Manta K. - Preliminary results of the EUROFLEETS2 LGT-GIOIA-77 cruise: Unravelling the complex dynamics of a human-induced landslide which generated the Gioia 1977 tsunami ....

Sañé E., Martorelli E. \& Chiocci F.L. - Rodoliti e facies acustiche sonar: il caso di studio dell'Arcipelago Pontino Occidentale, Mar Mediterraneo

Sanfilippo R., Guido A., Rosso A., Belmonte G., Gerovasileiou V., Jimenez C., Hadjioannou L., Achilleos K., Russo F., Kupryianova E. \& Mastandrea A. - Le grotte sottomarine del Mediterraneo: peculiarità geobiologiche di un habitat prioritario

Senatore M.R., Meo A., Falco M., Insinga D.D., Petrosino P., Di donato V., Aiello G. \& Iorio M. - Il Tufo Giallo Napoletano nell'architettura stratigrafica del Golfo di Gaeta (Tirreno Meridionale): nuovi dati sismostratigrafici e tefrostratigrafici

Simeone S. \& De Falco G. - BioGeomorphological control along Mediterranean Beaches

Sinapi L. \& Demarte M. - Idrografia e Maritime Capacity Building

Sulli A., Albano L. \& Zizzo E. - Analisi comparata di metodi di calcolo del run-up per tsunami generati da frana.Casi di studio nel Margine Continentale della Sicilia Settentrionale

Taliana D. \& Cecchini S. - Marine Surveys for industry in challenging environments

Tesi T., Asioli A. , Minisini D., Maselli V., Dalla Valle G., Gamberi F., Langone L., Cattaneo A., Montagna P. \& Trincardi F. - Ricostruzione del forzante termoalino durante la formazione del sapropel S

Tessarolo C., Ciaccio G., Corrias N., Nemola A., Sorce R. \& Di Grigoli G. - Interazioni Terra-Mare e Hazard. Conservazione delle strutture antropiche e riqualificazione Ambientale: un caso studio

Tonielli R., Innangi S., Di Martino G. \& Giardina F. - Nuovi risultati delle indagini geofisiche sull'Isola di Linosa

Tramontana M., Baioni D. \& Savelli D. - Depositi di frana e colata sottomarina nel bacino della corsica (mar tirreno)

Valenzano E., Scardino G., Cipriano G., Fago P., Capolongo D., De Giosa F., Lisco S., Mastronuzzi G. \& Moretti M. - Ricostruzione della superficie erosiva dell'ultimo massimo glaciale nell'area del Mar Piccolo (Taranto)

Volpi V., Delben A., Civile D. \& Zgur F. - Neogene tectono-sedimentary interaction between the calabrian accretionary wedge and the apulian foreland in the northern ionian sea.

Zizzo E., Sulli A. \& Morticelli M.G. - Sismotettonica del Margine Continentale della Sicilia nord-occidentale: implicazioni per la valutazione del geohazard

Zizzo E., Sulli A., Agate M., Lo Iacono C. \& Spatola D. - Caratterizzazione e Habitat mapping del Coralligeno di piattaforma lungo il margine continentale della Sicilia nord-occidentale

Authors' Index 


\title{
Late Quaternary sedimentary complexes along the Marettimo Valley (Egadi Islands, western Sicily offshore)
}

\author{
Agate M. ${ }^{1}$, Sprovieri M. ${ }^{2}$, Passaro S. ${ }^{3}$, Tamburrino S. ${ }^{2,}$, Sulli A. ${ }^{1}$,Vallefuoco M. ${ }^{3}$, Giaramita L. ${ }^{2}$, \\ Placenti F. ${ }^{2}$, Polizzi S. ${ }^{1}$, Lo Iacono C. ${ }^{4}$, Incarbona A. ${ }^{1} \&$ Butera F. ${ }^{1}$ \\ ${ }^{1}$ Dipartimento di Scienze della Terra e del Mare, Università di Palermo. \\ ${ }^{2}$ Istituto per l'Ambiente Marino Costiero CNR, Campobello di Mazara, Trapani. \\ ${ }^{3}$ Istituto per l'Ambiente Marino Costiero CNR, Napoli. \\ ${ }^{4}$ National Oceanography Centre, Southampton, United Kingdom.
}

Corresponding author email: mauro.agate@unipa.it

Keywords: Contourite drifts, Egadi Island, Late Quaternary, Prograding depositional systems.

Across the Egadi Island archipelago (western Sicily offshore), the Marettimo Valley is located at shallow to intermediate water depths $(150-450 \mathrm{~m})$ and it is crossed by bottom current probably related to Levantine Intermediate Water that clockwise flows around Sicily island. The Valley is about $30 \mathrm{~km}$ long, has a minimum width of $1.8 \mathrm{~km}$ between the continental shelf edges of Marettimo island and Favignana island, and displays both depositional and erosional settings. Erosional settings are mostly centered in the central sector of the Valley where lower Quaternary as well as pre-Quaternary rocks outcrop on the sea floor.

On the peripheral sectors of the Valley, late Quaternary progradational complexes accumulated along both eastern and western flanks. South-west of the Favignana island, these progradational complexes, investigated by means of high resolution seismic profiles and also mapped using multibeam morpho-batymetric data, consists of two types of seismic facies units: - unit A displays reflection-free seismic facies and thin, low- amplitude, inclined reflectors with downlap terminations onto the lower boundary, and erosional truncation at the upper boundary; these seismic facies are referable to oblique-tangential clinoforms displaying variable height and wedge-shaped external geometry; -unit B shows continuous, parallel, slightly concave reflectors and, towards the central sector of the Valley, continuous, sub-horizontal reflectors that form a deposit having a very broad low-mounded geometry; lateral transition in between concave and sub-horizontal reflectors is characterized by channelized erosional truncations; landwards, this unit wedge-out with onlap lateral termination on the offsets of the clinoformed wedges. Top wards, these latter are topped by an erosional transgressive surface formed during the last eustatic sea-level rise, locally covered by Holocene deposits.

The prograding sedimentary complex detected along the south-western Favignana offshore continuously extend for about $15 \mathrm{~km}$; smaller progradational complexes have been recognized also in the norther sector of the valley and, scattered, along the western flank (Marettimo Island continental shelf margin).

According to our seismo-stratigraphic analysis, the two very different seismic facies units represent two distinct sedimentary deposits: - unit A accumulated by progradation of shallow-water deposits during eustatic forced-regression; unit B is referable to contourite drifts deposited by bottom currents through the Marettimo Valley.

Mutual interaction can be envisaged between progradational growth of the margin and contourite accumulation: progradation progressively reduces the width of the Marettimo valley producing acceleration of bottom current inside; contourite deposition creates a landward gradient of the depositional ramp forcing a decrease of the clinoforms height and, with constant sedimentary supply, an increase of the progradation rate. 


\title{
Il ruolo dell'integrazione dei dati nella definizione degli scenari di pericolosità da tsunami. Il caso studio della città di Napoli
}

\author{
Alberico I. ${ }^{1}$, Budillon F. ${ }^{1}$, Casalbore D. ${ }^{2}$, Di Fiore V. ${ }^{1}$ \& Iavarone R. ${ }^{3}$ \\ ${ }^{1}$ Istituto per l'Ambiente Marino Costiero CNR, Napoli. \\ ${ }^{2}$ Dipartimento di Scienze della Terra, Sapienza Università di Roma. \\ ${ }^{3}$ Istituto di Biologia Agro-Ambientale e Forestale CNR, Napoli.
}

\section{Corresponding author email: ines.alberico@cnr.it}

Keywords: Tsunami hazard, Tsunami multi-scenario, Golfo di Napoli.

I recenti tsunami (Papua Nuova Guinea nel 1998, Sumatra nel 2004 e Giappone nel 2011) e la densa urbanizzazione delle zone costiere hanno sollecitato la comunità scientifica a sviluppare modelli in grado di identificare le aree potenzialmente esposte a inondazione.

Nel presente lavoro è stato adottato l'approccio multi-scenario (IPCC, 2007; Tinti et al., 2008) per valutare la pericolosità da tsunami per la città di Napoli. A tal fine sono stati integrati i dati degli open database, della letteratura scientifica e della morfometria delle nicchie di frane sottomarine del margine campano per identificare alcuni parametri, come l'altezza d'acqua ed i tempi di propagazione, degli eventi potenzialmente pericolosi per la città di Napoli, utili per una pianificazione attenta alle pericolosità naturali.

Eventi sismici con magnitudo tra 6 e $7 \mathrm{Mw}$ e origine nel Mediterraneo occidentale (far field) sono potenzialmente pericolosi per la città di Napoli. Tali eventi potrebbero innescare tsunami che in circa 30' potrebbero giungere nel Golfo di Napoli, con un'altezza d'acqua fino a $0,5 \mathrm{~m}$. Anche i fenomeni gravitativi che coinvolgono i fianchi emersi degli edifici vulcanici eoliani potrebbero rappresentare una fonte di pericolosità per la città di Napoli, dato che l'evento avvenuto a Stromboli nel Dicembre 2002, per quanto di dimensioni limitate, ha causato lungo la costa campana un primo ritiro del mare di 10-12 m seguito da una inondazione di 60-70 m (Maramai et al., 2005). Nel near field, quelli innescabili dall'attività dei vulcani campani rappresentano la principale causa d'allerta. Nei documenti storici sono riportati eventi con altezze d'acqua variabili da pochi centimetri $(30-40 \mathrm{~cm})$ a qualche metro $(1.8-4.5 \mathrm{~m})$. Nell'attuale fase di quiescenza vulcanica, l'attività sismica dei vulcani napoletani, sebbene generalmente di magnitudo inferiore a $4 \mathrm{Mw}$, potrebbe innescare tsunami da eventi a cascata. Infine, sebbene l'analisi morfometrica abbia evidenziato la suscettibilità del margine sommerso all'instabilità gravitativa, solo poche frane tra le Isole Pontine ed il Golfo di Salerno sono risultate potenzialmente tsunamigeniche, con stime dell'altezza d'acqua lungo costa di pochi metri (Alberico et al., 2018).

Gli scenari di pericolosità consentono di fornire ai pianificatori gli strumenti per potenziare, sul lungo periodo, la resilienza delle città.

\section{References:}

AIberico I. et alii (2018) - A critical review of potential tsunamigenic sources as first step towards the tsunami hazard assessment for the Napoli Gulf (Southern Italy) highly populated area, Natural Hazard, 92, 43-76.

IPCC (2007) - Climate Change 2007: Mitigation. Contribution of Working Group III to the Fourth Assessment Report of the Intergovernmental Panel on Climate Change.

Maramai A. et alii (2005) - Near-and far-field survey report of the 30 December 2002 Stromboli (Southern Italy) tsunami, Mar. Geol., 215, 93-106.

Tinti S. et alii (2008) - Stromboli Island (Italy): scenarios of tsunamis generated by submarine landslides. In: Pure Appl Geophys, 165, 2143-2167. 


\title{
Slump scars, corals and a chimney forest: The new geomorphological map of the Montenegrin slope
}

\author{
Angeletti L. ${ }^{1}$ Argnani A. ${ }^{1}$, Foglini F. ${ }^{1} \&$ Taviani M. ${ }^{1}$ \\ ${ }^{1}$ Istituto di Scienze Marine CNR, Bologna.
}

Corresponding author email: lorenzo.angeletti@ismar.cnr.it

Keywords: Cold-water corals, Fossil chimneys, Multibeam bathymetry, Southern Adriatic basin, Submarine landslides.

The Montenegrine submarine slope is a segment of the eastern slope of the Southern Adriatic Sea that represents the current foredeep basin of the Dinaride-Hellenide fold-and-thrust belt (Argnani et alii, 1996; Argnani, 2013).

In this part of the Adriatic Sea the shelf is rather wide, 10 to $40 \mathrm{~km}$, with the shelf break that trends roughly north-northwest and is at about $400 \mathrm{~m}$ water depth. The morphology of the Montenegrine slope has been investigated using a high-resolution multibeam bathymetry, which shows that the slope is carved by a set of closely spaced canyons that only in few instances scratch the shelf break. No drainage system connected to the slope canyons is visible on the shelf, and the canyons' development appears to be strongly governed by the coalescence of multiple landslide scars (Argnani et alii, 2011). The high spatial density along the slope of incised canyons suggests a rather high maturity of the drainage system, characterizing a destructive-type slope dominated by mass wasting (Galloway, 1998).

A field of fossil chimneys has been exposed by erosion at the seafloor in the head of one of the southernmost canyons (Angeletti et al., 2015). The stable carbon isotope geochemistry indicates that the chimneys were formed in response to hydrocarbon fluid seepage (Angeletti et al., 2015). Not far from the fossil chimneys a small field of pockmarks is present at the shelf edge, located in an intra-canyon position, where the canyon headscarps are incising the shelf break. The occurrence in this area of chimneys and pockmarks suggests that focussed fluid flow systems (Berndt, 2005) can have played a role in destabilizing the slope sediments.

Standing and abated chimneys, their rubble and other hardgrounds are habitat to relevant sessile spongecnidarian megabenthos, which also includes the highly-emblematic cold water corals Madrepora oculata, Lophelia pertusa, and Desmophyllum dianthus (Angeletti et alii, 2014).

\section{References:}

Angeletti L. et alii (2014) - New deep-water cnidarian sites in the southern Adriatic Sea. In: Medit. Mar., Sci. 15, $263-273$. Angeletti L. et alii (2015) - The "chimney forest" of the deep Montenegrin margin, south-eastern Adriatic Sea. In: Mar. Petr. Geol., 66, 542-554.

Argnani A. et alii (1996) - Tettonica dell'Adriatico meridionale. Mem. Soc. Geol. It., 51, 227-237.

Argnani A. et alii (2011) - The eastern slope of the southern Adriatic basin: a case study of submarine landslide characterization and tsunamigenic potential assessment. Mar. Geoph. Res., 32, 299-311.

Argnani A. (2013) - The influence of Mesozoic palaeogeography on the variations in structural style along the front of the Albanide thrust-and-fold belt. Ital. J. Geosci., 132, 175-185.

Berndt C. (2005) - Focussed fluid flow in passive margin continental margins. Phil. Trans. Royal Soc., A, 363, $2855-2871$.

Galloway W.E. (1998) - Siliciclastic Slope and Base-of-Slope Depositional systems: component facies, stratigraphic architecture, and classification. AAPG Bull., 82, 569-595. 


\title{
Morphobathymetry of Boka Kotorska Bay
}

\author{
Bortoluzzi G. ${ }^{1}$, Giglio F. ${ }^{1}$, Ligi M. ${ }^{1}$, Del Bianco F. ${ }^{1,}$, Ferrante V. ${ }^{1}$, Gasperini L. ${ }^{1}$ \& Ravaioli M. ${ }^{1}$ \\ ${ }^{1}$ Istituto Scienze Marine CNR, Bologna. \\ ${ }^{2}$ Proambiente Scrl, Bologna.
}

Corresponding author email: marco.ligi@ismar.cnr.it

Keywords: Boka Kotorska Bay, Karst environment, Morphology, Multibeam bathymetry, Sub-bottom profiles.

Littoral morphology results worldwide from the interaction between climate, sealevel changes, erosion, sedimentation and tectonics. Several examples of transitional areas can be found in the eastern border of the Adriatic Sea, characterized by fragmented coastlines, islands, coastal bays. Bays and estuaries interact with the main basin influencing it and being influenced by it in terms of circulation patterns and freshwater supply. One of the most intriguing feature along the entire Adriatic coast is the bay of Boka Kotorska, where the sea enters inland for over $20 \mathrm{~km}$. The Bay is located in the southeastern Adriatic Sea along the Montenegro margin, and is surrounded by high mountains that are part of the Dinaric range. For this reason, the Bay is improperly considered as the southernmost fjord in Europe, although its origin is not related to glacial processes. In fact, Boka Kotorska Bay is part of a ria coastal system (Frankl et al., 2016), where the valleys were formed mainly during the Messinian Salinity Crisis, when the Mediterranean Sea was nearly completely dry allowing regressive erosion of the landscape. However, despite its historical and geostrategic role since the pre-roman Illyrian thalasocracy, the morphobathymetry and geology of the Bay is poorly known.

High-resolution geophysical data collected during several scientific cruises between 2008 and 2013, reveal unknown details of seafloor morphology and sedimentary infilling geometry of the Bay (Bortoluzzi et al., 2016). Multibeam bathymetry combined with analysis of seismic reflection images suggests that the observed morphologies are due to the interaction at different timescales of climate, water circulation, sealevel changes, erosion, sedimentation and tectonics. In fact, a major role is played by tectonic deformations, in a region prone to large magnitude earthquakes.

The Bay is composed by three major basins (Herceg Novi, Tivat and Morinj-Risan-Kotor), connected by two narrow straits (Kumbor and Verige) with a maximum depth of $67 \mathrm{~m}$. It shows steep upper slopes and flat sub-basin central sectors lying at depths ranging from 35 to $45 \mathrm{~m}$. Among various morphologies shaping the seafloor, we note the presence of: deeply incised valleys and delta fans related to past sealevel falls; slope failures and mass wasting triggered by strong earthquakes; channels bounding the steep slopes of Kumbor and Verige narrow passages, and sediment wave fields in Verige Strait formed by strong bottom currents; karst morphologies developing at seafloor with submarine siphons, springs and resurgences (pockmarks) fed by karst hydrology of Boka Kotorska Bay's surroundings.

\section{References:}

Bortoluzzi G. et alii (2016) - Morphobathymetry of Boka Kotorska Bay. In: Joksimovic A. (ed), The Boka Kotorska Bay Environment, Springer, Switzerland, doi: 10.1007/698_2016_29.

Frankl A. et alii (2016) - The regional geomorphology of Montenegro mapped using land surface parameters. In: Zeitschrift für Geomorphologie, 60, 1:1-14. 


\title{
Ridges di origine problematica sul Plateau di Malta (Canale di Sicilia, Italia)
}

\author{
Bracchi V.A., Basso D., Savini A., Malinverno E. \& Corselli C. \\ Dipartimento di Scienze dell'Ambiente e della Terra, \\ Consorzio Nazionale Interuniversitario per le Scienze del Mare, Unità Locale di Ricerca Università di Milano-Bicocca. \\ Corresponding author email: valentina.bracchi@unimib.it
}

Keywords: Coralligeno, Molluschi, MIS 6, Pleistocene.

Nel settore occidentale del Plateau di Malta (Sicilia) sono stati rilevati vulcani di fango quiescenti e ridges, legati alla fuoriuscita di fluidi dal fondo (Savini et alii, 2009). Rilievi geofisici validati tramite filmati video hanno permesso di descriverne alcuni aspetti litologici, stratigrafici e biologici (Savini et alii, 2009). Lo studio multidisciplinare (sedimentologia, paleontologia, datazioni U/Th) di due carote di sedimento prelevate all'interno di un ridge, ha permesso di indagare la natura e l'origine di queste morfologie.

Le due carote sono GC01, sul fianco del ridge, $141 \mathrm{~m}, 176 \mathrm{~cm}$; GC02, al top del ridge, $144 \mathrm{~m}, 81 \mathrm{~cm}$.

Sono stati identificati 2582 esemplari di molluschi e brachiopodi appartenenti a 209 specie per la carota GC01, 1388 esemplari appartenenti a 128 specie per la carota GC02. Entrambe le carote sono costituite da una frazione fangosa al top, con specie indicative di biocenosi circalitorali come DC, VTC e VP. Spostandosi verso la base di entrambe le carote aumenta la frazione sabbiosa, fino alla comparsa di un livello biocostruito. In corrispondenza del livello sabbioso sono presenti specie mistofile e psefofile, mentre il substrato duro alla base delle carote si accompagna alla comparsa di specie associate alla biocenosi del Coralligeno, insieme ad esemplari ben conservati appartenenti a specie di ambienti infralitorali, legati a biocenosi come HP e AP. La biocostruzione è massiva e densa, dominata da alghe coralline tra cui Lithophyllum stictaeforme, Titanoderma pustulatum, quantitativamente dominanti.

Nell'intervallo 132-156 cm della carota GC01, la biocostruzione è sostituita da ghiaia e ciottoli di natura silicoclastica e biogenica, questi ultimi con una conservazione molto variabile. Alcuni frammenti presentano una patina nera, lucida, sulla cui superficie sono state rinvenute sferule framboidali di FeS. Analisi puntiformi EDS hanno mostrato la presenza di $\mathrm{CaSO}_{4}$, silicati di $\mathrm{Al} \mathrm{e} \mathrm{Mg}$. L'associazione bentonica associata è rappresentata da $65 \%$ di specie connesse a biocenosi infralitorali come HP e AP.

La porzione basale della carota GC01 è attribuibile al MIS 6, in accordo con le interpretazioni suggerite dalla stratigrafia sismica e biostratigrafica (Savini et alii, 2009).

Le carote hanno registrato una trasgressione marina. La biocostruzione rinvenuta alla base è assimilabile alla biocostruzione coralligena attuale. Essendo un elemento morfologico tridimensionale del paesaggio sottomarino, contribuì attivamente alla formazione del ridge nel passato.

\section{References:}

Savini A., Malinverno E. et alii (2009) - Shallow seep-related seafloor features along the Malta plateau (Sicily channel - Mediterranean Sea): Morphologies and geo-environmental control of their distribution. Marine and Petroleum Geology, 26: 1831-1848. 


\title{
Plumes turbolenti e formazione di pockmarks in seeps attivi da sorgenti sottomarine
}

\author{
Buongiorno Nardelli B. ${ }^{1,2}$, Budillon F. ${ }^{1}$, Watteaux R. ${ }^{3}$, Ciccone F. ${ }^{1,4}$, Conforti A. ${ }^{1}$, De Falco G. ${ }^{1}$, \\ Di Martino G. ${ }^{1}$, Innangi S. ${ }^{1}$, Tonielli R. ${ }^{1}$ \& Iudicone D. ${ }^{3}$ \\ ${ }^{1}$ Istituto per l'Ambiente Marino Costiero CNR, Oristano. \\ ${ }^{2}$ Istituto di Scienze dell'Atmosfera e del Clima CNR, Roma. \\ ${ }^{3}$ Stazione Zoologica Anton Dohrn, Napoli. \\ ${ }^{4}$ Istituto Nazionale di Oceanografia e di Geofisica Sperimentale, Trieste.
}

Corresponding author email: bruno.buongiornonardelli@,cnr.it

Keywords: Golfo di Policastro, Risalite di fluidi, Sorgenti sottomarine, Submarine Groundwater Discharge.

L'apporto di acqua di origine continentale attraverso risorgive a fondo mare, definito come Submarine Groundwater Discharge (SGD), sebbene documentato da secoli, è stato solo recentemente riconosciuto come parte non trascurabile nel budget idrologico e in grado di condizionare la componente fisico-chimica e biologica dei mari e degli oceani in aree costiere. Indipendentemente dalla specifica natura del sistema idrico (perenne, stagionale, episodico) e dalle caratteristiche fisico-chimiche delle acque, una SGD è generalmente caratterizzata da più punti di emissione più o meno ravvicinati e da flussi limitati (Fleury et al., 2009), in specchi di mare anche fino a $-100 \mathrm{~m}$; ciò rende l'identificazione ed il campionamento delle emissioni di difficile realizzazione. Questo è uno dei motivi per i quali le sorgenti sottomarine sono fin ora state trascurate come obiettivo scientifico e spesso non considerate nella gestione delle risorse idriche. Recentemente, Rodellas et al (2015) hanno dimostrato che in Mediterraneo le SDG rappresentano una larga parte del volume di acque dolci, quasi al pari del contributo fluviale ed una fonte rilevante di nitrati, fosfati e silicati in Mediterraneo, con impatti considerevoli nella capacità produttiva primaria in condizioni oligotrofiche.

In questo lavoro si analizzano i dati acquisiti durante la campagna ARCOSE (N/O Urania, settembre 2010) in corrispondenza di un campo di pockmarks nel Golfo di Policastro (Tirreno meridionale), che rappresenta l'evidenza morfologica di una sorgente sottomarina (Allocca et al., 2007): profili CTD (ossigeno disciolto, fluorescenza, temperatura, conducibilità, densità), linee sismiche e dati batimorfologici (DEM batimetrico di alta risoluzione, $20 \mathrm{~cm} \times 20 \mathrm{~cm}$ ), costituiscono il dataset in base al quale sono state identificate le zone di risalita dei fluidi nel sottofondo e gli effetti della turbolenza dei plumes sulla colonna d'acqua e al fondo mare. Le osservazioni ed il modello analitico sviluppato danno una prima descrizione della complessità dei processi di mescolamento nella colonna d'acqua indotti dalle plumes in aree di piattaforma e l'interazione al fondo mare, che origina la formazione, il mantenimento nel tempo dei pockmarks e probabilmente ne determina le dimensioni (Buongiorno Nardelli et al., 2017). Il sistema osservato è un laboratorio naturale per misurazioni in situ sulla risospensione, trasporto e decantazione dei sedimenti in condizioni di seeps attivi.

\section{References:}

Allocca V. et alii (2007) - Note illustrative della Carta Idrogeologica dell'Italia meridionale. In: Istituto Poligrafico e Zecca dello Stato, Roma: 1-211, ISBN88-48-0215-5.

Buongiorno Nardelli B. et alii (2017) - Pockmark morphology and turbulent buoyant plumes at a submarine spring. Continental Shelf Research, 148, 19-36.

Fleury P. et alii (2007) - Submarine springs and coastal karst aquifers: a review.Journal of Hydrology, 339: 79- 92.

Rodellas V. et alii (2015) - Submarine groundwater discharge as a major source of nutrients to the Mediterranean Sea. In: PNAS, 112,13: 3926-3930. 


\title{
Evidenze di faglie attive che dislocano la prosecuzione in mare di colate laviche storiche etnee
}

\author{
Cavallaro D. ${ }^{1}$, Coltelli M. ${ }^{1} \&$ Firetto Carlino M. ${ }^{1,2}$ \\ ${ }^{1}$ Istituto Nazionale di Geofisica e Vulcanologia, Osservatorio Etneo, Catania. \\ ${ }^{2}$ Istituto Nazionale di Oceanografia e Geofisica Sperimentale, Trieste.
}

Corresponding author email: mauro.coltelli@ingv.it

Keywords: Colate laviche subacquee, Dati batimetrici multibeam, Etna, rilievo geologico subacqueo, Tettonica recente.

Dati batimetrici multibeam acquisiti nell'offshore dell'Etna (Chiocci et al., 2011) hanno permesso di caratterizzare morfologicamente i fronti sommersi delle colate laviche storiche di Mt Ilice e Mt Gorna (datate rispettivamente $1030 \pm 40$ d.C. e 396 a.C., Tanguy et al., 2012), che si estendono per $10 \mathrm{~km}$ lungo il fianco E del vulcano fino alla costa a S di Pozzillo (Branca et al., 2011). L'analisi morfo-batimetrica è stata integrata da rilievi geologici subacquei, realizzati mediante immersioni, per acquisire foto, campionare rocce ed eseguire misure di rigetti, distanze e temperatura dell'acqua.

Il fronte sommerso della colata di Mt Ilice, che si estende per $250 \mathrm{~m}$ a largo di Pozzillo con spessori fino a $50 \mathrm{~m}$, appare dislocato da una scarpata di faglia di dip-slip orientata N-S, con rigetti massimi di $5 \mathrm{~m}$. Lungo lo specchio di faglia sono stati identificati: strie cinematiche sub-verticali, due gradini morfologici alti $50-70 \mathrm{~cm}$, una diminuzione progressiva degli organismi incrostanti verso il basso e variazioni di temperatura dell'acqua associabili a venute d'acqua dolce. Tali dati e l'età della colata, indicano un'attività recente della faglia (tassi di dislocazione verticale di $0.5 \mathrm{~cm} / \mathrm{a}$ ), correlabile con dislocazioni cosismiche di eventi locali come quello del 30/4/1981 (intensità MSK=VI, Azzaro, 1999), che generò fratturazioni a Pozzillo e un'onda di maremoto di 1 $\mathrm{m}$ nel vicino porto (Patanè e Imposa, 1995), suggerendo un epicentro nell'immediato offshore.

Il fronte della colata di Mt Gorna si estende per $400 \mathrm{~m}$ dalla costa ed è dislocato da una scarpata orientata $\mathrm{N}-\mathrm{S}$, prosecuzione in mare della faglia di S. Leonardello, una tra le più note strutture sismogenetiche etnee (es. terremoti del 1920, 1950 e 1989 - MSK=VII-VIII, Azzaro, 1999). L'età della colata ed il rigetto (fino a 10 m) lungo il suo fronte sommerso indicano tassi di dislocazione verticale di $0.42 \mathrm{~cm} / \mathrm{a}$, simili a quelli della faglia a largo di Pozzillo, e compatibili con la deformazione verticale $(1.2 \mathrm{~cm} / \mathrm{a})$ misurata nello stesso settore costiero tramite InSAR (Azzaro et al., 2013).

\section{References:}

Azzaro R. (1999) - Earthquake surface faulting at Mount Etna volcano (Sicily) and implications for active tectonics. In: J. Geodyn. 28:193-213.

Azzaro R. et alii (2013) - Geometry and kinematics of the fault systems controlling the unstable flank of Etna volcano (Sicily). In: J. Volcanol. Geotherm. Res. 251:5-15.

Branca S. et alii (2011) - Geological map of Etna volcano, 1:50,000 scale. Italian Journal of Geosciences 130, 3:265-291.

Chiocci F.L. et alii (2011) -Continental margin large-scale instability controlling the flank sliding of Etna volcano. Earth Planet. Sci. Lett. 305:57-64.

Patanè G., Imposa S. (1995) - Atlante delle isosiste dei terremoti etnei dal 1971 al 1991. CNR-GNGTS. Ist. Geologia e Geofisica Università di Catania, pp 81.

Tanguy J.C. et alii (2012) - New archeomagnetic and 226Ra-230Th dating of recent lavas for the geological map of Etna volcano. In: Ital. J. Geosci. 131:241-257. 


\title{
Risultati preliminari della campagna EUROFLEETS2 LGT - AMORGOS - 56 per lo studio del più grande maremoto del XX secolo nel Mediterraneo orientale
}

\author{
Chiocci F.L. ${ }^{1,2}$, Alonso B. ${ }^{3}$, Casalbore D. ${ }^{1}$, Ceccarelli E.M. ${ }^{1}$, Estrada F. ${ }^{3}$, Gross F. ${ }^{4}$, Georgiou P. ${ }^{5}$, \\ Pampides I. ${ }^{5}$, Mantopoulos P. ${ }^{5}$, Magrini L.C. ${ }^{1}$, Maisto F. ${ }^{1}$, Migeon S. ${ }^{6}$, Morfis I. ${ }^{5}$, Panagiotopoulos I. ${ }^{5}$, \\ Patanè R.A. ${ }^{1}$, Pierdomenico M. ${ }^{2}$, Rousakis G. ${ }^{5}$, Sposato A. ${ }^{2}$, Schulze I. ${ }^{4}$, Sakellariou D. ${ }^{5}$ \& Zavitsanou A. ${ }^{5}$ \\ ${ }^{1}$ Dipartimento di Scienze della Terra, Sapienza Università di Roma. \\ ${ }^{2}$ Istituto Geologia Ambientale e Geoingegneria CNR, Roma. \\ ${ }^{3}$ Consejo Superior de Investigaciones Cientificas, Barcelona. \\ ${ }^{4}$ University of Kiel, Germany. \\ ${ }^{5}$ Hellenic Centre for Marine Research, Athens, Greece. \\ ${ }^{6}$ Geoazur, Nice, France.
}

Corresponding author email: francesco.chiocci@uniroma1.it

Keywords: Egeo, Faglie attive, Maremoti generati da frana.

La crociera LGT AMORGOS-56 (13-23 Giugno 2016, N/O Aegeo) ha avuto come scopo lo studio della sorgente e dei meccanismi di innesco del più grande maremoto del Mediterraneo nel $20^{\circ}$ secolo, che si è verificato dopo il terremoto del 9 luglio 1956 nel Mar Egeo. Il terremoto ha provocato 53 morti e distrutto o gravemente danneggiato circa 2000 edifici. Il maremoto che seguì il terremoto ha colpito le aree circostanti, con i massimi valori di run-up (10-30 m) osservati sulla costa meridionale dell'isola di Amorgos e nelle circostanti isole. Inoltre, la variabilità di questi valori di run-up ha suggerito la presenza di sorgenti locali presumibilmente associate a frane sismo-indotte, la cui identificazione eral'obiettivo finale della campagna. A tal fine, sono stati acquisiti più di $460 \mathrm{~km}$ di profili sismici a riflessione con sorgente air-gun, coperti circa $2.900 \mathrm{~km}^{2}$ con rilievi multibeam, $49 \mathrm{~km}$ di sonar a scansione laterale e sub-bottom Chirp deep tow e raccolte 13 carote a gravità su obiettivi specifici.

L'interpretazione preliminare dei dati ha permesso di identificare sei bacini sedimentari e due alti strutturali (dorsali), tutti con trend SO-NE, la cui caratterizzazione può avere significative implicazioni sull'assetto geodinamico dell'area.

Tutte le aree proposte in letteratura per l'ubicazione della frana(e)tsunamigenica del 1956 sono stati rilevate in dettaglio e si può affermare come per nessuna di loro è stato confermata la presenza di eventi recenti di instabilità gravitativa. Lineamenti morfologici associati ad instabilità gravitativa sono stati individuati altrove, sia a fondo mare e sia nella stratigrafia del bacino. In particolare:

La Frana 1 ha interessato il fianco meridionale (10-15 $5^{\circ}$ in media) della dorsale che delimita il bacino di Astypalea. Si osserva un accumulo di blocchi alla base del fianco esteso su un'area di 700x800 m. I blocchi sono alti circa $10 \mathrm{~m}$ e hanno diametri di 50-70 $\mathrm{m}$.

La Frana 2 ha interessato il ripido fianco sud-orientale dell'isola di Amorgos. La parte più alta si trova a circa $120 \mathrm{~m}$ di profondità, mentre la base e la transizione al bacino si trova a circa $740 \mathrm{~m}$.

La Frana 3 presenta una morfologia complessa ed ha interessato un settore di $10 \mathrm{~km}$ di lunghezza del ripido pendio meridionale dell'isola di Amorgos.

La Frana 4 ha interessato il fianco nord-occidentale dell'isola di Astypalea. Presenta una nicchia semicircolare a circa $370 \mathrm{~m}$ di profondità dell'acqua lunga circa $3 \mathrm{~km}$ di larghezza e $70 \mathrm{~m}$ di altezza. Ai piedi della nicchia è presente un grande ammasso di depositi di frana, apparentemente poco disintegrati. 


\title{
Il panorama delle infrastrutture navali da ricerca italiane dopo il refitting della SPS N/R OGS Explora
}

\author{
Coren F. ${ }^{1}$, Codiglia R. ${ }^{1} \&$ Zgur F. ${ }^{1}$ \\ ${ }^{1}$ Istituto Nazionale di Oceanografia e di Geofisica Sperimentale, Trieste.
}

Corresponding author email: fcoren@inogs.it

Keywords: Infrastrutture, Navi, Ricerca.

Il 6 dicembre 2016 la N/R OGS Explora dopo un refitting durato otto mesi (finanziato con il progetto Bandiera RITMARE) è partita alla volta del Mare di Ross, per svolgere la sua undicesima missione di ricerca in Antartide sotto l'egida del Progetto Nazionale di Ricerche in Antartide.

Il refitting della OGS Explora ha consentito l'ottenimento della classe Special Purpose Ship (SPS) rispondente alla specifica SOLAS 74, e migliori standard di stabilità e galleggiabilità anche in caso di falla. La nave è stata sottoposta ad una profonda manutenzione dell'apparato propulsore, delle coibentazioni e del layout degli alloggi e della sala macchine, che le hanno conferito l'operatività piena per i prossimi tre anni senza significative azioni manutentive.

L'OGS nel 2015/2016 ha inoltre acquisito con fondi propri un sistema sismico multicanale con streamer allo stato solido da $1.5 \mathrm{~km}$ estendibili fino a 8 ed ha effettuato un significativo ammodernamento di tutta la strumentazione, tra cui l'upgrade del sistema multibeam, da 8150 a 7150, che ha consentito di quadruplicare la risoluzione spaziale del sistema.

Il successo di questa operazione non deve però impedire di alzare lo sguardo oltre l'orizzonte attuale; fra sei anni l'OGS Explora, varata nel 1973, raggiungerà i 50 anni di attività. E' opportuno quindi programmare un futuro per la flotta da ricerca italiana, soprattutto nell'ottica della continuazione del Progetto Nazionale di Ricerche in Antartide.

Attualmente la ricerca italiana in mare dispone di tre unità principali, il M/N Della Porta (35.70 m f.t.) il N/R Minerva Uno (46.6 m f.t.) e l'N/R OGS Explora (72.6 m f.t.) e di alcuni navigli minori.

Tra le unità maggiori solamente la OGS Explora è adatta alle operazioni oceaniche ed in Antartide o Artide almeno fino all'estate australe 2017/18, in ottemperanza alle direttive del Polar Code.

Attualmente il supporto logistico della base Mario Zucchelli è deputato alla M/N Italica, che presenta lo stesso problema operativo di non soddisfare le direttive del Polar Code, impedendone de facto il suo utilizzo a partire dalla prossima estate australe. Pertanto con l'entrata in vigore del Polar Code, sia l'Italica (peraltro nave cargo e non da ricerca) e la OGS Explora non potranno operare in acque polari.

Crediamo pertanto sia il caso che la comunità scientifica italiana inizi ad interrogarsi sulla necessità di una nuova nave scientifica di capacità oceanica e polare, polivalente, con spiccate caratteristiche scientifiche e dotata di possibilità di trasporto di carburanti e cargo, tale da consentire, peraltro, il mantenimento logistico a costi ragionevoli della base antartica Mario Zucchelli.

Tale unità, potrebbe essere reperita a costi contenuti, attingendo dal vasto parco di navi usate ed inutilizzate a causa della crisi profonda che ha colpito il settore off-shore, fortemente legato al prezzo del petrolio. Reputiamo inoltre che sia fondamentale, in questa fase congiunturale, tenere in debito conto l'aspetto economico legato sia alla sostenibilità dell'acquisizione ma soprattutto a quella del mantenimento operativo dell'unità. 


\title{
Ash dispersal from Holocene and Late Pleistocene eruptions of Italian volcanoes: the marine record as an archive of moderately explosive volcanic eruptions
}

\author{
Crocitti M. ${ }^{1}$, Sulpizio R. ${ }^{1}$, Insinga D.D. ${ }^{2}$, De Rosa R. ${ }^{3}$, Donato P. ${ }^{3}$, Iorio M. ${ }^{2}$, Zanchetta G. ${ }^{4}$, \\ Barca D. ${ }^{3} \&$ Lubritto C. ${ }^{5}$ \\ ${ }^{1}$ Dipartimento di Scienze della Terra e Geoambientali, Università di Bari Aldo Moro. \\ ${ }^{2}$ Istituto per l'Ambiente Marino Costiero CNR, Napoli. \\ ${ }^{3}$ Dipartimento di Biologia, Ecologia e Scienze della Terra, Università della Calabria, Arcavacata di Rende, Cosenza. \\ ${ }^{4}$ Dipartimento di Scienze della Terra, Università di Pisa. \\ ${ }^{5}$ Dipartimento di Scienze e Tecnologie Ambientali, Biologiche e Farmaceutiche, Seconda Università degli Studi di Napoli.
}

Corresponding author email: roberto.sulpizio@uniba.it

Keywords: Mappe di dispersione, Mediterraneo centrale, Tefrostratigrafia marina

L'analisi stratigrafica con approccio tefrocronologico delle successioni marine del Tirreno, dello Ionio e dell'Adriatico risulta essere particolarmente efficace grazie alla presenza di vulcani italiani attivi durante il Quaternario e ad una dispersione dei prodotti eruttivi verso est e sud-est. Negli ultimi 40 anni, una vasta produzione scientifica dedicata allo studio dei tefra distali ed associata, recentemente, ad analisi di dettaglio dei depositi prossimali, ha consentito di tracciare la dispersione dei prodotti per i maggiori eventi esplosivi. Ad oggi, la dispersione dei prodotti originati da eruzioni esplosive di media intensità, al contrario, è scarsamente conosciuta e per lo più ricostruita attraverso l'analisi di successioni lacustri e marine di zone prossimali. Pochissime informazioni derivano, invece, da archivi marini medio-distali. Questo lavoro presenta i risultati di un'analisi tefrostratigrafica condotta su tre carotaggi a gravità prelevati nel Tirreno meridionale e nel Golfo di Taranto (Mar Ionio) e rappresentativi di ambienti di piattaforma, scarpata e bacino. Le successioni sono rappresentate generalmente da depositi siltosi che registrano gli ultimi 13,000 anni, ed a cui si intercalano in totale 38 tefra/criptotefra. Questi ultimi sono stati caratterizzati in termini di elementi maggiori, minori ed in traccia. I risultati ottenuti hanno consentito di correlare gran parte dei depositi con i prodotti alcalino-potassici del Somma-Vesuvio, dei Campi Flegrei e dell'isola d'Ischia, ed un numero minore di tefra con i prodotti alcalino-sodici e calcalcalini dell'Etna e dell'isola di Lipari, rispettivamente. Per i prodotti correlati con eventi noti a terra sono state create mappe di dispersione e, accanto al riconoscimento di un numero di tefra relativi ad importanti eventi esplosivi che confermano o dettagliano le aree di dispersione già conosciute (e.g. Mercato, Fiumebianco-Gabellotto, Avellino, AP3-4-5, FL, Pompei and Monte Pilato-Rocche Rosse), sono proposti dati originali circa alcune eruzioni di moderata intensità dei vulcani napoletani. Sono state tracciate, infatti, nuove mappe di dispersione per alcuni eventi (Pigna San Nicola, and Averno 2 from Campi Flegrei; VM1, AS2, AD 1723, AD 1730, AD 1779 and AD 1794 from Somma-Vesuvius) ed estesi i limiti di altri (Soccavo 1, Soccavo 4, Averno 1 from Campi Flegrei; Piano Liguori from Ischia Island; AP1-AP2 and AS3 from Somma-Vesuvius). In base ai risultati ottenuti, alcuni degli eventi esplosivi di moderata intensità mostrano aree di dispersione dei prodotti comparabili a quelle già note per altri eventi sub-pliniani con importanti implicazioni, quindi, per la valutazione dell'hazard vulcanico nell'area in esame. Inoltre, il riconoscimento di prodotti vesuviani recentissimi sia nel Tirreno che nel Golfo di Taranto, consente di tracciare nuove isocrone e, quindi, di correlare archivi diversi fornendo così un importante contributo alla ricerca paleoclimatica nel Mediterraneo centrale. 


\title{
First data on coastal monitoring, using both photogrammetry and lidar 3D laser mapping from uav surveys to apply in the coastal management of the strait of Messina (Capo Peloro)
}

\author{
Crupi A. ${ }^{1}$, Lanza S. ${ }^{1} \&$ Randazzo G. ${ }^{2}$ \\ ${ }^{1}$ Dipartimento di Scienze Matematiche e Informatiche, Scienze Fisiche e Scienze della Terra, \\ GeoloGIS srl - Spin off, Università degli studi di Messina. \\ ${ }^{2}$ Dipartimento di Scienze Matematiche e Informatiche, Scienze Fisiche e Scienze della Terra, \\ Università degli studi di Messina.
}

Corresponding author email: antoniocrupi5@hotmail.it

Keywords: Coastal erosion, LiDAR, Photogrammetry, Resilience, Strait of Messina, Unmanned Aerial Vehicles (UAV).

Capo Peloro is the northernmost headland of NE Sicily, facing the Strait of Messina, at the convergence between Tirrenian and Jonian seas. Four beaches, rhythmically licked by the play of the currents, cover the 1 $\mathrm{km}$ from English Tower, on the West side, to the breakwaters of Torre Faro, on the East side.

In this area, during the last 180 years, the changing coastline has been assessed using maps, aerial photographs, urban plans, historical notes, and surveys from 1824 to 2013 (Randazzo et al., 2014).

These tools, based on both spatial and temporal scales, are mostly qualitative and they don't permit to evaluate the volume moved during the seasonal evolution.

In this study the volumetric coastal evolution is started to be monitored using a high-accuracy and highquality photogrammetry frames and a Yelloscan Mapper LiDAR both acquired using two unmanned aerial vehicles (UAV).

The UAV are two otta contra-rotary helicopter drones with a different heavy payload capability.

At the moment we can show the results of the first winter flight (February 2017), performed along the beach of Capo Peloro.

The aim of the study, at this point, is to show the level of accuracy, which can be achieved with photogrammetry and with laser scanner used by drones, flying few tens of meter from the soil.

The volume evolution is calculated comparing these remote information with the topographic profiles, surveyed in the previous years, during the study for the coastal management plan of the Municipality of Messina, interrupted with the election of the new administration.

This first results show the efficacy and applicability of these techniques from UAVs, for supporting authorities in coastal management and designers to plan protections structures and harbours, but also for scientific studies due to its convenient cost/benefit ratio.

\section{References:}

Randazzo G. et alii (2014) - The natural causes of shoreline evolution of Capo Peloro, the northernmost point of Sicily (Italy). In: Green, A.N. and Cooper, J.A.G. (eds.), Proceedings 13th International Coastal Symposium (Durban, South Africa), Journal of Coastal Research, Special Issue No. 70, pp. 199-204, ISSN 0749-0208. 


\title{
Active faulting and continental slope instabilityin the Gulf of Patti (Tyrrhenian side of NE Sicily, Italy):a field, marine and seismological joint analysis
}

\author{
Cultrera F. ${ }^{1}$, Barreca G. ${ }^{1}$, Burrato P. ${ }^{2}$, Ferranti L. ${ }^{3}$, Monaco C. ${ }^{1}$, Passaro S. ${ }^{4}$, Pepe F. ${ }^{5} \&$ Scarfi L. ${ }^{6}$ \\ ${ }^{1}$ Dipartimento di Scienze Biologiche, Geologiche e Ambientali, Università di Catania. \\ ${ }^{2}$ Istituto Nazionale di Geofisica e Vulcanologia, Roma 1. \\ ${ }^{3}$ Dipartimento di Scienze della Terra, delle Risorse e dell'Ambiente, Università di Napoli Federico II. \\ ${ }^{4}$ Istituto per l'Ambiente Marino Costiero CNR, Napoli. \\ ${ }_{5}^{5}$ Dipartimento di Scienze della Terra e del Mare, Università di Palermo. \\ ${ }^{6}$ Istituto Nazionale di Geofisica e Vulcanologia, Osservatorio Etneo, Catania.
}

Corresponding author email: pierfrancesco.burrato@ingv.it

Keywords: Active faulting, Continental slope instability, Earthquakes, North-eastern Sicily, Seismic profiles.

The Gulf of Patti and its onshore sector represent one of the most seismicallyactive regions of the Italian Peninsula. Over the period 1984-2014, about 1800 earthquakeswith small-to-moderate magnitude and a maximum hypocentral depth of $40 \mathrm{~km}$ occurredin this area. Historical catalogues reveal that the same area was affected by several strongearthquakes such as the $\mathrm{Mw}=6.1$ event in April 1978 and the $\mathrm{Mw}=6.2$ one in March1786 which have caused severe damages in the surrounding localities. The main seismotectonicfeature affecting this area is represented by a NNW-SSE trending right-lateralstrike-slip fault system called "AeolianTindari-Letojanni" (ATLFS) which has beeninterpreted as a lithospheric transfer zone extending from the Aeolian Islands to the Ioniancoast of Sicily. Although the large-scale role of the ATLFS is widely accepted, severalissues about its structural architecture (i.e. distribution, attitude and slip of fault segments)and the active deformation pattern are poorly constrained, particularly in the offshore. Anintegrated analysis of field structural geology with marine geophysical and seismologicaldata has allowed to better understand the structural fabric of the ATLFS which, in the studyarea, is expressed by two major NW-SE trending, en-echelon arranged fault segments.Minor NNE-SSW oriented extensional structures mainly occur in the overlap regionbetween major faults, forming a dilatational stepover. Most faults display evidence ofactive deformation and appear to control the main morphobathymetric features. This aspect, together with diffused continental slope instability, must be considered for therevaluation of the seismic and geomorphological hazard of this sector of southernTyrrhenian Sea. 


\title{
Evoluzione di canali torbiditici lungo la scarpata continentale del margine Campano (Mar Tirreno)
}

\author{
Dalla Valle G. ${ }^{1} \&$ Gamberi F. ${ }^{1}$ \\ ${ }^{1}$ Istituto di Scienze Marine CNR, Bologna. \\ Corresponding author email: fabiano.gamberi@bo.ismar.cnr.it
}

Keywords: Bacini di intrascarpata, Canali torbiditici, Canyons Margini continentali.

Il margine continentale della Campania si è sviluppato a partire dal Pliocene in seguito all'apertura del bacino di retro-arco del Marsili, nel Tirreno Meridionale. La scarpata continentale campana è organizzata in una serie di sotto-bacini di intrascarpata confinati da una serie di altri strutturali e blocchi di faglia originatisi durante le fasi di stiramento crostale. I depocentri del margine sono concentrati all'interno dei bacini di intrascarpata, con spessori che decrescono progressivamente procedendo dalle zone di piattaforma (oltre 4 $\mathrm{km})$ alle zone profonde nella scarpata inferiore $(1 \mathrm{~km})$.

Mentre alcuni dei bacini della scarpata superiore sono connessi con gli input sedimentari terrestri attraverso sistemi di canyon-canale ben sviluppati (Ischia, Dhorn e Magnaghi), i bacini di intrascarpata inferiori appaiono completamente disconnessi da sistemi di alimentazione a terra. Tuttavia in alcuni punti del margine, lungo la scarpata, si osserva come le vie di trasporto sedimentario riescono a superare gli ostacoli topografici legati alle strutture tettoniche e a formare una serie di corridoi tortuosi connessi fra loro. Questo setting permette il trasferimento dei sedimenti fino al livello base più profondo del margine, il bacino del Marsili.

Lo studio del margine, condotto attraverso l'integrazione di batimetria ad alto dettaglio con profili sismici ad alta e bassa risoluzione ha permesso di sviluppare un modello concettuale dell'evoluzione dei sistemi di trasporto sedimentario dalle fasi iniziali alle fasi mature.

Il modello prevede la nucleazione di vie di trasporto sedimentario nei settori profondi della scarpata continentale, attraverso lo sviluppo di depressioni create da episodi franosi lungo le scarpate di faglia che bordano i bacini di intrascarpata. Progressivamente, attraverso un processo di franamento retrogressivo, la depressione raggiunge anche la piana del bacino di intrascarpata, fino a mettersi in connessione con il bacino di intrascarpata situato al livello superiore, formando così un network di canyon erosivi connessi fra loro.

Lo stadio intermedio prevede la progressiva connessione dei due sistemi di trasporto situati a due livelli diversi attraverso processi di flow-stripping dei sedimenti dal bacino superiore verso il bacino inferiore, con la formazione di sistemi canalizzati più maturi.

Il risultato finale prevede la formazione di corridoi tortuosi connessi dalla piattaforma continentale alla piana bacinale, dove i sistemi canalizzati sviluppano argini deposizionali e conoidi profonde di intrascarpata.

Lo studio dei sistemi sedimentari attuali del margine campano contribuisce allo sviluppo di strumenti concettuali che possono essere utili ed applicati in contesti antichi di sistemi di mare profondo, caratterizzati da una distribuzione dei sedimenti complicata dal controllo tettono-topografico, nei contesti di margini sia passivi che attivi. 


\title{
Il margine continentale Sud Adriatico: sistemi deposizionali, processi oceanografici e fenomeni di instabilità
}

\author{
Dalla Valle G. ${ }^{1}$, Pellegrini C. ${ }^{1}$, Gamberi F. ${ }^{1}$, Foglini F. ${ }^{1}$, Campiani E. ${ }^{1}$, Rovere M. ${ }^{1}$, \\ Maselli V. ${ }^{2} \&$ Trincardi F. ${ }^{1}$ \\ ${ }^{1}$ Istituto di Scienze Marine CNR, Bologna. \\ ${ }^{2}$ Department of Geology and Petroleum Geology, University of Aberdeen, United Kingdom.
}

Corresponding author email: giacomo.dalla.valle@bo.ismar.cnr.it

Keywords: Cascaditi, Conturiti, Frane sottomarine, Mare Adriatico, Margini continentali.

Indagini geofisiche condotte dall'ISMAR di Bologna lungo il margine occidentale del bacino Sud Adriatico, hanno permesso di ricostruirne l'evoluzione durante il Pliocene-Quaternario (Verdicchio e Trincardi, 2006, Trincardi et al., 2007; Pellegrini et al., 2015). A partire dal Pliocene Inferiore, i depositi della piana bacinale consistono essenzialmente di depositi conturitici (drift) spessi oltre $150 \mathrm{~m}$ (Pellegrini et al., 2015). La geometria del drift riflette l'interazione tra correnti di fondo e morfologia del margine, complicata dalla presenza di alti strutturali come l'Anticlinale di Gondola (Ridente e Trincardi, 2006). Da ca. 800 mila anni fa, la successione stratigrafica è caratterizzata da onde di sedimento a più piccola scala e da corpi conturitici distribuiti anche lungo la scarpata continentale inferiore. Le geometrie degli strati documentano una migrazione delle correnti di fondo verso settori del margine meno profondi. A partire da circa 350 mila anni fa, l'azione delle correnti raggiunge la piattaforma esterna, come testimonia la presenza di onde di sedimento e scours (Verdicchio e Trincardi, 2006). La sequenza tardo-pleistocenica del margine è caratterizzata da diffusa instabilità gravitativa e da frane sottomarine lungo la scarpata (Dalla Valle et al., 2015). I depositi coinvolti appartengono prevalentemente ad unità pleistoceniche consolidate (frane a blocchi) o a depositi conturitici (colate di fango). La frana più estesa (Frana di Gondola, Minisini et al., 2006) originatasi al ciglio della piattaforma copre un'area di $1050 \mathrm{~km}^{2}$. Studi di dettaglio sull'organizzazione interna hanno permesso di riconoscere almeno 3 eventi di franamento: il principale, che ha originato circa il 90\% del volume del corpo di frana, e 2 eventi di minore entità che hanno rimobilizzato parte della frana (Dalla Valle et al., 2015). L'analisi del margine Sud Adriatico ha permesso di mettere in luce la complessa interazione tra topografia del bacino, attività tettonica sin-sedimentaria e regime oceanografico.

\section{References:}

Dalla Valle G. et alii (2015) - The Gondola Slide: A mass transport complex controlled by margin topography (SouthWestern Adriatic Margin, Mediterranean Sea. Marine Geology, 366: 297-313.

Minisini D. et alii (2006) - Evidence of slope instability in the South- Western Adriatic margin. Natural Hazards and Earth Systems Science 6: 1-20.

Pellegrini C. et alii (2015) - Pliocene-Quaternary contourite depositional system along the south-western Adriatic margin: changes in sedimentary stacking pattern and associated bottom currents. Geo-Marine Letters 36: 67-79.

Ridente D., Trincardi F. (2006) - Active foreland deformation evidenced by shallow folds and faults affecting late Quaternary shelf-slope deposits (Adriatic Sea, Italy). Basin Research 18 (2): 171-188.

Trincardi F. et alii (2007) - Seafloor evidence for the interaction between cascading and along-slope bottom water masses. Journal of Geophysical Research 112: 03011.

Verdicchio G., Trincardi F. (2006) - Short-distance variability in slope bed-forms along the Southwestern Adriatic Margin (Central Mediterranean). Marine Geology 234: 271-292. 


\title{
Evolution of coastal systems related to historic Phoenician-Punic centres in the Gulf of Oristano (western Sardinia)
}

\author{
De Falco G. ${ }^{1}$, Conforti A. ${ }^{1}$, Pascucci V. ${ }^{2}$, Sanna I. , Del Vais C. ${ }^{4}$, Gasperini L. ${ }^{5} \&$ Stanghellini G. ${ }^{5}$ \\ ${ }^{1}$ Istituto per l'Ambiente Marino Costiero CNR, Oristano. \\ ${ }^{2}$ Dipartimento di Architettura, Design e Urbanistica, Università degli Studi di Sassari, Alghero. \\ ${ }^{3}$ Soprintendeza Beni Archeologici di Cagliari e Oristano. \\ ${ }^{4}$ Dipartimento di Storia, Beni Culturali e Territorio, Università degli Studi di Cagliari. \\ ${ }^{5}$ Istituto di Scienze Marine CNR, Bologna.
}

Corresponding author email: giovanni.defalco@,cnr.it

Keywords: Barrier, Delta, Holocene, Lagoon, Transgression.

The Gulf of Oristano (western Sardinia) is a wide bay $\left(150 \mathrm{~km}^{2}\right)$ bordered by sandy shores, composed of barrier-lagoon systems, sandy spits and attached barriers, while the backshore is an alluvial plane with lagoons and dune systems. The Tirso River, whose mouth is located in the northeastern sector of the gulf, is the main source of sediments from land. The Gulf represents the western boundary of the Campidano graben, a PlioceneQuaternary structural depression, NW-SE oriented. This basin, a half-graben with the main depocenter located in the Gulf of Oristano, was subjected to an intense exploitation of the coast during Phoenician, Punic and Roman times, with ancient settlements located along the coast and lagoon shores. Integrated archaeological and geological studies were conducted to analyze: (i) the evolution of theTirso river delta and adjacent Santa Giusta lagoon, in relation to the presence of a main Phoenician-Punic center named Othoca, developed along the lagoon shores; and (ii) the evolution of the Mistras barrier lagoon systems, site of a harbour serving the town of Tharros during Phoenician-Punic and Roman times. To this purpose, we analyzed a set of geophysical and stratigraphic data, including high-resolution seismic reflection profiles, multibeam swath bathymetry, 20 boreholes collected along the coast, 2 vibrocores collected in the gulf, as well as further stratigraphic data over more than 70 boreholes collected along the alluvial plane.

The Mistras barrier lagoon system, related to the ancient town of Tharros, developed as transgressive systems during the final stages of the Holocene sea level rise (about 6000 years BP), and became regressive (prograding) from about 2600 years BP. However, the regression of the coastline has been discontinuous, characterized by three distinct phases associated to precise climatic fluctuations. The evolution of Santa Giusta lagoon, which conditioned the history of Othoca, was strictly related to the progradation of the Tirso delta during the last $5 \mathrm{ka}$. Studying changes in time of the lagoon shorelines is thus very important to reconstruct the history of the ancient settlement, and to interpret the nature of underwater archaeological deposits buried in the lagoon dating back between VII and II century BC (2650 and 2150 BP).

The two systems, i.e., lagoon and delta, developed in the same condition of sea level variability. However, they are different mainly in terms of sediment supply and accommodation. The barrier lagoon system is sediment starved and its development was conditioned by human influence, sea level fluctuation and the presence of seagrass meadows; conversely, the deltaic system was a bay-head delta, mainly controlled by the paleovalley morphology and sediments supplied by the river. 


\title{
Sistemi innovativi REA (Rapid Environmental Assessment) per la mappatura dei fondali
}

\author{
Demarte M.
}

Istituto Idrografico della Marina, Genova.

Corresponding author email: maurizio.demarte@marina.difesa.it

Keywords: Autonomous marine vehicle - surface craft, Morfobatimetria, Rapid Environmental Assessment, Unmanned aerial vehicle.

Vengono presentati alcuni aspetti di particolare interesse di una ricerca in corso nell'ambito di un progetto triennale che si rivolge allo sviluppo ed impiego di nuove generazioni di sistemi robotici marini e aerei unmanned, secondo una concezione di valutazione rapida ambientale (Rapid Environmental Assessment REA) innovativa per la mappatura del fondale. Questo studio non è finalizzato solamente al «classico» REA per la gestione di emergenze ma anche all'acquisizione e monitoraggio dell'ambiente secondo un protocollo codificato, riferito a procedure standard e caratterizzato da una sequenza precisa delle azioni con tempi stabiliti di acquisizione, elaborazione e restituzione del dato, in modo da far fronte ad esigenze specifiche che richiedono tempi di intervento ridotti al minimo.Attualmente scienze del mare e tecnologia sono in rapida "evoluzione" e riconosciute secondo una generale implicazione di processi interdisciplinari e loro interazione su diverse scale in spazio e tempo. Il REA è uno strumento che ben si coniuga con un sistema come quello marino-costiero, ambiente per natura dinamico, complesso, vulnerabile, fragile ed estremamente attivo negli evidenti cambiamenti globali. Questo sistema risulta infatti sensibile e vulnerabile non solo alle variazioni dei processi naturali, ma anche alle crescenti pressioni antropiche (occupazione e cambio di uso del suolo, riduzione delle risorse e destabilizzazione degli ecosistemi, espansione del turismo e industrializzazione). Vengono considerate le possibili soluzioni adottabili nell'ambito dei vettori disponibili o sviluppabilinella valutazione rapida del settore marinocostiero, concentrandosi prioritariamente su Autonomous marine vehicle - surface craft (AMV) o su Unmanned aerial vehicle (UAV), associate a sensori innovativi trasportati su mezzi unmanned, sono dunque determinanti per l'efficacia del processo di decision making. In particolare si fa riferimento a dati costieri e dei fondali acquisiti con camere multispettrali sui canali e bande di frequenza prettamente marini da cui viene estratto il dato batimetrico calibrato da sistemi acustici multifascio per una dettagliata analisi morfobatimetrica e della natura del fondale grazie al dato di backscatter acustico. 


\title{
Influenza dei fattori allogenici e autogenici sui processi erosivi caratterizzanti i sistemi torbiditici: un esempio dal sistema torbiditico di capo ferrata (margine orientale Sardo)
}

\author{
Di Blasi F. ${ }^{1} \&$ Gamberi F. ${ }^{2}$ \\ ${ }^{1}$ Dipartimento di Scienze Chimiche, della Vita e della Sostenibilità Ambientale, Università degli studi di Parma. \\ ${ }^{2}$ Istituto di Scienze Marine CNR, Bologna.
}

Corresponding author email: fabiano.gamberi@bo.ismar.cnr.it

Keywords: Sistemi torbiditici

I sistemi torbiditici sono spesso interessati dall'alternanza di fasi erosive e deposizionali che influiscono in maniera importante sulla formazione degli elementi morfologici caratterizzanti (Bouma, 2004; Brothers et al., 2013). I processi erosivi inducono un generale approfondimento del sistema con conseguente sviluppo di morfologie erosive. La persistenza temporale e le dimensioni degli elementi erosivi sono direttamente influenzate dalla variabilità dei fattori che controllano l'evoluzione dei sistemi torbiditici (Peakall \& Sumner, 2015). In questo lavoro è stato investigato il sistema torbiditico moderno di Capo Ferrata, situato nel bacino di intrascarpata del Sarrabus, lungo il margine orientale della Sardegna. Esso rappresenta un esempio di "transient fan" collegato a un livello di base più profondo, situato nel Bacino di Vavilov. Il sistema torbiditico di Capo Ferrata è caratterizzato principalmente da processi erosivi che hanno interessato sia il canyon che il canale, sia gli argini che e la scarpata adiacente. Nella parte più prossimale del sistema, la forte erosione è testimoniata dall'indentazione delle testate del canyon fino a $2.4 \mathrm{~km}$ rispetto al margine della piattaforma continentale attuale. In profondità, inoltre, sono state identificate morfologie minori come "scour" e "plunge pool", coincidenti con cambiamenti di gradiente del fondo del canyon. In particolare, la coalescenza di numerose "scour" ha portato allo sviluppo di una "megascour", identificata come un thalweg embrionale. Ulteriori processi erosivi come la migrazione laterale, e i conseguenti fenomeni di taglio di meandro ed avulsione, hanno interessato le aree di canyon e canale, formando scarpate arcuate e terrazzi lungo gli argini del canale. Inoltre, è stato identificato un tratto di canale abbandonato messo in relazione a uno spostamento laterale del "thalweg" a seguito di un processo di avulsione. La direzione di tale spostamento è stata fortemente influenzata dalla topografia dell'area, concentrandosi nella depressione tra il "thalweg" abbandonato e l'argine meridionale del sistema torbiditico di San Lorenzo, adiacente al sistema di Capo Ferrata.

La prevalenza dei fenomeni erosivi rispetto a quelli deposizionali è stata attribuita all'influenza dei cicli eustatici e alla condizione di disequilibrio del profilo del sistema di Capo Ferrata, dovuta alla presenza di un livello di base più profondo rispetto a quello corrispondente alla base della scarpata continentale su cui si è sviluppato il transient fan.

\section{References:}

Bouma A.H. (2004) - Key controls on the characteristics of turbidite systems. Geological Society, London, Special Publications, 222, 9-22.

Brothers D.S., Ten Brink U.S., Andrews B.D., Chaytor J.D., Twichell C.D. (2013) - Geomorphic process fingerprints in submarine canyons. Marine Geology, 337, 53-66.

Peakall J., Sumner E.J. (2015) - Submarine channel flow processes and deposits: a process-product perspective. Geomorphology, 244, 95-120. 


\title{
Late Holocene vegetation and climate changes recorded by a high resolution marine record from the Gulf of Gaeta (central Italy)
}

\author{
Di Rita F. ${ }^{1}$, Margaritelli G. ${ }^{2,}$, Lirer F. ${ }^{2}$, Bonomo S. ${ }^{2}$, Cascella A. ${ }^{4}$, Insinga D.D. ${ }^{2}$, Petrosino P. ${ }^{5}$, Florindo F. ${ }^{6}$, \\ Lurcock P.C. ${ }^{6}$,Vallefuoco M. ${ }^{2}$, Rettori R. ${ }^{3}$, Ferraro L. ${ }^{2} \&$ Magri D. ${ }^{1}$ \\ ${ }^{1}$ Dipartimento di Biologia Ambientale, Sapienza Università di Roma. \\ ${ }^{2}$ Istituto per l'Ambiente Marino Costiero CNR, Napoli. \\ ${ }^{3}$ Dipartimento di Fisica e Geologia, Università di Perugia. \\ ${ }^{4}$ Istituto Nazionale di Geofisica e Vulcanologia, Pisa. \\ ${ }^{5}$ Dipartimento di Scienze della Terra, dell'Ambiente e delle Risorse, Università degli Studi di Napoli Federico II. \\ ${ }^{6}$ Istituto Nazionale di Geofisica e Vulcanologia, Roma.
}

Corresponding author email: federico.dirita@uniroma1.it

Keywords: Oxygen stable isotope, Planktonic foraminifera, Pollen, Tephrostratigraphy, Tyrrhenian Sea.

We present a high-resolution pollen record (core SW104_C5-C5) collected at a depth of 83 meters in the Gulf of Gaeta (Tyrrhenian Sea), providing information on vegetation and climate changes in the central Mediterranean during the last 5500 years (Margaritelli et al., 2016). Between 5500 and 2500 cal. BP, the Gulf of Gaeta borderland was characterized by an evergreen Quercus-dominated forested landscape mixed with abundant deciduous elements. Between $2500 \mathrm{cal}$. BP and the present day, the coastal territory underwent a general process of forest reduction, partly related to an increase of human pressure on the natural woodlands, and partly due to climate change. In particular, the decrease of summer insolation at the middle latitudes since he mid-Holocene clearly determined a declining trend in arboreal vegetation. Interestingly, the forest vegetation development was punctuated by three major phases of forest decline in correspondence with Bond events 0,2 and 3, suggesting clear teleconnections with the North Atlantic climate oscillation. Consistently, the planktonic foraminifers show unstable climate conditions, with alternations of short-term warm-wet and cold-dry climatic phases. Between 2000 and 1500 cal. BP, a major development of forest cover coupled with changes in the foraminifera and isotope records point to a warm and humid phase, as also reported in many sites of southern Europe. In contrast, a major drop of forest cover between 1100 and 900 cal. BP seems linked to local effects of cold/dry climate oscillations during the Middle Age. During the Little Ice age, in particular in correspondence with the Maünder Minimum, cold winters strongly affected the development of broadleaved tree populations and determined a major sea water cooling. On the whole, the oscillations in the forest canopy recorded in the Gaeta pollen record correspond with considerable precision to supra-regional climate changes, in spite of the effects of human pressure on the vegetation development. We acknowledge the Italian Project of Strategic Interest NEXTDATA (http://www.nextdataproject.it).

References:

Margaritelli G. et alii (2016) - Marine response to climate changes during the last five millennia in the central Mediterranean Sea. In: Global and Planetary Change, 142, 53-72. 


\title{
Caratterizzazione geomorfologica della piattaforma continentale NE della Sicilia attraverso l'interpretazione di dati Multibeam e di profili sismici Chirp
}

\author{
Distefano S. ${ }^{1}$, Gallerani A. ${ }^{2}$, Leidi E. ${ }^{2}$, Mercorella A. ${ }^{2}$, Rovere M. ${ }^{2}$, Di Stefano A. ${ }^{1}$ \& Gamberi F. ${ }^{2}$ \\ ${ }^{1}$ Università degli Studi di Catania. \\ ${ }^{2}$ Istituto di Scienze Marine CNR, Bologna.
}

Corresponding author email: salvodist82@gmail.com

Keywords: Cuneo di highstand, Dati multibeam, Profili sismici chirp, Sistemi di delta.

La piattaforma continentale compresa tra Capo Milazzo e Capo Rasocolmo, nel settore nord-orientale della Sicilia, si estende in direzione SSW-NNE per circa $25 \mathrm{~km}$ con un'ampiezza media di circa $3.5 \mathrm{~km}$. Essa è localizzata lungo un margine tettonicamente attivo, interessato da forti tassi di sollevamento connessi al complesso quadro strutturale che contraddistingue la cintura deformativa che attraversa la Sicilia nordorientale. La piattaforma continentale, rappresentando la porzione sommersa più vicina alla costa, è il luogo in cui agiscono sia i meccanismi di trasporto fluviale, sia i comuni processi oceanografici. La loro interazione definisce, insieme all'attività tettonica e all'oscillazione del livello marino, l'organizzazione e la struttura dei corpi sedimentari che drappeggiano la piattaforma stessa (Gamberi et alii, 2014).

In questo lavoro, viene condotta una caratterizzazione geomorfologica e sismica di dettaglio dei depositi riconosciuti in questa porzione di piattaforma continentale della Sicilia nord-orientale, attraverso l'interpretazione di dati batimetrici Multibeam e profili sismici Chirp. In particolare, in funzione della posizione dei fiumi, del carico di sedimenti trasportato e della morfologia della piattaforma stessa, sono stati riconosciuti sistemi deltizi dall'estensione variabile che costituiscono il più recente cuneo sedimentario di highstand. Nella porzione sud-occidentale e centrale, la presenza di fiumi ben sviluppati comporta un considerevole apporto sedimentario che consente un'ampia estensione dei delta lungo gran parte della piattaforma, con la presenza di canali distributari che permettono la deposizione dei sedimenti nelle porzioni più distali della piattaforma. Al contrario, nella porzione nord-orientale, a causa dello scarso apporto sedimentario da parte di piccoli fiumi, lo sviluppo del cuneo di highstand è limitato soltanto ai settori più interni della piattaforma. Lo sviluppo dei depositi deltizi è anche funzione dello spazio a disposizione per la loro progradazione nella piattaforma continentale. Infatti, nelle porzioni in cui la piattaforma è molto stretta e la testata dei canyons è prossima alla linea di costa, i sistemi deltizi mostrano un'espansione piuttosto ristretta e i fiumi riversano i sedimenti trasportati all'interno dei canyons. Viceversa, dove lo spazio di accomodamento è maggiore i delta occupano un ampio areale. Inoltre, nell'area di studio sono stati riconosciuti dei settori in cui si registra un considerevole sviluppo di corpi deposizionali dalle caratteristiche morfologiche e riflessive riconducibili a quelle di un cuneo trasgressivo, talvolta affiorante sulla stessa piattaforma. Esso si trova in discordanza su una superficie erosionale arealmente continua che costituisce il tetto del basamento di lowstand.

\section{References:}

Gamberi F. et alii (2014) - Geomorphology of the NE Sicily continental shelf controlled by tidal currents, canyon head incision and river-derived sediments. Geomorphology, 217, 106-121. 


\title{
Indagini Magnetometriche ad Alta Risoluzione: Approcci Industriali
}

\author{
Filippone M. ${ }^{3,6}$, Tessarolo C. ${ }^{1,5}$, Ciaccio G. ${ }^{1}$, Corrias N. ${ }^{1}$, Nemola A. ${ }^{1}$, Sorce R. ${ }^{1}$, Cocchi L. ${ }^{2}$, Di Grigoli G. ${ }^{1,4}$ \\ ${ }^{1}$ GBT LTD. \\ 2 Istituto Nazionale di Geofisica e Vulcanologia, Roma 2. \\ ${ }^{3}$ Fugro Osae, GmbH, Germany. \\ ${ }^{4}$ Dipartimento di Scienze della Terra e del Mare, Università degli Studi di Palermo. \\ ${ }^{5}$ Dipartimento di Scienze dell'Ambiente e della Terra, Sezione Scienze e Tecnologie Geologiche, \\ Università degli Studi di Milano Bicocca. \\ ${ }^{6}$ Dipartimento di Ingegneria Navale Elettrica Elettronica e delle Telecomunicazioni, Università degli Studi di Genova. \\ Corresponding author email: g.digrigoli@gbtoffshore.com
}

Keywords: Alta Risoluzione, Analytic Signal, Gradiometro, Magnetometria, Total Field, UXO.

L'esplorazione magnetica si occupa della misura delle variazioni locali del campo magnetico terrestre. Tali anomalie possono essere causate dalla presenza nella crosta di minerali contenenti $\mathrm{Fe}$, o di oggetti ferromagnetici.

Forma, dimensione e ampiezza di un'anomalia indottasono funzione dell'orientamento, geometria, profondità e suscettibilità dell'oggetto stesso, cui si associano intensità e inclinazione del campo magnetico terrestre locale (Mariita, 2007).

Nell'ambito di studi regionali, l'acquisizione del dato magnetometrico viene realizzata per approfondire modelli geologici e tettonici, quali lineamenti morfo-strutturali, evidenze vulcaniche, etc. Nell'ambito dell'esplorazione marina industriale, il rilievo magnetometrico viene utilizzato principalmente per individuare oggetti abbandonati sulla superficie marina o sepolti. In particolare, grande attenzione è data alle indagini tipo UneXploded Ordnance (UXO), quei lavori volti alla bonifica e riqualificazione di aree caratterizzate dalla presenza di oggetti inesplosi.

I magnetometri possono essere suddivisi in due categorie: i vector magnetometers che misurano il campo magnetico lungo una direzione, e i total field magnetometers, che misurano il valore scalare del campo magnetico. Studi ad alta risoluzione richiedono la combinazione di due o più magnetometri total field (configurazione definita "gradiometro"), che consentono di misurare la variazione magnetica lungo i tre assi, discriminando a seconda dell'applicazione o il total field o l'anomalia magnetica.

Per l'elaborazione del dato magnetico, approcci differenti possono essere seguiti in funzione delle specifiche dello studio. Un metodo standard è la creazione di un grid del campo magnetico totale che descrive la distribuzione dei dipoli di anomalia magnetica senza un'accurata informazione spaziale. Un altro approccio è rappresentato dallo studio dell'Analytic Signal, definito come:

$A=\sqrt{ }\left(G^{2} x+G^{2} y+G^{2} z\right)$

dove $G x+G y+G z$ rappresentano le componenti ortogonali dei gradienti del campo magnetico totale.

L'Analytic Signal può essere misurato direttamente attraverso un allineamento di 3 o più sensori sincronizzati, oppure essere stimato (Quasi-Analytic Signal) attraverso l'utilizzo di due sensori sincronizzati (la componente verticale Gz può essere derivata con FFT). In entrambi i casi, il risultato è un'anomalia positiva a campana, dove il valore massimo è stima della posizione XY dell'oggetto. Tale tecnica utilizzata per discriminare le dimensioni, geometrie, georeferenziazione dei target.

La necessità di sviluppare strumenti per rilievi ad alta risoluzione e di applicazioni per la loro interpretazione approfondita si è resa necessaria a seguitodella II Guerra Mondiale, con l'abbandono di numerosi oggetti pericolosi sul fondale marino. Ciò ha richiesto di poter discriminare oggetti anche molto piccoli, valutandone il corretto posizionamento e stimandone l'interro.

\section{References:}

Mariita N.O. (2007) - The Magnetic method.Presented at Short Course II on surface Exploration for Geothermal Resources, Organized by UNU-GTP and KenGen, at Lake Navivash, Kenya.2-17. 


\title{
Evidenze di tettonica trascorrente nell'offshore etneo identificate sulla base di nuovi dati di sismica a riflessione multicanale
}

\author{
Firetto Carlino M. ${ }^{1,2}$, Coltelli M. ${ }^{1}$, Cavallaro D. ${ }^{1}$, Zgur F. ${ }^{2} \&$ Patanè D. ${ }^{1}$ \\ ${ }^{1}$ Istituto Nazionale di Geofisica e Vulcanologia, Osservatorio Etneo, Catania. \\ ${ }^{2}$ Istituto Nazionale di Oceanografia e di Geofisica Sperimentale, Trieste.
}

Corresponding author email: marco.firettocarlino@ingv.it

Keywords: Esperimento TOMO-ETNA, Etna, Mar Ionio, Profili sismici, Push-up.

L'area del Monte Etna (Sicilia orientale, Italia) fornisce uno degli esempi più complessi e studiati di vulcanismo al fronte di una fascia collisionale, sebbene la sua origine ed evoluzione spazio-temporale sono ancora oggetto di dibattito. Il vulcanismo si manifestò, da circa $550 \mathrm{ka}$ a $330 \mathrm{ka}$ anni fa, con eruzioni fissurali lungo una fascia orientata ONO-ESE, compresa tra i paesi di Aci Trezza e Adrano (Branca et al., 2011). I centri eruttivi migrarono poi progressivamente verso NO fino all'attuale stratovulcano Mongibello. Questo studio si focalizza sulle porzioni sommerse del versante sud-orientale etneo.

Alcune centinaia di $\mathrm{km}$ di profili di sismica a riflessione multicanale sono stati ivi acquisiti dall'Istituto Nazionale di Geofisica e Vulcanologia - Osservatorio Etneo nel 2014, nell'ambito dell'esperimento TOMOETNA (Coltelli et al., 2016). L'analisi incrociata tra dati batimetrici ed immagini sismiche evidenzia un alto morfo-strutturale romboedrico, definito come Timpe Plateau (Gross et al., 2016), esteso circa $75 \mathrm{~km} 2$. Esso rappresenta una delle propaggini più settentrionali dell'Avampaese Ibleo, delimitato, anche nelle aree sommerse, da faglie ereditate, orientate circa NNO-SSE e NE-SO (Firetto Carlino et al., 2013).

L'area di studio è inoltre interessata da un elevato grado di deformazione transpressiva, evidenziata da un push-up sviluppato lungo faglie orientate da ONO-ESE a NO-SE, che nell'insieme individuano un settore cuneiforme. Le medesime faglie bordano aree bacinali che mostrano segni di inversione tettonica positiva Plio-Quaternaria, suggerendo una precedente tettonica trastensiva. L'area è infine caratterizzata dalla presenza scatterata di vulcaniti, intercalate ai prodotti Plio-Quaternari o affioranti a fondo mare, e da zone più profonde sismicamente contraddistinte da blanking facies compatibili con intrusioni magmatiche.

Questo assetto strutturale evidenzia il verificarsi di una precedente fase trastensiva, che favorì il vulcanismo a largo del versante sud-orientale etneo. Con l'evolversi della deformazione trascorrente, le aree in trastensione furono interessate da un'inversione tettonica positiva, che ostacolò la risalita dei magmi; la deformazione trastensiva migrò verso NO fino alla posizione degli attuali centri eruttivi etnei.

\section{References:}

Branca S. et alii (2011) - Geological evolution of a complex basaltic stratovolcano: Mount Etna, Italy. In: Ital. J. Geosci., 130 (3): 306-317.

Coltelli M. et alii (2016) - The marine activities performed within the TOMO-ETNA experiment. Annals of Geophysics, 59 (4): S0428.

Firetto Carlino M. et alii (2013) - Seismic facies and seabed morphology in a tectonically controlled continental shelf: The Augusta Bay (offshore eastern Sicily, Ionian Sea). In: Marine Geology, 335: 35-51.

Gross F. et alii (2016) - The limits of seaward spreading and slope instability at the continental margin offshore Mt Etna, imaged by high-resolution 2D seismic data. In: Tectonophysics, 667: 63-76. 


\title{
Earthquake Geology in the Sea of Marmara
}

\author{
Gasperini L. ${ }^{1}$, Polonia A. ${ }^{1}$, Bortoluzzi G. ${ }^{1}$, Ferrante V. ${ }^{1}$ \& Çağatay N. ${ }^{2}$ \\ ${ }^{1}$ Istituto di Scienze Marine CNR, Bologna. \\ ${ }^{2}$ Istanbul Technical University, Turchia.
}

Corresponding author email: luca.gasperini@ismar.cnr.it

Keywords: İzmit earthquake, North-Anatolian Fault, seismo-turbidites, slip-rate, submarine paleoseismology.

Paleoseismology (or Earthquake Geology) is a relatively new discipline that investigates geological records of earthquakes produced directly along the rupture plane and in the vicinity of faults by seismic shaking (i.e., landslides and mass flows). If dateable material is recovered from stratigraphic horizons that experienced successive ruptures, slip-rate and recurrence time of large earthquakes can be reconstructed. Earthquake geology has been widely applied to major seismogenic faults on land, and has become a primary tool for seismic hazard evaluation, but it is still a developing technique offshore (Polonia et al., 2002). We present here some results of collaborative Italian-Turkish marine geology studies in the Sea of Marmara carried out onboard of R/V Urania from 2001 to 2013, in an attempt to apply submarine paleoseismological techniques in this complex geological setting, along the principal deformation zone of the North-Anatolian Fault system.

High-resolution geophysical data were used to define location and geometry of seismogenic faults (Polonia et al., 2004), fault ruptures (Gasperini et al., 2011a) as well as deformation rates at geological time scales integrating several earthquake cycles (Gasperini et al., 2011b). Sediment cores were collected to study the interplay between seismic shaking, margin instability and sedimentation in different tectonically controlled basins (Cagatay et al., 2012), and to provide a chronostratigraphic framework for slip-rate estimate (Polonia et al., 2004).

The earthquake records are represented by turbidite-homogenite mass-flow units, which commonly contain a basal coarse layer, a middle laminated silt layer, and an overlying homogeneous mud layer. Recent highenergy sedimentary layers observed in the Gulf of İmit (eastern Sea of Marmara) can be correlated with historical earthquakes through radionuclide and radiometric dating, providing the average repeat time of ca. 300 years for mass flow events (Cagatay et al, 2012). This method can be applied backwards in time, at least during the entire Holocene, to include a number of seismic cycles, allowing for reliable seismic hazard assessments.

\section{References:}

Cagatay M.N. et alii (2012) - Sedimentary earthquake records in the Izmit Gulf, Sea of Marmara, Turkey. In: Sedimentary Geology, 282, 347-359.

Gasperini L. et alii (2011)a - How far did the surface rupture of the 1999 Izmit earthquake reach in Sea of Marmara? Tectonics, 30, TC6001.

Gasperini L. et alii (2011)b - Geological slip rates along the North Anatolian Fault in the Marmara region. In: Tectonics 30, TC002906.

Polonia A. et alii (2002) - Exploring Submarine Earthquake Geology in the Marmara Sea. In: EOS, Transactions, America Geoph. Union, 83, 21.

Polonia A. et alii (2004) - Holocene Slip rate of the North Anatolian Fault beneath the Sea of Marmara. In: Earth and Planetary Science Letters, 427, 411-426. 


\title{
Contributo per lo studio di aree estreme: un esempio di modelling nelle regioni polari
}

\author{
Giustiniani M. ${ }^{1}$ \& Tinivella U. ${ }^{1}$ \\ ${ }^{1}$ Istituto Nazionale di Oceanografia e di Geofisica Sperimentale, Trieste.
}

Corresponding author email: mgiustiniani@inogs.it

Keywords: Gas idrati, Modelling, Piattaforma artica.

I cambiamenti climatici, evidenziati da molti studi, stanno causando un aumento delle temperature, che potrebbero portare alla dissociazione dei gas idrati con conseguente rilascio del gas accumulato nella loro struttura, specialmente nell'artico. Le regioni polari sono aree estreme in cui è difficile acquisire dati. Per questo motivo, proponiamo di utilizzare il modelling per colmare l'inevitabile lacuna di dati.

Nella piattaforma artica, non sussistono le condizioni per la stabilità degli idrati a causa della bassa pressione (acque basse). Molti autori, però, hanno evidenziato una relazione tra permafrost sottomarino (PSM) e stabilità dei gas idrati (SGI) (Romanovskii et al., 2005). Sulla base di queste considerazioni, quindi, è necessario capire i processi associati con il rilascio di metano e quindi poter valutare i potenziali rischi.

In questo lavoro, si analizza la relazione tra PSM e SGI, in acque minori di $200 \mathrm{~m}$ (i.e., Giustiniani et al., 2013), dove l'idrato non è stabile tramite il modelling.

Per valutare la relazione tra PMS e la SGI, è stata calcolata la base teorica di SGI (Sloan 1998) considerando l'area dove è ipotizzata la presenza di PSM (Collett et al., 2011). I dati di input sono: profondità del mare, temperatura del fondo mare, gradiente geotermico (GG), spessore del PSM e composizione del gas (supposto metano). La batimetria è convertita in pressione utilizzando una densità media dell'acqua pari a $1046 \mathrm{~kg} / \mathrm{m} 3$. Il GG è stato supposto uguale ai seguenti valori al di sotto del PMS: $0.025,0.050,0.075$, e $0.100^{\circ} \mathrm{C} / \mathrm{m}$. Sulla base dei risultati ottenuti da diversi autori (i.e., Romanovskii et al., 2005) sono stati considerati 5 diversi spessori di PSM: 100, 150, 200, 250 e $300 \mathrm{~m}$.

È chiaro che la presenza del PSM può causare la SGI in acqua basse (minori di $200 \mathrm{~m}$ ), dove in condizioni normali la stabilità non è verificata. Si può concludere quindi che al di sotto del PSM, formatosi nel passato e ancora presente (i.e., Romanovskii et al., 2005), potrebbe essere presente un importante spessore di gas idrato e gas libero.

In conclusione molti sforzi dovrebbero essere fatti per aumentare le conoscenze riguardo la relazione tra PSM e gas idrati al fine di prevedere i possibili effetti sui cambiamenti climatici, in particolare nelle aree di mare basso dove questi cambiamenti sono amplificati.

\section{References:}

Collett T.S., Lee M.W. et alii (2011) - Permafrost-associated natural gas hydrate occurrences on the Alaska North Slope. In: Mar Pet Geol, 28:279-294

Giustiniani M., Tinivella U. et alii (2013) - Arctic ocean gas hydrate stability in a changing climate. In: J Geol Res. doi:10.1155/2013/783969.

Romanovskii N.N., Hubberten H-W. et alii (2005) - Offshore permafrost and gas hydrate stability zone on the shelf of East Siberian Seas. In: Geophys Mar Lett, 25:167-182. doi:10.1007/s00367-004-0198-6.

Sloan E.D. (1998) - Clathrate hydrates of natural gases. 2nd edn. Marcel Dekker, New York. 


\title{
Il sistema di monitoraggio marino dei Campi Flegrei (MEDUSA): nuovi dati e nuove prospettive per la geodesia marina
}

\author{
Iannaccone G. ${ }^{1}$, De Martino P. ${ }^{1}$, Guardato S. ${ }^{1}$, Donnarumma G.P. ${ }^{1}$, Martino C. ${ }^{1}$, Chierici F. ${ }^{2,3}$ \& Beranzoli L. ${ }^{1}$ \\ ${ }^{1}$ Istituto Nazionale di Geofisica e Vulcanologia, Napoli. \\ 2 Istituto di Radioastronomia, Istituto Nazionale di Astrofisica, Bologna. \\ ${ }^{3}$ Istituto di Scienze Marine CNR, Bologna.
}

Corresponding author email: giovanni.iannaccone@ingv.it

Keywords: Monitoraggio

MEDUSA (Multiparametric Elastic-beacon Devices and Underwater Sensors Acquisition system) è un sofisticato sistema per il monitoraggio in mare dell'attività vulcanica dei Campi Flegrei realizzato come completamento delle reti di strumentazione geofisica esistenti sulla terraferma e gestite dall'INGV-Osservatorio Vesuviano. Tale sistema è costituito da quattro boe attrezzate con strumentazione geofisica e ambientale e trasmissione dei dati in continuo e in tempo reale al Centro di Monitoraggio INGV di Napoli.

Gli obiettivi del sistema sono:

- migliorare la definizione del campo deformativo dell'area tramite misure in continuo dei movimenti del suolo sul fondale marino (componente verticale e orizzontali)

- migliorare la localizzazione dei terremoti dell'area

- abbassare la soglia di detezione di eventi sismici

- sperimentare metodologie innovative per la misura di movimenti del suolo sul fondale marino

- acquisire competenze nello sviluppo e gestione di strumentazione marina

Il sistema MEDUSA è costituito da quattro boe, di tipo meda elastica o a palo, posizionate su fondali variabili da 40 a $100 \mathrm{~m}$ di profondità ad una distanza compresa tra 1,1 e 2,4 km dalla linea di costa.

A ciascuna boa è collegato, tramite un cavo (per trasmissione dati e alimentazione), un modulo sottomarino, adagiato sul fondo a pochi metri di distanza dalla zavorra della boa, ed equipaggiato con strumentazione scientifica e di controllo. In particolare, ciascun modulo ospita un sensore sismico, idrofono, accelerometro, sensore di pressione di precisione.

Inoltre sulla parte emersa di ciascuna boa è presente un ricevitore GPS geodetico dello stesso modello della rete permanente che, grazie alla particolarità costruttiva delle boe, consente la misura dei movimenti del suolo a fondo mare, sia per la componente verticale che per le orizzontali.

Anche il sensore di pressione, attraverso la misura delle variazioni di pressione idrostatica connesse a movimenti verticali del fondo marino, costituisce un innovativo e ancora in fase sperimentale sistema per lo studio del bradisismo nel Golfo di Pozzuoli.

Il sistema è pienamente operativo da meno di un anno producendo con continuità dati originali di movimento del suolo a fondo mare mai osservati finora, fornendo così un primo sguardo dell'andamento del campo deformativo della parte sommersa dei Campi Flegrei.

\section{References:}

Chierici F. et alii (2016) - A new method to assess long-term sea-bottom vertical displacement in shallow water using a bottom pressure sensor: application to Campi Flegrei, Southern Italy, Journal Geophysical Research.

De Martino P. et alii (2014) - A first GPS measurement of vertical seafloor displacement in the Campi Flegrei Caldera (Italy). Journal of Volcanology and Geothermal Research.

Iannaccone G. et alii (2010) - Long-term seafloor experiment with the CUMAS module: performance, noise analysis of geophysical signals, and suggestions about the design of a permanent network,Seismological Research Letters. 


\title{
Il sistema idrotermale al largo dell'Isola di Zannone (Mar Tirreno centrale): nuovi risultati e prospettive.
}

\author{
Ingrassia M. ${ }^{1}$, Martorelli E. ${ }^{1}$, Italiano F. ${ }^{2}$, Macelloni L. ${ }^{5}$, Bosman A. ${ }^{1}$, Conte A.M. ${ }^{4}$, Di Bella L. ${ }^{3}$, Frezza V. ${ }^{3}$, \\ Sposato A. ${ }^{1} \&$ Chiocci F.L. ${ }^{1,3}$ \\ ${ }^{1}$ Istituto Geologia Ambientale e Geoingegneria CNR, Roma. \\ ${ }^{2}$ Istituto Nazionale di Geofisica e Vulcanologia, Palermo. \\ ${ }^{3}$ Dipartimento di Scienze della Terra, Sapienza Università di Roma. \\ ${ }^{4}$ Istituto di Geoscienze e Georisorse CNR, Roma. \\ ${ }^{5}$ National University of Sciences and Technology, University of Mississippi, USA.
}

Corresponding author email: michela.ingrassia@uniroma1.it

Keywords: Comunità bentoniche, Fluidi, mattes batteriche, Pockmark, Sistema idrotermale

Il sistema idrotermale di Zannone (Isole Pontine occidentali, Mar Tirreno) è stato recentemente investigato nell'ambito di campagne di ricerca finanziate dal CNR, utilizzando un approccio di studio multidisciplinare (analisi geofisiche, geochimiche, micropalontologiche, mineralogico-petrografiche.).

Il sistema idrotermale individuato in prossimità dell'Isola di Zannone si caratterizza per la presenza di depressioni del fondo del mare di grandi dimensioni (lunghezza $>250 \mathrm{~m}$ ), ubicate a profondità comprese tra 100 e $150 \mathrm{~m}$. Alcune di esse sono caratterizzate da numerose strutture associate ad emissioni di fluidi sottomarine (pockmark, strutture autigene, mattes batteriche, camini idrotermali, emissioni di fluidi). La depressione di maggiori dimensioni (Zannone Giant Pockmark) è caratterizzata da una complessa architettura e da lineamenti morfologici associati ad un intenso campo idrotermale a sua volta composto da cinque sub-crateri originati da eventi di collasso (Ingrassia et al., 2015).

Tali emissioni risultano caratterizzate da gas arricchiti in $\mathrm{CO} 2$ e $\mathrm{CH} 4$, con rapporti isotopici $(3 \mathrm{He} / 4 \mathrm{He})$ indicativi della loro derivazione da una sorgente magmatica profonda (Martorelli et al., 2016).

Video ad alta risoluzione hanno evidenziato la presenza di altre depressioni caratterizzate da emissioni attive e strutture associate ad attività idrotermale. Campionamenti diretti dei fondali hanno permesso di caratterizzare specifiche associazioni a foraminiferi bentonici agglutinanti (Spiculosiphon oceana, Jaculella acuta e Deuterammina rotaliformis) del tutto peculiari per l'area mediterranea (Di Bella et al., 2016). Tali associazioni, insieme alla mancanza di specie a guscio calcareo, sembrano testimoniare la presenza di intensi fenomeni di dissoluzione. Questo primo studio ha portato alla pianificazione di una campagna di ricerca (ZHF) che si terrà a Febbraio 2017, per l'installazione di un modulo multiparametrico per il monitoraggio ambientale volto a determinare le variazioni di intensità e genesi dei fluidi. I risultati delle analisi, permetteranno di approfondire le conoscenze dei sistemi idrotermali a basse profondità ancora poco conosciuti e di comprendere le interazioni esistenti tra i processi chimico-fisici, biologici e geologici, nonchè il loro impatto sull'ambiente marino circostante (es. processi di acidificazione).

\section{References:}

Di Bella L. et alii (2016) - The response of benthic meiofauna to hydrothermal emissions in the Pontine Archipelago, Tyrrhenian Sea (central Mediterranean Basin). J Marine Syst, 164, 53-66.

Ingrassia M. et alii ( 2015) - The Zannone Giant Pockmark: first evidence of a giant complex seeping structure in shallowwater, central Mediterranean Sea, Italy Mar Geol, 363, 28-51.

Martorelli et alii (2016) - Evidence of a shallow water submarine hydrothermal field off Zannone Island from morphological and geochemical characterization: implications for Tyrrhenian Sea Quaternary volcanism: A new hydrothermal field off Zannone I. J Geophys Res-Sol Ea. 


\title{
Classificazione automatica con RSOBIA (Remotely Sensing Object Based Image Analysis) per la realizzazione della mappa dei fondali dell'Isola di Linosa
}

\author{
Innangi S. ${ }^{1}$, Tonielli R. ${ }^{1}$, Di Martino G. ${ }^{1}$ \& Giardina F. ${ }^{2}$ \\ ${ }^{1}$ Istituto per l'ambiente Marino Costiero CNR, Napoli. \\ ${ }^{2}$ Area Marina Protetta Isole Pelagie, Lampedusa.
}

Corresponding author email: sara.innangi@cnr.it

Keywords: Classificazione automatica delle immagini, Backscatter, Mosaico acustico, Multibeam, ROV.

In questo lavoro viene presentata l'applicazione del toolbox per ArcMap 10.x, RSOBIA (Remote Sensing Object Based Image Analysis), per la realizzazione della carta dei fondali dell'isola di Linosa. Linosa è un'isola vulcanica appartenente all'arcipelago delle Pelagie, ha un'estensione di 5,4 Km2 ed è situata al centro del Mar Mediterraneo, tra la Sicilia e la Tunisia. La mappatura dei suoi fondali è stata effettuata a seguito della convenzione "Realizzazione di Attività di ricerca e Monitoraggio nell'Area Marina Protetta (AMP) Isole Pelagie" stipulata tra l'IAMC ed il Comune di Lampedusa e Linosa, Ente Gestore dell'AMP “Isole Pelagie". Ė nata per lo svolgimento degli studi morfobatimetrici nell'area marino costiera dell'isola di Linosa, finalizzati in particolare alla mappatura dei fondali per la definizione delle biocenosi prioritarie (Posidonia oceanica e coralligeno). Sono state svolte, quindi, acquisizioni batimetriche e di backscatter con ecoscandaglio multifascio Reson Seabat 7125 e transetti con strumentazione ROV (Remotely Operated underwater Vehicle) per la caratterizzazione dei fondali e il riconoscimento delle facies acustiche (i.e. De Falco et al., 2010; Innangi et al., 2015; Tonielli et al., 2016). Tutti i dati raccolti sono stati integrati con RSOBIA, un toolbox sviluppato dal gruppo di ricerca di "Habitat Mapping and Characterization" del NOC (National Oceanography Centre) di Southampton (Le Bas, 2015). Identificando le aree con proprietà statistiche simili, RSOBIA fornisce un metodo ripetibile ed oggettivo per produrre mappe tematiche del fondo sulla base di una serie di informazioni ottenute dalle immagini raster (tra cui la batimetria, il backscatter e le variabili ambientali derivanti, come ad esempio la pendenza e la rugosità). A partire dal mosaico acustico, insieme alle informazioni batimetriche, su cui è calcolata la pendenza e la rugosità del fondo, il software suddivide l'immagine in un determinato numero di classi il cui valore (Majority) rappresenta la maggior classe comune a tutti i pixel di un poligono. Il passaggio successivo consiste nell'associare alla classe le osservazioni sedimentologiche ottenute dalle verità a mare, campionamenti e filmati ROV (groundtruth samples).

\section{References:}

De Falco G. et alii (2010) - Relationships between multibeam backscatter, sediment grain size and Posidonia oceanica seagrass distribution. Continental Shelf Research, 30, 18: 1941-1950.

Innangi S. et alii (2015) - Reson SeaBat 8125 backscatter data as a tool for seabed characterization (Central Mediterranean, Southern Italy): Results from different processing approaches. Applied Acoustics, 87: 109-122.

Tonielli R. et alii (2016) - Distribution of Posidonia oceanica (L.) Delile meadows around Lampedusa Island (Strait of Sicily, Italy). Journal of Maps, 5647.

Le Bas T. (2015) - Remote Sensing Object Based Image Analysis - RSOBIA. National Oceanography Centre, Version $7.183,2-16$ 


\title{
L'Istituto Idrografico della Marina e lo SCUFN (Sub-Committee on Undersea Feature Names)
}

\author{
Ivaldi R. \& Sinapi L. \\ Istituto Idrografico della Marina, Genova.
}

Corresponding author email: roberta_ivaldi@marina.difesa.it

Keywords: Bathymetric chart

Il SCUFN (Sub-Commitee on Undersea Feature Names) è una sotto commissione GEBCO (General Bathymetric Chart of the Oceans) composta da 12 membri in rappresentanza dell'IOC (International Oceanographic Commission) e dell'IHO (International Hydrographic Organization) e ha come principale obiettivo quello di selezionare i nomi e definire l'estensione dei caratteri dei fondali marini che vengono riportati nel GEBCO International Gazetteer e supplementi. Questo processo è l'ultima fase di un processo che inizia presso le autorità nazionali preposte per l'aggiornamento dei nomi dei caratteri dei fondali e la sottomissione allo SCUFN di nuovi nomi dei caratteri non presenti nel dizionario geografico (GEBCO Undersea Feature Names Gazetteer) secondo quanto previsto dallo standard internazionale (IHO B6 - Standardization of Undersea Feature Names - Guidelines, Proposal Form Terminology). Lo SCUFN supporta questa azione fornendo elementi a tutti i soggetti e in particolare alle autorità competenti sulla scelta dei caratteri sottomarini in acque internazionali e, su richiesta, in acque soggette alla giurisdizione nazionale. La preparazione e il mantenimento di linee guida internazionali condivise per la standardizzazione dei nomi dei caratteri dei fondali marini e il loro uso sono sicuramente la chiave fondamentale in cui lo SCUFN esprime il ruolo del proprio operato. Ampia diffusione e incoraggiamento dell'uso di questi nomi che sono riportati sui prodotti GEBCO, documenti per la sicurezza della navigazione, carte e pubblicazioni scientifiche ne sono espressione concreta. La recente grande crescita tecnologico-scientifica dell'esplorazione dei fondali ad elevata risoluzione risulta essere un grande catalizzatore nell'implementazione del GEBCO Undersea Feature Names Gazetteer. In questo contesto l'Istituto Idrografico della Marina rappresenta per la comunità nazionale il focal point a supporto dello SCUFN nella crescita del geodatabase globale secondo gli obiettivi sopracitati, e soprattutto per le esigenze sempre più contingenti dei nuovi standard cartografici internazionali sviluppati con l'IHO S100 - IHO Universal Hydrographic Data Model. 


\title{
Scenari sismico e di tsunami del terremoto del 1905 (Calabria Occ., Tirreno SE) come strumento di analisi del rischio
}

\author{
Loreto M.F. ${ }^{1}$, Pagnoni G. ${ }^{2}$, Pettenati F. ${ }^{3}$, Armigliato A. ${ }^{2}$, Tinti S. ${ }^{2}$, Sandron D. ${ }^{3}$, Brutto F. ${ }^{4}$, Muto F. ${ }^{4}$, \\ Facchin L. ${ }^{3} \&$ Zgur F. ${ }^{3}$ \\ ${ }^{1}$ Istituto di Scienze Marine CNR, Bologna. \\ ${ }^{2}$ Dipartimento di Fisica e Astronomia, Università di Bologna. \\ ${ }^{3}$ Istituto di Oceanografia e Geofisica Sperimentale, Trieste. \\ ${ }^{4}$ Dipartimento di Biologia, Ecologia e Scienze della Terra, Università della Calabria, Arcavata di Rende, Cosenza.
}

Corresponding author email: filomena.loreto@bo.ismar.cnr.it

Keywords: Impatto ambientale, Scenari KF, Scenari tsunami, Tettonica attiva, Rischio sismico.

L'Italia è una delle regioni sismicamente più attive nell'area del Mediterraneo centrale e uno dei paesi con il catalogo della sismicità storica più dettagliato al mondo. Durante gli ultimi decenni la comunità scientifica ha investito grandi risorse nella valutazione del rischio sismico e da maremoto, e allo stesso tempo ha riconosciuto il grande valore dei dati storici quando utilizzati per vincolare i modelli di analisi del rischio. Il terremoto del 1905, che colpì le coste della Calabria Occidentale, è un interessante caso di studio che permette l'applicazione di modelli vincolati dalle informazioni storiche.

In questo poster viene presentata un'analisi deterministica basata su scenari ipotizzando che un terremoto come quello del 1905 si verifichi sulla Faglia di Sant'Eufemia, che è una faglia normale attiva. La geometria della faglia sorgente è stata determinata utilizzando dati geologici e morfologici a terra e dati geofisici acquisiti nel Golfo di Sant'Eufemia a bordo della N/R OGS-Explora nel 2010. Per l'evento del 1905, si è stimato che la rottura si sia propagata per $40 \mathrm{~km}$ e che lo slip cosismico sia stato di $2.3 \mathrm{~m}$. Utilizzando le formule di Wells \& Coppersmith (1994), ne risulta una Mw di 6.9. Le simulazioni di tsunami, fatte con il codice numerico UBO-TSUFD, e la distribuzione delle intensità MCS, calcolata mediante il metodo che utilizza la funzione cinematica KF, sono state confrontate con i dati storici e riportate in mappa per valutare il possibile impatto sul sistema economico-ambientale circostante. Tali informazioni integrate con le mappe degli effetti ambientali hanno permesso di delimitare le aree che risultano maggiormente esposte al rischio. Dal momento che alcune di queste hanno un elevato interesse economico/turistico e popolazione in continua crescita, ne segue che tali aree necessitano di piani di sviluppo adeguati per migliorarvi la mitigazione e prevenzione del rischio.

\section{References:}

Rovida A. et alii (2011) - CPTI11, la versione 2011 del Catalogo Parametrico dei Terremoti Italiani. In: http://emidius. mi.ingv.it/CPTI, Milano, Bologna.

Wells D., Coppersmith K. (1994) - New empirical relationship among magnitude, rupture length, rupture width, rupture area and surface displacement. In: Bull. Seism. Soc. Am., 84: 974-1002. 


\title{
Three-dimensional modelling of the Calabrian Subduction Interface
}

\author{
Maesano F.E. ${ }^{1}$, Tiberti M.M. ${ }^{1}$ \& Basili R. ${ }^{1}$ \\ ${ }^{1}$ Istituto Nazionale di Geofisica e Vulcanologia, Roma.
}

Corresponding author email: francesco.maesano@ingv.it

Keywords: 3D modelling, Calabrian Arc, Seismic interpretation, Subduction interface.

The Calabrian Arc is a one-of-a-kind subduction zone. It features one of the shortest subduction segment $(<150 \mathrm{~km})$, one of the thickest accretionary wedge, and the oldest subducted (280 Myr) oceanic crust of the World. Despite a convergence rate of $1-5 \mathrm{~mm} / \mathrm{yr}$ and significant in-slab seismicity below $40 \mathrm{~km}$ depth, its shallow interface shows no sign of seismic activity. Nonetheless, it has occasionally been blamed to have generated some past large earthquakes and tsunamis. For all these reasons, the Calabrian Arc is a cornerstone in the Mediterranean plate-tectonics puzzle and the understanding of its geometry and behavior may strongly contribute to estimating the seismic and tsunami hazard in the region.

This work presents a 3D reconstruction of the shallow portion $(<20 \mathrm{Km})$ of the Calabrian Subduction interface based on the interpretation of ca. 60 seismic reflection profiles, and its tentative connection with the deeper slab $(>40 \mathrm{~km})$, constrained by the seismicity distribution. The seismic profiles were mostly provided in the collaborative framework between Spectrum and INGV (CA-60).

The three-dimensional reconstruction highlights the detailed geometry and roughness of the subduction interface. Of particular interest is also the western lateral boundary of the subduction interface where a STEPlike fault system has been characterized in detail.

The results of this work have been already presented at the AGU Fall Meeting (San Francisco, December 2016). 


\title{
Architettura stratigrafico-sequenziale delle sequenze deposizionali quaternarie lungo il margine tirrenico da La Spezia all'Argentario
}

\author{
Maisto F. ${ }^{1} \&$ Chiocci F.L. ${ }^{1,2}$ \\ ${ }^{1}$ Dipartimento di Scienze della Terra, Sapienza Università di Roma. \\ ${ }^{2}$ Istituto di Geologia Ambientale e Geoingegneria CNR, Roma.
}

Corresponding author email: federica.maisto@uniroma1.it

Keywords: Mar Tirreno, Piattaforma continentale, Quaternario, Stratigrafia sequenziale, Variazioni del livello marino.

Un ampio dataset di profili sismici ad alta e altissima risoluzione ha permesso di ricostruire le caratteristiche stratigrafico-deposizionali di un esteso settore di margine tirrenico compreso tra La Spezia e l'Argentario (Mar Tirreno Settentrionale).

L'assetto stratigrafico dell'area è caratterizzato da sequenze deposizionali di $\mathrm{IV}^{\circ}$ ordine che registrano le principali variazioni glacio-eustatiche quaternarie. Le sequenze deposizionali, caratterizzate principalmente da geometrie clinoformi, sono indicative di fasi progradazionali della piattaforma continentale che avvengono essenzialmente durante la prolungata fase di caduta del livello del mare ( $\sim 100 \mathrm{~m}$ in $\sim 100.000$ anni). Pertanto, i depositi quaternari sono costituiti nella quasi totalità, da depositi progradanti della fase di caduta (FSST) e localmente, da depositi di basso stazionamento (LST): entrambi sono troncati alla loro sommità da una discordanza erosiva regionale, formatasi durante l'ultimo massimo glaciale (MIS 2) e rielaborato durante il successivo innalzamento del livello del mare.

Le principali sequenze deposizionali riconosciute sismostratigraficamente sono state interpretate in relazione ai principali fattori di controllo (regionali e locali) dell'architettura deposizionale. Confrontando i diversi settori strutturalmente e paleogeograficamente differenti lungo il margine studiato (suddivisibili in base alla presenza di alti strutturali e isole) risulta evidente come uno dei principali fattori di controllo sia quello eustatico, la cui asimmetria è testimoniata dalla maggiore preservazione dei depositi regressivi. La distribuzione degli spessori delle sequenze deposizionali (sia laterale che verticale) risulta influenzata dalla presenza di alti strutturali (Secche della Meloria, Secche di Vada, Formiche di Grosseto), in corrispondenza dei quali diminuisce lo spazio di accomodamento. In dettaglio, i massimi spessori vengono conservati nel settore compreso tra La Spezia e Livorno dove aumentano gradualmente da SO verso NE, in accordo con l'aumento di subsidenza verso il bacino di Viareggio.

Importanti considerazioni di questo tipo, riconoscere e differenziare le aree maggiormente subsidenti da quelle in sollevamento, sono state effettuate dall' analisi delle profondità a cui si rileva il passaggio unconformitycorrelative conformity, considerato marker della paleo-linea di riva durante il basso stazionamento dei minimi eustatici quaternari e la cui preservazione è legata alla subsidenza. Calcolando le differenze rispetto alla posizione attesa per le stesse sulla base delle curve eustatiche ricavate dagli stadi isotopici, è stato possibile valutare il ruolo e quantificare la subsidenza. 


\title{
Sea surface temperature reconstruction over the last five millennia in the Sicily Channel (central Mediterranean): $\mathrm{Mg} / \mathrm{Ca}$ ratio from planktonic foraminifer Globigerinoides ruber
}

\author{
Margaritelli G. ${ }^{1,2}$, Cacho I. ${ }^{3}$, Català A. ${ }^{3}$, Rettori R. ${ }^{2}$, Bonomo S. ${ }^{1}$, Cascella A. ${ }^{4}$ \& Lirer F. ${ }^{1}$ \\ ${ }^{1}$ Istituto per l'Ambiente Marino Costiero CNR, Napoli. \\ ${ }^{2}$ Dipartimento di Fisica e Geologia, Università di Perugia. \\ ${ }^{3}$ Departament de Dinàmica de la Terra i de l'Oceà, Universitat de Barcelona, Spain. \\ ${ }^{4}$ Istituto Nazionale di Geofisica e Vulcanologia, Pisa.
}

Corresponding author email: fabrizio.lirer@enr.it

Keywords: SST, cambiamenti climatici, Canale di Sicilia, $\mathrm{Mg} / \mathrm{Ca}$ G. ruber, ultimi millenni

Sea Surface Temperatures (SST) reconstruction over the last five millennia has been investigated on marine core SW104-ND11 collected in the western Sicily Channel, at a water depth of $475 \mathrm{~m}$. We compared the estimated SST Mg/Ca anomaly ratios on the planktonic foraminifer Globigerinoides ruber alba variety (core SW104-ND11) with SST anomaly reconstructed by $\mathrm{Mg} / \mathrm{Ca}$ from Globigerina bulloides of composite core HER-MC-MR3 of Menorca basin (Cisneros et al., 2016) to propose a past climate reconstruction for the central and western Mediterranean. SST $\mathrm{Mg} / \mathrm{Ca}$ G. ruber results indicate a long-term warming trend from $3400 \mathrm{BCE}$ to ca. $330 \mathrm{CE}$ in the Sicily Channel, interrupted by abrupt short-time anomaly excursions. The comparison with SST Mg/CaG. bulloides data from Menorca Basin and with SST Uk37 reconstruction from Aegean Sea (Kotthoff et al., 2008), suggests a synchronous response at Mediterranean scale between from 100 $\mathrm{BCE}$ to $500 \mathrm{CE}$, documenting the occurrence of a distinct warm phase (Roman Period) of ca. $2.3^{\circ} \mathrm{C}$ positive anomaly. At ca. $600 \mathrm{CE}$ a further cooling phase is recorded, which age corresponds to the Late Antique Little Ice Age (LALIA); after this event the $\mathrm{SST} \mathrm{Mg} / \mathrm{CaG}$. ruber reconstruction documents the onset, at ca. $1180 \mathrm{CE}$, of the well-known Medieval Warm Period. The cooling associated to the Little Ice Age event occurs between $1320 \mathrm{CE}$ and ca. $1850 \mathrm{CE}$ with an anomaly of ca. $2^{\circ} \mathrm{C}$ vs negative values.

We acknowledge financial support from the Italian Project of Strategic Interest NEXTDATA (http://www. nextdataproject.it/) "A national system for recovery, storage, accessibility and dissemination of environmental and climatic data from mountain and marine areas"

\section{References:}

Cisneros M., Cacho I. et alii (2016) - Sea surface temperature variability in the central-western Mediterranean Sea during the last 2700 years: a multi-proxy and multi-record approach. Clim. Past, 12, 849-869.

Kotthoff U., Pross J. et alii (2008) - Climate dynamics in the borderlands of the Aegean Sea during formation of Sapropel S1 deduced from a marine pollen record. Quaternary Science Reviews 27, 832-845. 


\title{
New insights on the tectonics of the Lampedusa Plateau from the integration of offshore, on- land and space geodetic data
}

\author{
Meccariello M. ${ }^{1}$, Ferranti L. ${ }^{1,3}$, Barreca G. ${ }^{1,3}$ \& Palano M. ${ }^{2}$ \\ ${ }^{1}$ Dipartimento di Scienze della Terra, dell'Ambiente e delle Risorse, Università di Napoli Federico II. \\ ${ }^{2}$ Istituto Nazionale di Geofisica e Vulcanologia, Osservatorio Etneo, Catania. \\ ${ }^{3}$ Centro Interuniversitario per l'analisi Sismotettonica Tridimensionale con Applicazioni Territoriali, Chieti Scalo. \\ Corresponding author email: melania.meccariello@unina.it
}

Keywords: Intraplate Paleogene shortening, Lampedusa Plateau, Late Miocene-current strike-slip deformation.

We analyzed the deformation pattern of the Lampedusa Plateau, located in the central sector of the Pelagian Block, through the joint analysis of multichannel seismic reflection profiles calibrated with well-logs, of structural data collected on Lampedusa Island, and of GNSS geodetic velocities of sites on the islands and on the northern shore of the Channel.

Results suggests that this part of the plateau forms an anticlinorium (Lampedusa Plateau Anticlinorium, LPA), which consist of WNW-ESE striking highs and lows, developing during Paleogene to Early Miocene intraplate contraction followed by Miocene to current strike-slip deformation. These broad folds are associated to high-angle faults with a reverse component of displacement (possibly transpressional faults), which cut Eocene to Lower Pliocene strata offshore, and Late Miocene strata on Lampedusa.

Extensional faults, that have a bathymetric expression and are responsible for marked stratal tilting due to their listric geometry, are only found to the NE of the island and are associated to the Pliocene-Quaternary rifting system of the Sicily Channel.

The main growth phase of the LPA occurred during (Late Cretaceous?) Paleocene-Early Miocene $\sim \mathrm{N}-\mathrm{S}$ convergence between Nubia and Eurasia and associated intraplate shortening. Starting from Early Miocene, likely in response to a $\mathrm{CCW}$ rotation of the plate convergence direction, strike-slip deformation occurred with a $\sim \mathrm{NW}$-SE shortening axis and $\sim \mathrm{NE}-\mathrm{SW}$ extension axis. During this time span the previous contractional structures were locally reactivated in transpression.

The extensional and transpressional regimes in the plateau and northeast of it still persist today as documented by geodetic velocities. 


\title{
Crustal deformation and active tectonics in the NW Sicily Channel based on multi-scale analysis of seismic reflection profiles
}

\author{
Meccariello M. ${ }^{1}$, Ferranti L. ${ }^{1} \&$ Pepe F. ${ }^{2}$ \\ ${ }^{1}$ Dipartimento di Scienze della Terra, dell'ambiente e delle Risorse, Università di Napoli Federico II. \\ ${ }^{2}$ Dipartimento di Scienze della Terra e del Mare, Università di Palermo.
}

Corresponding author email: 1ferrant@unina.it

Keywords: Active tectonics, Compression, Sicily Channel.

We propose a reconstruction of the deformational history of the NW Sicily Channel, an important area of deformation within the central Mediterranean Sea, that spans across the offshore prolongation of the Sicilian fold and thrust belt and the Saccense foreland sector (Catalano, 1985; Argnani et al., 1986; Antonelli et al., 1988; Roure et al., 2012; Civile et al., 2014). The research based on the analysis of seismic reflection profiles from the VIDEPI database, industry (ENI) and newly acquired high-resolution sparker profiles.

Starting from Middle Miocene, contractional deformation affected the Egadi area with deep-seated thrustramp. This activity ended $\sim 8 \mathrm{My}$ ago, as evidenced by the high-amplitude reflector associated to the sandy member of Terravecchia formation that seal the deformation. During Late Miocene, a new thrust front developed along the eastern side of the Adventure Bank, partly reactivating an inherited Mesozoic crustal boundary that separated the proximal shelf facies (Trapanese domain) from the distal ramp facies (Saccense domain) in the Miocene Terravecchia foredeep.

The study shows the actual front of the chain is located offshore Capo Granitola. Onshore, a gentle fold affecting Quaternary deposits in the Castelvetrano-Campobello di Mazara area expresses the front continuation (Barreca et al., 2014). During Plio-Pleistocene, the offshore area between Capo Granitola and Sciacca experienced a transcurrent deformation with either normal or reverse component of motion. Contemporarily, in the Egadi area we assist to a transtensional re-activation of normal faults related to the Early Pliocene rift system and a new generation of distributed back-thrust reverse faults, some of which cut the sea-floor.

\section{References:}

Antonelli M., Franciosi R., Pezzi G., Querci A., Ronco G.P., Vezzani F. (1988) - Paleogeographic evolution and structural setting of the northern side of the Sicily Channel. Mem. Soc. Geol. It., 41, 141-157.

Argnani A. Cornini S., Torelli L., Zitellini N. (1986) - Neogene-Quaternary foredeep system in the Strait of Sicily. Mem. Soc. Geol. It., 36, 123-130.

Barreca G., Bruno V., Cocorullo C., Cultrera F., Ferranti L., Guglielmino F., Guzzetta L., Mattia M., Monaco C., Pepe F. (2014) - Geodetic and geological evidence of active tectonics in south-western Sicily (Italy). Journal of Geodyn., 82, $138-149$

Catalano R., D’Argenio B., Montanari L., Morlotti E., Torelli, L. (1985) - Marine geology of the NW Sicily offshore (Sardinia Channel) and its relationships with mainland structures. Boll. Soc. Geo. It., 104(2), 207-215.

Civile D., Lodolo E., Alp H., Ben-Avraham Z., Cova A., Baradello L., Accettella D., Burca M., Centonze J. (2014) Seismic stratigraphy and structural setting of the Adventure Plateau (Sicily Channel). Mar. Geoph. Res., 35, 37-53.

Roure F., Casero P., Addoum B. (2012) - Alpine inversion of the North African margin and delamination of its continental lithosphere. Tectonics, 31(3). 


\title{
Migrazioni e fuoriuscite di fluidi lungo la piattaforma campana settentrionale: osservazioni su profili Chirp e Sparker
}

\author{
Misuraca M. ${ }^{1}$, Budillon F. ${ }^{1}$, Cosentino D. ${ }^{2}$, Ferraro L. ${ }^{1}$, Tonielli R. ${ }^{1}$, Di Martino G. ${ }^{1}$ \& Innangi S. ${ }^{1}$ \\ ${ }^{1}$ Istituto per l'Ambiente Marino Costiero CNR, Napoli. \\ ${ }^{2}$ Università degli Studi Roma Tre, Roma.
}

Corresponding author email: $\underline{\text { samode11@hotmail.it }}$

Keywords: Corpi magmatici sepolti, Risalite di Fluidi, Sismica a riflessione, Zone di accomodamento.

È stata acquisita, a largo della foce del Volturno da l'IAMC-CNR di Napoli, una maglia di sezioni sismiche ad alta risoluzione e dati batimetrivìci multibeam nell'ambito di un programma di monitoraggio ambientale a largo della foce del Fiume Volturno (PON-I AMICA 2013).

I profili Chirp, acquisiti lungo la piattaforma continentale campana settentrionale, hanno consentito il riconoscimento e la successiva modellazione del fondale e della superficie erosiva relativa all'Ultimo Massimo Glaciale. Sono state elaborate carte morfobatimetriche a partire dall'interpolazione dei dati riconosciuti sulla sismica. La morfologia rivelata dalla superficie ottenuta per l'Ultimo Glaciale, nonostante i rigetti minimi delle discontinuità che bordano la struttura, ha rivelato la presenza di quella che è stata interpretata come una zona di accomodamento, definita da un alto strutturale, a direzione E-W, posizionato tra due bacini. Il set di faglie osservato, a direzione NNW-SSE e ENE-WSW, sembra aver controllato in estensione la deposizione dei corpi paralici trasgressivi, osservati su sismica, come testimoniato dalle geometrie esterne, tipicamente cuneiformi. La deformazione osservata è stata correlata cronologicamente, ed in via preliminare, al contemporaneoe ultimo collasso, a terra, della caldera flegrea.

Evidenze di migrazione di fluidi, riconosciute su diverse scale di osservazione e di dataset, hanno reso possibile l'individuazione di un fronte di torbidità acustica con un'orientazione E-W ben definita: un trend ricorrente, osservato per corpi magmatici sepolti e discontinuità strutturali, ampiamente riconosciute anche in letteratura, che ci ha guidato nell'interpretare le evidenze di migrazione e fuoriuscita di fluidi come effetti di un sistema idrotermale che interessa le unità progradanti al margine della piattaforma. La morfologia del fronte di torbidità acustico, inoltre, ha rivelato profili sommitali irregolari con una tipica forma a "denti di sega" probabilmente dovuti alla variabile litologia, e quindi permeabilità, dei corpi sedimentari che costituiscono l'impalcatura del margine. 


\title{
Mappatura a risoluzione sub-metrica e analisi morfometrica di fenomeni di instabilità gravitativa lungo la scarpata meridionale della Sardegna (Mediterraneo Occidentale)
}

\author{
Moriconi R. ${ }^{1}$, Clare M. ${ }^{2} \&$ Lo Iacono C. ${ }^{2}$ \\ ${ }^{1}$ Sapienza Università di Roma. \\ ${ }^{2}$ National Oceanography Centre, University of Southampton, United Kingdom.
}

Corresponding author email: robertomoriconi.rm@gmail.com

Keywords: Analisi morfometrica, AUV (Autonomous Underwater Vehicles), Frane sottomarine.

Questo studio è basato su dati batimetrici e sismici geofisici di risoluzione sub-metrica (Autonomous Underwater Vehicle - AUV, Sub Bottom Profiler - SBP) acquisiti lungo la scarpata meridonale del margine Sardo (Progetto GALSI), usando standards industriali.

In totale sono state riconosciute 490 frane sottomarine in una porzione di fondale larga all'incirca $2,5 \mathrm{~km}$ e lunga poco più di $33 \mathrm{~km}$, che si estende dalla scarpata superiore $(-1000 \mathrm{~m})$ a quella inferiore $(-2700 \mathrm{~m})$. Le frane sono state classificate in base alla larghezza della scarpata principale e in base ai principali parametri morfometrici (l'altezza della scarpata principale e la sua inclinazione, l'inclinazione pre-frana della scarpata, l'azimut, l'area e il volume della zona di distacco e di evacuazione). L'area di studio è stata suddivisa in 3 regioni, in base alla ripidità della scarpata, al fine di confrontare le caratteristiche morfometriche dei tre diversi settori. In secondo luogo, e' stata effettuata un'analisi statistica dei parametri misurati, sia sulle singole regioni, sia sull'area totale di studio. I parametri sono stati finalmente correlati tra loro per analizzare possibili relazioni statistiche tra le varie caratteristiche morfometriche dei lineamenti osservati.

I risultati preliminari di questo studio suggeriscono che il numero delle frane osservate sembra essere funzionale ai cambi di pendenza della scarpata. Le regioni con pendenze maggiori e batimetria irregolare presentano infatti un numero maggiore di fenomeni franosi. Le tre regioni inoltre mostrano per lo più gli stessi coefficienti di correlazione, dimostrando che la natura dei fenomeni franosi rimane invariata in tutta l'area di studio. Inoltre, il substrato Messiniano sub-affiorante nella zona appare come uno dei maggiori fattori di controllo del numero e delle dimensioni dei fenomeni di instabilità gravitativa. Questo studio, basato su una mappatrua dei fondali ad altissima risoluzione, fornisce nuovi input sulle caratteristiche morfometriche dei fenomeni franosi a scala sub-metrica, ancora non pienamente investigati nel campo della ricerca in ambiente marino.

\section{References:}

Masson D.G. et alii (2010) - Large landslides on passive continental margins: processes, hypotheses and outstanding questions. Submarine Mass Movements and Their Consequences (pp. 153-165), Springer Netherlands.

Moscardelli L., Wood L. (2015) - Morphometry of mass-transport deposits as a predictive tool. Geological Society of America Bulletin,B31221.1.

Thomas S. et alii (2010) - Constraining Geohazards to the Past: Impact Assessment of Submarine Mass Movements on Seabed Developments. Submarine Mass Movements and Their Consequences, (pp. 387-398), Springer Netherlands. 


\title{
Effetti del dragaggio di sabbie relitte sui sedimenti superficiali: casi di studio nella piattaforma laziale
}

\author{
Nonnis O., Paganelli D., Pazzini A. \& Proietti R.
}

Istituto Superiore per la Protezione e la Ricerca Ambientale, Roma

Corresponding author email: ornella.nonnis@isprambiente.it

Keywords: Dragaggio, Monitoraggio ambientale, Sabbie relitte.

Il ripascimento con sabbie relitte è considerato da diversi anni un'efficace strumento per combattere l'erosione costiera nonché uno dei metodi più validi per la protezione delle spiagge nell'ambito della gestione integrata.

Il dragaggio di sabbie relitte consente di disporre di grandi quantitativi di sabbia relativamente a basso costo e di buona qualità, con composizione simile a quella delle spiagge attuali e, inoltre, non incide sulla dinamica litoranea. Tuttavia, la loro movimentazione può indurre effetti non trascurabili sull'ambiente marino e deve pertanto essere accompagnata da specifici studi di monitoraggio ambientale. Gli effetti ambientali del dragaggio di sabbie relitte sono stati studiati da ISPRA sin dal 1999 nell'ambito di specifici progetti di monitoraggio condotti per la coltivazione di depositi di sabbie relitte localizzati in Adriatico e in Tirreno. In tale ambito sono state condotte indagini dirette e indirette su morfologia e batimetria del fondo, chimico-fisica dei sedimenti e della colonna d'acqua, particellato sospeso, popolamenti bentonici e ittici demersali.

La notevole quantità di dati acquisiti e il confronto con esperienze extra-Mediterranee ha fornito le basi per creare e proporre un protocollo di monitoraggio ambientale specifico per tali attività (Nicoletti et al., 2009).

In questo lavoro vengono presentati i risultati delle indagini svolte relativamente al comparto sedimento nell'ambito degli studi di caratterizzazione e monitoraggio ambientali connessi al dragaggio di tre depositi sabbiosi localizzati lungo la piattaforma tirrenica laziale (al largo di Anzio, di Montalto di Castro e di Torvaianica).

In ogni sito dragato, subito dopo la movimentazione, è stata osservata una netta variazione granulometrica con la presenza di sedimenti francamente sabbiosi, che con il passare del tempo hanno visto incrementare la frazione fine, imputabile anche alla ripresa, dopo il dragaggio, dell'attività biologica. Nel caso delle aree più intensamente dragate o sottoposte a dragaggi ripetuti, dopo il dragaggio sono stati rilevati sedimenti pelitici, probabilmente per il collasso dei livelli fini sovrastanti e per una più generale instabilità del fondo.

Sulla base degli studi condotti è stato osservato che sebbene l'analisi granulometrica nella maggior parte dei casi permetta di differenziare le aree dragate da quelle non dragate, essa non sempre permette di definire con certezza l'estensione dell'area dragata, per la quale è risultato necessario integrare le analisi granulometriche con le indagini geofisiche (Nonnis et al., 2011).

\section{References:}

Nicoletti L. et alii (2009) - An environmental monitoring proposal related to relict sand dredging for beach nourishment in the Mediterranean sea. In: Journal of Coastal Research, SI 56: 1262-1266.

Nonnis O. et alii (2011) - Physical effects related to relict sand dredging for beach nourishment in the Tyrrhenian sea: the Anzio case. In: Journal of Coastal Research, SI 64: 1380-1384. 


\title{
Geodinamica della trasforme San Paolo nell'Atlantico equatoriale
}

\author{
Palmiotto C. ${ }^{1}$, Ligi M. ${ }^{1}$ \& Bonatti E. ${ }^{1,2}$ \\ ${ }^{1}$ Istituto di Scienze Marine CNR, Bologna. \\ ${ }^{2}$ Lamont Doherty Earth Observatory of Columbia University, New York, USA.
}

Corresponding author email: camilla.palmiotto@bo.ismar.cnr.it

Keywords: Dorsali oceaniche lente, Faglie trasformi oceaniche, Geodinamica.

La zona di frattura San Paolo disloca la Dorsale Medio-Atlantica per circa $580 \mathrm{~km}$. La morfologia di questo dominio trasforme differisce da quella generale delle trasformi "lente" (Fox \& Gallo, 1984), essendo costituito da un sistema di quattro faglie trasformi destre che dislocano due rami di dorsale oceanica e tre piccoli segmenti di accrezione intra-trasformi (Hekinian et al., 2000). La presenza di dorsali intratrasformi all'interno di una zona di frattura oceanica, comune nelle faglie trasformi "veloci", rende l'area di studio particolarmente interessante al fine di comprenderne la loro origine ed evoluzione.

Nella prima fase dello studio è stata condotta un'analisi morfo-batimetrica della regione, a cui è seguita la realizzazione di una carta degli spessori sedimentari mediante l'analisi di profili di sismica a riflessione, e la loro correlazione con carte dei sedimenti pubblicate dall'Istituto di Geologia dell'Accademia di Mosca. Sono poi state realizzate le mappe: 1) dell'anomalia in aria libera; 2) dell'anomalia di Bouguer (MBA); 3) dell'anomalia residua di Bouguer (RMBA); 4) dello spessore crostale. La mappa della MBA mostra un'anomalia negativa al di sotto dei due segmenti di dorsale e della faglia più Settentrionale, delineando una evidente traccia con trend E-W a Nord del dominio San Paolo; inoltre, al di sotto della segmento di dorsale a Nord i valori della MBA sono molto più bassi rispetto a quelli sotto la dorsale Sud. Sottraendo il modello termico calcolato alla MBA, si ottengono i valori della distribuzione della RMBA. E' interessante notare come i valori più negativi siano in questo caso situati al centro del dominio trasforme piuttosto che sotto i rami di dorsale e come questi proseguino verso Est delineando una traccia ben evidente.

Dati geologici e geofisici testimoniano che l'evoluzione strutturale del dominio trasforme San Paolo è stata dominata dal passaggio da una singola zona di frattura ad un sistema di faglie trasformi multiple in seguito alle ripetute riorganizzazioni della geometria del limite di placca Sud America - Africa negli ultimi 58 Ma, con passaggio da una tettonica trascorrente ad una di tipo transpressivo nel settore più occidentale (Maia et al., 2016).

\section{References:}

Fox J.P., Gallo, D. (1984) - A tectonic model for Ridge - Transform - Ridge plate boundaries: implications for the structure of oceanic lithosphere. Tectonophysics, 104, 205-242.

Hekinian R., Juteau T., Gràcia E., Sichler B., Sichel S., Udintsev G., Apprioual R., Ligi M. (2000) - Submersible observations of Equatorial Atlantic mantle: The St. Paul Fracture Zone region. Marine Geophysical Researches, 21, 529-560.

Maia M., Sichel S., Briais A., Brunelli D., Ligi M., Ferreira N., Campos T., Mougel B., Brehme I., Hémond C., Motoki A., Moura D., Scalabrin C., Pessanha I., Alves E., Ayres A., Oliveira P. (2016) - Extreme mantle uplift and exhumation along a transpressive transform fault. Nature Geoscience, 9, 619-624. 


\title{
Un'immagine morfotettonica a scala regionale del bacino di retroarco Tirrenico (Mar Mediterraneo)
}

\author{
Palmiotto C. ${ }^{1}$, Loreto M.F. ${ }^{1}$, D’Angelo S. ${ }^{2} \&$ Fiorentino A. ${ }^{2}$ \\ ${ }^{1}$ Istituto di Scienze Marine CNR, Bologna. \\ ${ }^{2}$ Istituto Superiore per la Protezione e la Ricerca Ambientale, Roma.
}

Corresponding author email: filomena.loreto@bo.ismar.cnr.it

Keywords: Analisi morfotettonica, EMODnet, Tettonica.

Nel corso degli ultimi decenni il Mar Tirreno (Mediterraneo Occidentale) è stato oggetto di numerosi studi geologici e geofisici al fine di ricostruire l'origine e l'evoluzione del bacino di retroarco da esso ospitato. Marani et alii (2004) ha inizialmente proposto una suddivisione del bacino tirrenico in quattro principali domini geodinamici: 1) la provincia Tirrenica Settentrionale, delimitata a Nord dall'Arcipelago Toscano, ad Ovest dalla Dorsale Baronie, ad Est dalle Isole Pontine e a Sud dalla "Selli Line"; 2) il margine passivo della Sardegna Orientale, situato tra la Dorsale Baronie e il rilievo sottomarino Cornacya; 3) il margine attivo Appenninico che caratterizza l'area Tirrenica Meridionale ed Orientale; 4) i bacini oceanici dei vulcani Vavilov e Marsili e le loro rispettive piane abissali, nel Tirreno centrale.

Il lavoro qui presentato è consistito nella realizzazione di una prima mappa morfo-tettonica del Mar Tirreno a scala regionale tramite l'analisi morfo-batimetrica e l'interpretazione di tipo morfo-strutturale di tutto il fondale marino Tirrenico. Sulla base di questa analisi sono state discriminate sette diverse figure morfologiche: 1) scarpata sinistra; 2) scarpata destra; 3 ) asse di bacino allungato; 4) cresta di dorsale di origine non-vulcanica; 5) gomito fluviale; 6) canale abbandonato; 7) meandro abbandonato. Sulla base della distribuzione di questi elementi morfo-tettonici e dei risultati ottenuti dalla proiezione in diagrammi a rosetta dei dati raccolti lungo le scarpate e degli assi di bacini allungati, il Mar Tirreno è stato suddiviso in sei aree principali, ognuna caratterizzata da differenti orientamenti e campi di stress. La nuova carta morfo-tettonica regionale del Mar Tirreno dimostra che l'apertura e l'evoluzione geodinamica del relativo bacino di retroarco potrebbe essere più complicata di quello che generalmente viene descritto in letteratura.

Questo lavoro è stato realizzato durante una collaborazione tra il Servizio Geologico d'Italia- Istituto Superiore per la Protezione e la Ricerca Ambientale e l'Istituto di Scienze Marine-Consiglio Nazionale delle Ricerche di Bologna, nell'ambito del progetto "EMODnet Geology 2". EMODnet (European Marine Observation and Data Network) è un programma supportato e finanziato dalla Commissione Europea, Direttorato Generale degli Affari Marittimi e della Pesca (DG MARE). I dati batimetrici multibeam (scala $200 \mathrm{~m}$ ) sono stati scaricati dal sito di EMODnet (http://www.emodnet.eu/; le isobate (scala $100 \mathrm{~m}$ ) sono state ottenute da Marani et alii (2004).

\section{References:}

Marani M.P., Gamberi F., Bonatti E. (2004) - From seafloor to deep mantle: architecture of the Tyrrhenian backarc basin, 64, SystemCart. 


\title{
Come si forma un delta di stazionamento basso? Stratigrafia e paleoambienti del Delta del Po durante l'ultimo massimo glaciale e implicazioni per lo studio di successioni antiche
}

\author{
Pellegrini C. ${ }^{1}$, Asioli A. ${ }^{2}$, Bohacs K.M. ${ }^{3}$, Drexler T.M. ${ }^{3}$, Sweet M.L. ${ }^{3}$, Maselli V. ${ }^{4}$, Gamberi F. ${ }^{1}$, Rovere M. ${ }^{1}$, \\ Dalla Valle G. ${ }^{1} \&$ Trincardi F. ${ }^{1}$ \\ ${ }^{1}$ Istituto di Scienze Marine CNR, Bologna. \\ ${ }^{2}$ Istituto di Geoscienze e Georisorse CNR, Padova. \\ ${ }^{3}$ Exxon Mobil Upstream Research Company, Spring, Texas, USA. \\ ${ }^{4}$ Department of Geology and Petroleum Geology, University of Aberdeen, United Kingdom.
}

\section{Corresponding author email: claudio.pellegrini@bo.ismar.cnr.it}

Keywords: Cicli Sub-Milanković, Clinotemi deltizi, Quaternario, Stazionamento basso del livello del mare, Variazioni eustatiche.

Le successioni stratigrafiche dei margini continentali rappresentano un importante archivio per la ricostruzione della storia geologica e l'evoluzione dei bacini sedimentari (Nittrouer et al., 2007). In particolare, l'elevato potenziale di risoluzione dei metodi di datazione rende le successioni del Quaternario un archivio ideale per ricostruire con buona precisione le variazioni eustatiche e i cambiamenti paleo climatici (Amorosi et al., 2016).Un aspetto fondamentale nella crescita dei margini continentali è costituito dalla formazione di clinotemi. I clinotemi sono unità sedimentarie caratterizzate da un profilo sigmoidale, formato da strati progradanti verso il bacino (Rich, 1951), che si possono sviluppare a una larga varietà di scale temporali e spaziali. Essi registrano variazioni dei parametri che controllano la loro crescita quali, oscillazione relative del livello del mare, variazione degli apporti sedimentari e cambiamenti oceanografici che interessano la dispersione dei sedimenti (Swenson et al., 2005).

Lo studio di profili sismici ad alta risoluzione, acquisiti in centro Adriatico dall'Istituto di Scienze Marine ISMAR di Bologna, ha messo in luce la successione stratigrafica, costituita da clinotemialimentati dal fiume Po durante le fasi di stazionamento basso del livello del mare dell'ultimo massimo glaciale (Pellegrini et al., 2017). Questa successione stratigrafica mostra singoli clinotemi potenti oltre 100 metri e caratterizzati da una sistematica variazione delle geometrie di strato (topset in particolare) e dei depositi bacinali ad esse associati. Datazioni radiometriche ${ }^{14} \mathrm{C}$ hanno evidenziato che i singoli clinotemi si sono formati in intervalli molto brevi, compresi tra pochi secoli e 4.700 anni, in un intervallo complessivo di circa 17.000 annicompreso tra 31.800 e 14.400 anni (Pellegrini et al., 2017). In questo brevissimo arco di tempo interessato da variazioni eustatiche, climatiche e degli apporti sedimentari, i differenti tipi di clinotemi si sono alternati creando un record stratigrafico potente fino a $350 \mathrm{~m}$ che evidenzia motivi deposizionali stratigrafici simili a quelli di successioni antiche e che sono solitamente attribuite a intervalli deposizionali di più lunga durata (da centinaia di migliaia a milioni di anni) suggerendo che: 1) il tempo di risposta alle variazioni eustatiche e agli apporti sedimentari dei sistemi deposizionali (anche antichi?) sviluppati a scala di margine continentale può essere alla scala dei secoli e millenni; 2) anche clinotemi che si sviluppano alla scala di secoli e millenni possono registrate l'influenza di fattori allogenici; 3) l'accumulo di sedimenti può essere episodico e avvenire in breve tempo, anche in successioni potenti centinaia di metri. Questi concetti possono essere utili per lo studio di record stratigrafici antichi per i quali solitamente sono disponibili tecniche di datazione con una risoluzione nettamente inferiore. 


\title{
Stratigraphy of upper Quaternary contourite drifts and paleoceanographic modeling of the Gulf of Taranto (Ionian Sea, Southern Italy)
}

\author{
Pepe F. ${ }^{1}$, Di Donato V. ${ }^{2}$, Faraci C. ${ }^{3}$, Molisso F. ${ }^{4}$, Dera R. ${ }^{1}$, Ferranti L. ${ }^{2}$, Insinga D.D. ${ }^{4}$, \\ Sacchi M. ${ }^{4} \&$ Passaro S. ${ }^{4}$ \\ ${ }^{1}$ Dipartimento di Scienze della Terra e del Mare, Università di Palermo. \\ ${ }^{2}$ Dipartimento di Scienze della Terra, delle Risorse e dell'Ambiente, Università di Napoli Federico II. \\ ${ }^{3}$ Dipartimento di Ingegneria, Università di Messina. \\ ${ }^{4}$ Istituto per l'Ambiente Marino Costiero CNR, Napoli.
}

Corresponding author email: fabrizio.pepe@unipa.it

Keywords: Bottom currents, Coastal Modeling System Wave, Gulf of Taranto, sea level change, Shallow-water contourite drifts.

Shallow-water contourite drifts are sediments deposited in the water depth range where bottom currents may reflect not only basin-scale thermohaline circulation but also local processes that can be controlled by sea-level changes and morpho-bathymetry.

We investigate these processes in the Gulf of Taranto (Ionian Sea) by integrating, multibeam bathymetric data, gravity core data and high-resolution reflection seismics with Coastal Modeling System Wave and CMS-M2D numerical models. Both geological-geophysical data and numerical modeling coherently indicate that latest Quaternary shallow-water contourite drifts formed in the NW sector of the gulf in response to the eustatic fall of the sea-level that induced a severe impact on the bottom current system. The sea level drop caused subaerial exposure of the summit of the Amendolara Ridge that formed an island off the eastern coasts of Calabria and also created a narrow passageway between the island themselves and the northern Calabria coastline.

Stratigraphic data indicate that the contourite drifts are bounded at the bottom and at the top by two major unconformities, and show that the sediments drifts formed between the onset of the last interglacial and the Early Holocene $(\sim 11,800$ years BP). The analysis of the stratal architecture allows for the recognition of various contourite deposits, depending on the local sea floor morphology, bottom currents and water depth. These are mostly represented by: a) Drift complex, along incision to the NE of the Amendolara Bank; b) Sheeted drifts, along the northeastern slope of the Amendolara Bank; c) Elongate drift along the continental shelf and upper slope offshore the Amendolara village.

Numerical models predict that during the LGM the wave induced currents flow is driven roughly parallel to the northern Calabria paleo-coastline and counterclockwise around the north-eastern flank of the Amendolara Bank. The wave-induced hydrodynamics reaches the maximum velocity of $\sim 0.1 \mathrm{~m} / \mathrm{s}$ that alone was not sufficient to account for the onset of contourite drifts formation. The additional contribution of the basin-scale thermohaline circulation of low Adriatic and Ionian at the wave-induced hydrodynamics created favorable conditions for the occurrence of the contourite drifts. Local erosional features coupled with a substantial lack of contourite deposits is also observed, until the present-day, on the south-eastern flank of the Amendolara Bank, where the LIW flows from the central Ionian Sea towards the Gulf of Taranto. 


\title{
Distribuzione di rifiuti antropici lungo alcuni canyon sottomarini prospicienti le coste italiane: il ruolo dei processi sedimentari e gli impatti sulla fauna marina profonda
}

\author{
Pierdomenico M. ${ }^{1}$, Casalbore D. ${ }^{2}$, Cardone F. ${ }^{3}$, Carluccio A. ${ }^{3}$, Di Bella L. ${ }^{2}$, Frezza V. ${ }^{2}$, \\ D’Onghia G. ${ }^{3} \&$ Chiocci F.L. ${ }^{2}$ \\ ${ }^{1}$ Istituto di Geologia Ambientale e Geoingegneria CNR, Roma. \\ ${ }^{2}$ Dipartimento di Scienze della Terra, Sapienza Università di Roma. \\ ${ }^{3}$ Dipartimento di Biologia, Consorzio Nazionale Interuniversitario per le Scienze del Mare, \\ Unità Locale di Ricerca Università di Bari Aldo Moro.
}

\section{Corresponding author email: martina.pierdomenico@uniroma1.it}

Keywords: Flussi gravitativi, Impatti antropici, Megafauna, Microfauna, Rifiuti marini.

La valutazione degli impatti antropici sugli ecosistemi marini rappresenta una tematica di estrema rilevanza e attualità, data la crescente presenza di infrastrutture in mare e il sempre maggiore sfruttamento delle risorse biotiche e abiotiche. Tra i vari impatti ambientali di origine antropica, l'accumulo di rifiuti nell'ambiente marino è riconosciuto come un fenomeno globale esteso a tutti gli oceani, inclusi gli ecosistemi di mare profondo, per i quali l'entità e gli effetti di tale perturbazione sono ancora in gran parte sconosciuti. Studi a larga scala (Pham et al., 2014; Galgani et al., 2015) hanno evidenziato come il Mediterraneo, un bacino semichiuso caratterizzato da una forte urbanizzazione costiera e da un intenso traffico marittimo, rappresenta un potenziale sito di accumulo per ingenti quantità di rifiuti.

Al fine di aumentare il grado di conoscenza sugli impatti antropici in ambiente marino profondo, nell'ambito del progetto RITMARE è stato effettuato uno studio sulla distribuzione dei rifiuti in alcune aree del settore calabro-siciliano (il Canyon di Gioia e il Canyon di Caulonia, rispettivamente nella Calabria Tirrenica e Ionica, e lo Stretto di Messina), dove sono stati acquisiti video ROV, campioni di sedimento e dati sonar a scansione laterale. La scelta delle aree è stata motivata dal fatto che la testata di questi canyon è ubicata a basse profondità ( $<50 \mathrm{~m}$ ) e soprattutto in corrispondenza di foci di corsi d'acqua a regime torrentizio (fiumare), dove è frequente lo sviluppo di flussi iperpicnali a seguito di eventi alluvionali. In queste aree, si osserva anche una forte antropizzazione del settore costiero spesso associata all'assenza di un'adeguata gestione dei rifiuti solidi. Pertanto, i flussi gravitativi possono determinare il trasporto e la messa in posto di un'elevata quantità di materiale antropico a grande profondità.

Le indagini ROV hanno evidenziato quasi ovunque una presenza cospicua di detrito di origine antropica anche di grandi dimensioni fino ad oltre $-1100 \mathrm{~m}$, derivante sia da attività costiere che marittime. L'area con la più alta concentrazione di rifiuti è il versante siciliano dello Stretto di Messina, dove sono stati osservati grandi accumuli costituiti da rifiuti misti a sedimento e materiale vegetale, che testimonierebbero l'azione di trasporto da parte di flussi gravitativi. Le interazioni tra rifiuti e megafauna sono molteplici e complesse; sebbene in alcuni casi sia evidente un effetto di disturbo sulla fauna da parte del detrito antropico, in altri casi i rifiuti rappresentano un substrato di insediamento o rifugio per alcuni organismi.

Le immagini al microscopio elettronico a scansione di frammenti di plastiche recuperati durante $\mathrm{i}$ campionamenti hanno mostrato come queste siano colonizzate da una ricca microfauna costituita da batteri, briozoi e foraminiferi, sollevando preoccupazioni circa l'eventuale bioaccumulo di microplastiche nelle catene trofiche.

\section{References:}

Galgani F. et alii (2015) - Global distribution, composition and abundance of marine litter. In: Marine anthropogenic litter, Springer International Publishing: 29-56.

Pham C.K. et alii (2014) - Marine litter distribution and density in European seas, from the shelves to deep basins. PLoS One, $9,4:$ e95839. 


\title{
The AD 1908 Messina earthquake and tsunami: causative fault and co-seismic slope failures in the Ionian Sea
}

\author{
Polonia A. ${ }^{1}$, Nelson C.H. ${ }^{2}$, Romano S. ${ }^{1}$, Vaiani S. ${ }^{3}$, Torelli L. ${ }^{4}$, Colizza E. ${ }^{5}$, Gasperini L. ${ }^{1}$, Gasparotto G. ${ }^{3}$, \\ Artoni A. ${ }^{4} \&$ Miserocchi S. ${ }^{1}$ \\ ${ }^{1}$ Istituto di Scienze Marine, CNR, Bologna. \\ ${ }^{2}$ Consejo Superior de Investigaciones Científicas, University of Granada, Spain. \\ ${ }^{3}$ Dipartimento di Scienze Biologiche, Geologiche e Ambientali, Università di Bologna. \\ ${ }^{4}$ Dipartimento di Fisica e Scienze della Terra Macedonio Melloni, Università di Parma. \\ ${ }^{5}$ Dipartimento di Matematica e Geoscienze, Università degli Studi di Trieste.
}

Corresponding author email: alina.polonia@,ismar.cnr.it

Keywords: 1908 Messina earthquake, Ionian fault, Seismo-turbidite, Submarine landslide, Tsunamis.

On December 28 1908, a strong earthquake of estimated $\mathrm{Mw}=7.2$ occurred in the Messina Straits. Within minutes after the earthquake, a tsunami with up to $11 \mathrm{~m}$ of run-up height hits the coasts of Calabria and Sicily. These two events resulted in the destruction of the cities of Messina and Reggio Calabria and the loss of over 60,000 lives. Although it is generally agreed that the earthquake was the result of normal faulting in the Messina Straits, there are uncertainties over the specific location of the causative fault. Several models of seismic source have been proposed but to date, none of them has been able to fully explain the tsunami observations associated with the event (Pino et al., 2009 and reference therein, Billi et al., 2008; Argnani et al., 2009).

We investigated location and geometry of major faults in the Messina strait region using geophysical data at different resolutions.The Ionian Fault, a NW-SE trans-tensional fault located south of the Messina Straits, is accommodating slab tearing and rifting processes. This fault satisfies the requirements of the causative fault for the 1908 earthquake (Polonia et al., 2011; 2016a). Multidisciplinary analyses of sediment cores, including XRF core scanner, now available at ISMAR-CNR, unravelled the effects of the 1908 Messina earthquake on abyssal marine sedimentation. The AD 1908 seismo-turbidite consists of three different stacked turbidite units, suggesting that seismic shaking triggered at least three slope failures from different source areas (Polonia et al., 2016b). These sediment failures can be considered the likely cause, together with coseismic seafloor displacement, for the generation of the AD 1908 tsunami.

\section{References:}

Argnani A., Chiocci F. et alii (2009) - Comment on "On the cause of the 1908 Messina tsunami, southern Italy" by Andrea Billi et al., Geophys. Res. Lett., 36, doi:10.1029/2009GL037332.

Billi A., Funiciello R. et alii (2008) - On the cause of the 1908 Messina tsunami, southern Italy, In: Geophysics Research Letters, 35, 6, Doi:10.1029/2008GL033251.

Pino N.A., Piatanesi A. et alii (2009) - The 28 December 1908 Messina Straits earthquake (Mw 7.1): a great earthquake throughout a century of seismology. Seismological Research Letters, 80, 243-259.

Polonia A., Torelli L. et alii (2011) - The Calabrian Arc subduction complex in the Ionian Sea: regional architecture, active deformation and seismic hazard. Tectonics, 30, TC5018. Doi: 10.1029/2010TC002821.

Polonia A., Panieri G. et alii (2013) - Turbidite paleoseismology in the Calabrian Arc Subduction Complex (Ionian Sea): Geochemistry, Geophysics, Geosystems, 14: 112-140.

Polonia A., Torelli L. et alii ( 2016a) - The Ionian and Alfeo-Etna fault zones: new segments of an evolving plate boundary in the central mediterranean sea?Tectonophysics, 675: 69-90.

Polonia A., Nelson C.H. et alii (2016) b - A depositional model of seismo-turbidites in confined basins based on Ionian Sea deposits.Marine Geology, DOI:10.1016/j.margeo.2016.05.010. 


\title{
The contribution of marine geological studies to reconstruct the Late-Quaternary evolution of Salina Island (Aeolian archipelago)
}

\author{
Romagnoli C. ${ }^{1}$, Casalbore D. ${ }^{2,3}$, Ricchi A. ${ }^{1}$, Lucchi F. ${ }^{1}$, Quartau R. ${ }^{4}$, Bosman A. ${ }^{3}$, Tranne C.A. ${ }^{1}$, \\ Adami C. ${ }^{2}$ \& Chiocci F.L. ${ }^{2,3}$ \\ ${ }^{1}$ Dipartimento di Scienze della Terra e Geologico-Ambientali, Università di Bologna, \\ ${ }^{2}$ Dipartimento Scienze della Terra, Università Sapienza di Roma \\ ${ }^{3}$ Istituto di Geologia Ambientale e Geoingegneria, CNR, Roma \\ ${ }^{4}$ Istituto Dom Luiz, Faculdade de Ciencias, Universidade de Lisboa, Portugal
}

Corresponding author email: claudia.romagnoli@unibo.it

Keywords: Insular shelves, Multibeam bathymetry, Sea-level fluctuations, Volcanic island.

Salina island, in the volcanic Aeolian Arc (Southern Tyrrhenian Sea) represents the emerged culmination ( $\sim 16 \%$ of the total extension) of a large volcanic edifice that reaches $-1300 \mathrm{~m}$ (Romagnoli et al., 2013; Casalbore et al., 2016). In this study, the shallow-water and coastal portions of Salina are analyzed and integrated with field studies, in order to improve our knowledge about the geological evolution of the volcanic edifice. Salina is considered a good case study since submerged insular shelves and raised marine terraces related to lateQuaternary sea-level fluctuations have been widely recognized along its flanks (Lucchi et al., 2013). They are used as indicators of relative paleo sea-levels, providing insights also on the complex history of long-term subsidence and uplift of this volcanic complex. In particular, insular shelves, formed through marine erosion of volcanic centers by sea level fluctuations mainly during stages of reduced or inactive volcanism, provide new constraints for the geological evolution of Salina. The distribution and morphological characteristics of the insular shelves around Salina Island have been analyzed through multibeam high-resolution data and seismic profiles (Sparker $0.5 \mathrm{~kJ}$ ). Shelves having larger widths and deeper shelf edges (over $125 \mathrm{~m} \mathrm{depth}$ ) are considered representative of the original extension of the older volcanic centers that experienced wave erosion (during successive cycles of sea-level fluctuations) and subsidence. Narrower shelves, suggesting a lower evolutionary maturity with respect to the larger ones, are generally observed in the sectors of the islands where younger volcanic products are exposed; they were formed through erosion during the LGM and have been relatively stable since then. Overall, the results show the importance of an integrated study between field volcanologists and marine geologists to unravel the morphological evolution of insular and oceanic volcanoes, providing also insights on the history of vertical movements of the volcanic edifices.

\section{References:}

Casalbore D., et alii, (2016) - Morphological map of Salina offshore (Southern Tyrrhenian Sea). In: Journal of Maps, 12(5), 725-730.

Lucchi F., et alii, (2013) - Eruptive history and magmatic evolution of the island of Salina (central Aeolian archipelago). In: Lucchi, F., et alii (eds) The Aeolian Islands Volcanoes. Geological Society, London, Memoirs, 37, 155-211.

Romagnoli C et alii, (2013) - Bathy-morphological setting of the Aeolian islands. In: Lucchi F., et alii (eds), The Aeolian Islands Volcanoes. Geological Society, London, Memoirs, 37, 27-36. 


\title{
Evoluzione Olocenica e Recente della Piana costiera del fiume Volturno
}

\author{
Ruberti D. ${ }^{1}$, Pepe F. ${ }^{2}$, Sacchi M. ${ }^{3}$ \& Vigliotti M. \\ ${ }^{1}$ Dipartimento di Ingegneria, Università della Campania L. Vanvitelli, Aversa, Caserta. \\ ${ }^{2}$ Istituto per l'Ambiente Marino Costiero CNR, Napoli. \\ ${ }^{3}$ Dipartimento di Scienze della Terra e del Mare, Università di Palermo.
}

Corresponding author email: daniela.ruberti@unina2.it

Keywords: Delta, Piana Costiera, Piana Deltizia, Fiume Volturno, Olocene.

La Piana del Volturno forma un sistema deltizio che si sviluppa presso la foce dell'omonimo fiume in corrispondenza dell'area settentrionale della piana costiera campana (Amorosi et al. 2102; Sacchi et al., 2104). Questo settore costiero peri-tirrenico rappresenta il risultato della morfo-evoluzione Pleistocenica di un ampio semi-graben che ribassa di alcune migliaia di metri le unità meso-cenozoiche del margine occidentale appenninico, secondo una direzione di estensione prevalente NW-SE.

I nostri risultati indicano che la successione stratigrafica del sottosuolo della piana costiera del Volturno e dei fondali marini del corrispondente settore al largo del Golfo di Gaeta, rappresenta il risultato del riempimento sedimentario di una paleo-valle del Volturno incisa all'interno dei depositi piroclastici dell'Ignimbrite Campana (40 ka B.P.), durante le fasi terminali dell'ultimo periodo glaciale. Sulla base dell'analisi stratigrafica di oltre 600 perforazioni a carotaggio continuo eseguite nella piana costiera, è stata ricostruita la morfologia di dettaglio del tetto dell'Ignimbrite Campana, la quale risulta caratterizzata da una profonda depressione, corrispondente all'asse principale della valle incisa, con una generale asimmetria dei fianchi dell'incisione che rispecchia la geometria generale della struttura profonda di questo segmento di catena Sono inoltre riconoscibili, al tetto dell'unità Ignimbritica, una serie di terrazzi di erosione fluviale che testimoniano altrettante fasi di rallentamento/stasi nella discesa e/o risalita del livello del mare durante il Pleistocene superiore - Olocene.

L'integrazione dell'analisi delle facies dei depositi di piana costiera e deltizia con l'interpretazione di profili sismici a riflessione di alta risoluzione (sparker) acquisiti al largo della foce del Volturno ha infine consentito di proporre un modello evolutivo delle associazioni di facies e dei principali elementi deposizionali che include due fasi principali: a) Risalita del livello del mare (>18 ka BP), con rapida inondazione della parte costiera della piana del Volturno e backstepping delle facies deposizionali; b) Termine della fase trasgressiva $(\sim 6.5$ ka BP) ed inizio della progradazione tardo Olocenica. La fase di progradazione, similmente ad altri contesti costieri mediterranei, è accompagnata dalla formazione $(<4.5 \mathrm{ka} \mathrm{BP})$ di un sistema deltizio dominato dalle onde, caratterizzato da barre costiere parzialmente limitanti zone lagunari/lacustri, di cui l'attuale Lago Patria rappresenta una delle aree relitte.

\section{References:}

Amorosi A. et alii (2012) - Late Quaternary incision and deposition in an active volcanic setting: the Volturno Valley Fill, southern Italy.Sediment. Geol., 242, 307-320.

Sacchi M. et alii (2014) - Late-Holocene to recent evolution of Lake Patria, South Italy: An example of a coastal lagoon within a Mediterranean delta system. Global and Planetary Change, 117, 9-27. 


\title{
Preliminary results of the EUROFLEETS2 LGT-GIOIA-77 cruise: Unravelling the complex dynamics of a human-induced landslide which generated the Gioia 1977 tsunami
}

\author{
Sakellariou D. ${ }^{1}$, Chiocci F.L. ${ }^{2}$, Casalbore D. ${ }^{2}$, Ercilla G. ${ }^{3}$, Casas D. ${ }^{3}$, Pierdomenico M. ${ }^{2}$, Lindhorst K. ${ }^{4}$, \\ Maisto F. ${ }^{2}$, Kelner M. ${ }^{5}$, Zavitsanou A. ${ }^{1}$, Pavlidi-Palla M. ${ }^{1}$ \& Manta K. ${ }^{1}$ \\ ${ }^{1}$ Hellenic Centre For Marine Research, Greece. \\ ${ }^{2}$ Dipartimento di Scienze della Terra, Sapienza Università di Roma. \\ ${ }^{3}$ Instituto de Ciencias del Mar, Spain. \\ ${ }^{4}$ Kiel University, Germany. \\ ${ }^{5}$ Pierre \& Marie Curie University, Geoazur, Nice, France.
}

Corresponding author email: francesco.chiocci@uniroma1.it

Keywords: Canyon head, Coastal collapse, Swath bathymetry, Seismic profiles, Dumping, Retrogressive erosion.

The EUROFLEETS2 LGT-GIOIA-77 cruise took place in August 2016 aboard R/V Minerva Uno, with the aim to study and understand the triggering mechanism and controlling factors of the human-induced, submarine landslide which generated the $5 \mathrm{~m}$ high 1977 tsunami waves off the Gioia Tauro harbor. Hullmounted multibeam $(50 \& 300 \mathrm{kHz})$, chirp and sparker $(1500 \mathrm{~J})$ profilers, ROV, gravity corer and dredge have been used during the cruise. Processing and analysis of the different data sets and samples collected during the cruise are in progress. Still some preliminary results allow drawing conclusions on the nature and the failure mechanism of the Gioia landslide.

The Last Glacial Maximum erosional unconformity marks a very prominent element of the seismic stratigraphy below the continental shelf off Gioia Tauro. It truncates the underlying, deformed stratified PlioPleistocene sediments while it is covered by a drape of post-LGM transgressive deposits. Thick, chaotic masses and blocks prevail in the northern part of the survey area. They rest on top of the post-LGM transgressive deposits and rising well above the seafloor. High resolution seismic stratigraphy and dredging revealed the presence of Late Holocene marine muddy sediments on top of the blocks. Consequently, the possible landslide(s) which created the rafted blocks and the chaotic masses predate the deposition of the Late Holocene muddy layer and they are therefore much older than the 1977 Gioia landslide. However, this may not be the case for the blocks which are located very close to coast, as recent information from witnesses indicate significant changes of the littoral prism during the 1977 event.

A morphologically smooth, shallow mound, is located on the northern edge of Gioia Tauro Canyon and is made up of stratified deposits which overlay the chaotic landslide deposits. This is the only place where these stratified deposits have been observed in the survey area and they are the youngest deposits in our area. We suggest that the stratified mound has been formed after the 1977 event by the dumping of the material dredged for the excavation of Gioia Tauro harbor.

In conclusion, the morphology of the area off the Gioia Tauro harbor has changed a lot since the 1977 tsunamigenic landslide, in particular because a huge amount of dredged material has been dumped on the shelf since then. The recent deposits dumping material while the observed scar can't be associated with the 1977 landslide, as previously suggested. The main collapses during the 1977 landslide took place along the littoral prism and the uppermost part of the Gioia Tauro Canyon head. Comparative analysis of detailed morphological mapping and historical maps indicates that the canyon head has been affected by retrogressive erosion during the last 40 years which has modified the 1977 landslide scar. 


\title{
Rodoliti e facies acustiche sonar: il caso di studio dell'Arcipelago Pontino Occidentale, Mar Mediterraneo
}

\author{
Sañé E. ${ }^{1}$, Martorelli E. ${ }^{2} \&$ Chiocci F.L. ${ }^{1}$ \\ ${ }^{1}$ Dipartimento di Scienze della Terra, Sapienza Università di Roma. \\ ${ }^{2}$ Istituto di Geologia Ambientale e Geoingegneria CNR, Roma.
}

Corresponding author email: esaneschepisi@gmail.com

Keywords: Facies sonar, Mar Mediterraneo, Rodoliti.

Rodoliti sono state campionate (733 campioni) al largo dell'arcipelago Pontino occidentale, in 25 stazioni tra i 43 e i 112 m di profondità. Oltre ai campioni algali sono anche disponibili $460 \mathrm{~km} 2$ di dati sonar a scansione laterale. L'obiettivo di questo lavoro è lo studio del rapporto tra rodoliti e facies acustiche. Bennate con rodoliti sono state recuperate prevalentemente nelle facies AB (alto backscatter) (32\% di bennate con rodoliti rispetto al numero totale di bennate nell' $\mathrm{AB}$ ) e AB-D (alto backscatter disomogeneo) (35\% di bennate con rodoliti rispetto al numero totale di bennate nell'AB-D). Considerando la classificazione granulometrica di Folk, si è visto che nelle bennate senza rodoliti il passaggio da basso ad alto backscatter corrisponde al passaggio da sabbie leggermente ghiaiose $(\mathrm{S}(\mathrm{g}))$ a sabbie ghiaiose $(\mathrm{Sg})$. Con $\mathrm{S}(\mathrm{g})$, all'aumento del numero di rodoliti corrisponde il passaggio da facies a basso backscatter a facies ad alto backscatter. Differenze nella granulometria del sedimento sono state osservate tra le due facies dove è stata campionata la maggior parte delle rodoliti, $\mathrm{AB}$ e $\mathrm{AB}-\mathrm{D}$, essendo il sedimento dell' $\mathrm{AB}$ più fine (prevalente $\mathrm{S}(\mathrm{g})$ ) rispetto a quello dell'AB-D (prevalentemente $\mathrm{Sg}$ ). Inoltre, differenze significative nel numero di boxwork e di rodoliti di medie dimensioni sono state trovate tra le facies $\mathrm{AB}$ e AB-D. Considerando anche le facies dove sono state campionate meno rodoliti (basso backscatter disomogeneo, BB-D, alto backscatter con rocce, AB-R, e basso backscatter, BB), differenze significative nelle caratteristiche delle rodoliti (morfologia, struttura e dimensione) vengono rilevate tra le varie facies: pralines piccole "fruticose" sono abbondanti nell'AB, pralines medie "lumpy" e rametti sciolti sono abbondanti nell'AB-D, pralines medie "encrusting-warty" e rametti sciolti sono abbondanti nel BB-D, e boxwork grandi sono abbondanti nell'AB-R e nel BB. Tenendo presente che tutte le bennate con rodoliti sono state recuperate in zone caratterizzate da alto idrodinamismo (le selle tra le isole ed i settori delle isole esposti ai venti predominanti nell'arcipelago, provenienti da ovest), tutte le rodoliti campionate dovrebbero avere caratteristiche simili e coerenti con condizioni di alto idrodinamismo. La variabilità delle rodoliti oltre ad essere legata alle specie costituenti è infatti legata alle condizioni ambientali, ed in particolare all'idrodinamismo. La distribuzione di rodoliti con caratteristiche diverse nelle varie facies identificate suggerisce l'esistenza di un gradiente di energia idrodinamica all'interno delle regioni dell'arcipelago ad alto idrodinamismo dove sono state campionate le rodoliti. Tale gradiente va dalla facies AB (massimo idrodinamismo), all'AB-D, al BB-D, all'AB-R ed infine al BB (minimo idrodinamismo). Infine, è stata calcolata l'area occupata dalle rodoliti (0.2$3.4 \mathrm{~m}^{2}$ ) e quindi la produzione di $\mathrm{CaCO} 3$ da parte delle rodoliti è stata stimata tra i 4 e i $68 \mathrm{~g} \mathrm{CaCO} 3$ all'anno. 


\title{
Le grotte sottomarine del Mediterraneo: peculiarità geobiologiche di un habitat prioritario
}

\author{
Sanfilippo R. ${ }^{1}$, Guido A. ${ }^{2}$, Rosso A. ${ }^{1}$, Belmonte G. ${ }^{3}$, Gerovasileiou V. ${ }^{4}$, Jimenez C. ${ }^{5}$, Hadjioannou L. , \\ Achilleos K. ${ }^{5}$, Russo F. ${ }^{2}$, Kupryianova E. \& Mastandrea A. ${ }^{2}$ \\ Gruppo informale di ricerca Geobiology Marine Caves Group: \\ ${ }^{1}$ Dipartimento di Scienze Biologiche, Geologiche e Ambientali, Catania. \\ ${ }^{2}$ Dipartimento di Biologia, Ecologia e Scienze della Terra, Università della Calabria, Cosenza. \\ ${ }^{3}$ Dipartimento di Scienze e Tecnologie Biologiche ed Ambientali, Lecce. \\ ${ }^{4}$ Institute of Marine Biology, Biotechnology and Aquaculture, Hellenic Centre for Marine Research, Creta, Greece. \\ ${ }^{5}$ Enalia Physis Environmental Research Centre, Cipro.
}

Corresponding author email: $\underline{\text { sanfiros@unict.it }}$

Keywords: Biostalattiti, Carbonati microbici, Olocene, Protula.

Le grotte sommerse del Mediterraneo sono habitat prioritari ancora non del tutto conosciuti. Elementi di pregio geobiologico sono le biostalattiti recentemente descritte in grotte del Mediterraneo dallo Ionio (Puglia: Belmonte et al. 2009, Sicilia: Sanfilippo et al. 2015) al Mar Egeo (Lesbo: Sanfilippo et al. in stampa) e al Bacino di Levante (Cipro: Guido et al. in stampa). Sono biocostruzioni formate dall'interazione fra metazoi con scheletro e comunità di batteri solforiduttori (Guido et al. 2013). Queste complesse strutture biogeniche, che giocano un ruolo importante nel creare nuovi substrati e incrementare la biodiversità, si distribuiscono dalla zona semioscura ai recessi totalmente bui delle grotte. Si accrescono verso il basso dalla volta e obliquamente dalle pareti sviluppando forme coniche o cilindriche lunghe fino a due metri. La superficie esterna mostra un lato più rugoso e uno più liscio in relazione al locale flusso di corrente.

Il framework è formato da grossi tubi carbonatici intrecciati del serpulide Protula, stabilizzati da carbonati microbici, come micriti peloidali, e ricoperti localmente da ossidazioni di Fe-Mn. Il tasso di crescita delle biostalattiti è lento, quelle più antiche hanno un'età di ca. 8000 anni.

Nelle biostalattiti siciliane, di dimensioni decimetriche, il nucleo a Protula è totalmente ricoperto da microbialiti e invertebrati tipici di grotta. E' stato suggerito che le popolazioni pioniere di Protula del nucleo abbiano colonizzato superfici in prossimità di fessure da cui filtravano acque meteoriche e siano state successivamente sostituite da cenosi indicanti un maggiore confinamento a seguito dell'approfondimento relativo dell'area, connesso all'innalzamento eustatico olocenico. Pertanto, la successione di cenosi diverse nelle biostalattiti costituisce un registro fossile della storia recente delle grotte.

Risultati promettenti hanno portato alla istituzione di un gruppo per lo studio della distribuzione delle biostalattiti, forse più tipiche del settore orientale del Mediterraneo, e dei processi biotici e abiotici che ne condizionano diversità e sviluppo nel tempo, in relazione all'evoluzione delle grotte in cui si formano.

\section{References:}

Belmonte G. et alii (2009) - Biogenic stalactites in submarine caves at the Cape of Otranto (SE Italy): dating and hypothesis on their formation. In: Mar Ecol 30: 376-382.

Guido A. et alii (2013) - Pendant bioconstructions cemented by microbial carbonate in submerged marine caves (Holocene, SE Sicily). Palaeo 3 388: 166-180.

Guido A. et alii (in stampa) - Geomicrobiology of the Kakoskali submarine cave (Cyprus, E Mediterranean). In: Facies.

Sanfilippo R. (2015) - Metazoan/microbial biostalactites from present-day submarine caves in the Mediterranean Sea. In: Mar Ecol 36: 1277-1293.

Sanfilippo et alii (in stampa) - Serpulids and bryozoans from submarine caves of the Eastern Mediterranean. In: JMBAUK. 


\title{
Il Tufo Giallo Napoletano nell'architettura stratigrafica del Golfo di Gaeta (Tirreno Meridionale): nuovi dati sismostratigrafici e tefrostratigrafici
}

\author{
Senatore M.R. ${ }^{1}$, Meo A. ${ }^{1}$, Falco M. ${ }^{1}$, Insinga D.D. ${ }^{2}$, Petrosino P. ${ }^{3}$, Di donato V. ${ }^{3}$, Aiello G. ${ }^{2} \&$ Iorio M. ${ }^{2}$ \\ ${ }^{1}$ Dipartimento di Scienze e Tecnologie, Consorzio Nazionale Interuniversitario per le Scienze del Mare, \\ Unità Locale di Ricerca Università del Sannio in Benevento. \\ ${ }^{2}$ Istituto per l'Ambiente Marino Costiero CNR, Napoli. \\ ${ }^{3}$ Dipartimento di Scienze della Terra, dell'Ambiente e delle Risorse, Università di Napoli Federico II.
}

Corresponding author email: senatore@unisannio.it

Keywords: Golfo di Gaeta, Sismostratigrafia, Tefrostratigrafia,Tufo Giallo Napoletano.

Il Tufo Giallo Napoletano (TGN) è stato messo in posto da un evento di tipo pliniano avvenuto ai Campi Flegrei datato $14.9 \pm 0.4 \mathrm{ka}$ (Deino et alii, 2004). I depositi piroclastici emessi, il cui volume stimato è di circa $45 \mathrm{~km} 3$ DRE (Dense Rock Equivalent), hanno ricoperto una superficie di circa $1000 \mathrm{~km}^{2}$. Il Golfo di Gaeta, al margine settentrionale della Campania, si trova a nord dei Campi Flegrei e fa parte di un bacino pliopleistocenico associato all'evoluzione del Tirreno sud-orientale. La sedimentazione in questo settore è stata influenzata dall'attività vulcanica dei Campi Flegrei durante il Pleistocene-Olocene.

I prodotti legati all'eruzione del TGN sono stati correlati, attraverso la piattaforma continentale al largo di Cuma (Aiello et al., 2017), ad un marker stratigrafico (V in Iorio et al., 2014) caratterizzato da analisi tefrostratigrafiche. Nelle sezioni sismiche, $\mathrm{V}$ corrisponde a un riflettore continuo ad alta intensità e pianoparallelo, intercalato ai depositi marini del System Tract Trasgressivo, con profondità dal fondo compresa tra da 10 a $30 \mathrm{~ms}$ (da 8 a circa $25 \mathrm{~m}$ ). Il carotaggio C1161 (profondità $144 \mathrm{~m}$ ), ha recuperato $2.62 \mathrm{~m}$ di sedimenti argillosi e fangosi, con una compattazione stimata di circa il 15\%. L'analisi sismostratigrafica ha permesso di associare la base del carotaggio alla sommità di V. L'analisi tefrostratigrafica del campione alla base del carotaggio ha caratterizzato la parte sommitale del TGN, in termini di litologia e composizione chimica. La composizione dei frammenti di vetro vulcanico estratti ricade lungo il limite tra le trachiti e le fonoliti e quello tra le tefrifonoliti e le latiti, formando un trend composizionale continuo. Le ricerche, ancora in svolgimento, riguardano un carotaggio (C9) eseguito $30 \mathrm{~km}$ a largo della foce del Fiume Garigliano. La frazione di origine vulcanica estratta da un campione a $1.60 \mathrm{~m}$ dal fondo è soprattutto rappresentata da pomici vescicolate, da frammenti di vetro più denso e rari clasti di lava. I clasti di vetro hanno una composizione che ricade lungo il limite tra le trachiti e le fonoliti e quello tra le tefrifonoliti e le latiti. Tenendo conto dell'intervallo di età dedotto da datazioni al radiocarbonio è stata ipotizzata la correlazione tra i due carotaggi.

\section{References:}

Aiello G., Insinga D.D., Iorio M., Meo A., Senatore M.R. (2017) - On the occurrence of the Neapolitan Yellow Tuff tephra in the Northern Phlegraean Fields offshore. Italian Journal of Geosciences, DOI: 10.3301/IJG.2017.06 .

Deino A.L., Orsi G., Piochi M., De Vita S. (2004) - The age of the Neapolitan Yellow Tuff caldera-forming eruption (Campi Flegrei caldera-Italy) assessed by 40Ar/39Ar dating method. Jour.Volcanol. and Geoth.Res., 133, 157-170.

Iorio M., Capretto G., Petruccione E., Marsella E., Aiello G., Senatore M.R. (2014) - Multi-proxy analysis in defining sedimentary processes in very recent prodelta deposits: the northern Phlegrean offshore example (Eastern Tyrrhenian margin, Italy). Rend.Lincei, 25 (2), 237-254. 


\title{
BioGeomorphological control along Mediterranean Beaches
}

\author{
Simeone S. ${ }^{1} \&$ De Falco G. ${ }^{1}$ \\ ${ }^{1}$ Istituto per l'Ambiente Marino Costiero CNR, Oristano.
}

Corresponding author email: simone.simeone@cnr.it

Keywords: Beaches, Seagrass, Geological controls, Sediments

The beach morphology and dynamic are influenced by wave climate, shoreline orientation sediment availability (in terms of nature and sources of sediments) and grainsize. The geological inheritances and the presence of headlands can influences shoaling processes and beach sediment transport, in fact underlying geology influences the morphological evolution of beaches in terms accommodation space for sediments. (Short 2010, Jackson et alii 2005).

Along Mediterranean beaches, the presence of seagrass Posidonia oceanica meadows affect the coastal processes influencing beach dynamics and sediment budget. P.oceanica meadows can affect the morphodynamic state of beaches and the biogenic carbonate production associated with the P.oceanica ecosystem can provide large amount of sediment to beaches and dune. Furthermore leaf litter provided by P.oceanica can play a major role in the exchanges between submerged and emerged beach (Vacchi et alii., 2016;).

In order to determine the role of the biological and geological controls along Mediterranean beaches the relationship among the mentioned factor and the morphology and dynamic of beaches were investigated along coastal tract of about $60 \mathrm{~km}$ along the western Sardinia. This coastal tract is characterized by large linear beaches alternated to embayed beaches and rocky cliffs and by a shoreface constituted by an alternation of shallow rocky outcrops, seagrass meadows and submerged beach sediments.

Data analyzed in this work come from several project and include sedimentological data, single and multibeam data, DGPS and LIDAR data, wave measurement and ecological data (segrass coverage).

Sediment availability is the factor that primary controls beach morphodinamics. Where the amount of terrigenous sediment is high its promote dune and bars formation. The same features can be also present where the production of biogenic carbonate sediment, occurring inside the $P$. oceanica meadow, result high and naturally nourish beach and dune system leading to a positive sediment budget. On the other hand where sediment availability is low the geological controls becomes the major factor that influences beach dynamics leading to a beach rotation as the main short term response. In this case the long term evolution, related to the sea level rise, determine the dynamic of beaches.

Along sheltered beaches the occurrences of P. oceanica meadows close to the shores promote a massive presence of beach cast litter. This litter can built up the body of beaches and of the foredunes and was fund to be the main material that were exchanged between shoreface and beachface.

\section{References:}

Jackson et alii (2005) - Geological control of beach morphodynamic state. In: Marine Geology, 216, $297-314$.

Short A.D. (1999) - Handook of Beaches ad Shoreface Morphodynamics. Wiley, 380 pp.

Vacchi. M. et alii (2016) - Biogeomorphology of the Mediterranean Posidonia oceanica seagrass meadows. In: Earth Surface Processes and Landforms, 42, 42-54. 


\title{
Idrografia e Maritime Capacity Building
}

\author{
Sinapi L. \& Demarte M. \\ Istituto Idrografico della Marina, Genova.
}

Corresponding author email: luigi.sinapi@marina.difesa.it

Keywords: Blue Growth, Dual Use, Hydrographic Organization, Hydrographic Surveyor Category.

L'Idrografia ricopre un ruolo fondamentale nel Maritime Capacity Building in quanto base di tutte le azioni che possono essere svolte in ambito marittimo. Sicuramente chiave sono la crescita e la diffusione della conoscenza attraverso programmi di formazione riconosciuti internazionalmente quali Hydrographic Surveyor Category A level e Category B level rivolti a paesi emergenti che l'Organizzazione Internazionale dell'Idrografia sta promuovendo grazie al supporto degli Istituti Idrografici di diversi paesi tra cui l'Italia con 1'Istituto Idrografico della Marina (IIM). Un interessante aspetto oltre alla formazione è quello inerente alla Blue Growth in cui l'IIM con l'Idrografia si inseriscono in un quadro più ampio sviluppato dalla Marina Militare Italiana con il concetto di Dual Use, secondo un flusso di attività che vedono sempre una doppia capacità del dato di impiego, fruizione e conservazione nella diffusione di una cultura marittima. Nel caso specifico delle unità navali idrografiche le attività si rivolgono alle Scienze Marine con l'Idrografia, l'Oceanografia Fisica, la Geofisica e la Geologia Marina nella protezione degli organismi marini, il monitoraggio dell'ambiente contribuendo concretamente alla Blue Growth e ad una futura crescita dell'economia marittima. Infatti risulta strategico a lungo termine considerare il settore marittimo nella sua complessità e il mare mezzo di trasporto, sorgente di energia di vario tipo, di cibo e nutrienti e in ultimo supporto globale per i traffici. L'Idrografia risulta alla base di attività connesse al mare e supportano la Blue Growth in termini di sicurezza della navigazione e dei commerci, della ricerca scientifica, della gestione di pesca, acquacoltura e ambientale, infrastrutture costiere e portuali, logistica portuale e Maritime Capacity Building. L'International Hydrographic Organization (IHO) si fa promotore di questo obiettivo supportando i paesi costieri in uno sviluppo sostenibile migliorando le loro capacità in ambito idrografico, cartografico e negli obblighi di sicurezza della navigazione contribuendo alla sicurezza della vita in mare e dell'ambiente. Questa azione vede l'IIM in primo piano nello sviluppo di un programma di neo costituzione di un Ufficio Idrografico Nazionale in Libano inserito in un progetto pilota iniziato nel 2014 che terminerà nel 2020 del Ministero Difesa e del Ministero degli Affari Esteri e della Cooperazione Internazionale. In particolare questo progetto non si rivolge solo alla formazione del personale, ma anche all'acquisizione di strumentazioni, di piattaforme e strutture da cui poter realizzare tutto il flusso di lavoro dalla pianificazione alla produzione indipendente di documentazione nautica per la sicurezza della navigazione quali la cartografia nautica elettronica, le carte classiche e le pubblicazioni specifiche. 


\title{
Analisi comparata di metodi di calcolo del run-up per tsunami generati da frana.Casi di studio nel Margine Continentale della Sicilia Settentrionale
}

\author{
Sulli A. ${ }^{1,2}$, Albano L. ${ }^{1} \&$ Zizzo E. ${ }^{1}$ \\ ${ }^{1}$ Dipartimento di Scienze della Terra e del Mare, Università degli Studi di Palermo. \\ ${ }^{2}$ Istituto Nazionale di Geofisica e Vulcanologia, Roma.
}

Corresponding author email: 1udovicoalbano@libero.it

Keywords: Run-up, Tsunami.

Il margine continentale della Sicilia settentrionale è caratterizzato dalla presenza di pericolosità geologiche (sismicità, vulcanismo, risalita di fluidi e movimenti di massa) che espongono questa regione a rischi geologici marini, con potenziale di generazione di tsunami.

Gli tsunami sono onde anomale solitarie legate a movimenti verticali improvvisi dei fondali. Le caratteristiche principali di un'onda anomala sono rappresentate dall'elevata lunghezza d'onda e da un'altezza che varia notevolmente durante la propagazione.

L'obiettivo di questo lavoro è quello di calcolare il run-up associato a tsunami generati da frane. Nel nostro caso sono stati presi in esame due settori della costa settentrionale siciliana, Golfo di Palermo e Golfo di Patti, dove l'analisi di dati geofisici ad alta risoluzione (morfobatimetrici e sismici) mette in evidenza tra gli elementi morfologici numerose frane sottomarine.

In letteratura per calcolare il valore di run-up si usano diversi algoritmi che generalmente hanno come incognita l'ampiezza dell'onda in corrispondenza del punto sorgente. Partendo dalle caratteristiche morfometriche della frana, l'ampiezza viene calcolata attraverso la formula proposta da McAdoo (2004).

In questo lavoro, sono state parametrizzate tutte le frane riconosciute nell'area e di esse sono stati calcolati i valori di run-up di eventuali onde anomale attraverso vari algoritmi (Gedik et al., 2005; Federici et al., 2006; Xi Zhao et al., 2010; Bryant 2008). Queste formule impongono alcune condizioni, che risultano essere "cautelative" sotto il profilo della pericolosità:

1. l'altezza d'onda non subisce variazioni legate alla morfologia della costa;

2. l'energia persa durante la propagazione è zero;

3. l'energia si trasforma istantaneamente da cinetica a potenziale durante la propagazione.

Successivamente è stato calcolato il run-up di frane storiche che hanno effettivamente generato uno tsunami, ed i risultati ottenuti attraverso l'applicazione di queste formule sono stati confrontati con i valori reali. Ciò ha consentito di evidenziare gli algoritmi che descrivono al meglio i fenomeni storici, fornendo uno strumento per orientare la scelta della formula più idonea.

Infine, dall'analisi grafica della relazione tra valori di run-up ed ampiezza d'onda in prossimità del punto sorgente è stata estrapolata una funzione utile per calcolare il run-up in maniera speditiva.

\section{References:}

Bryant E. (2008) - Tsunami, The Underrated Hazard. Springer, 167-178.

Federici B. et alii, (2006) - Analisi del rischio tsunami applicata ad un tratto della costa Ligure. Geomatics Workbooks, n. 6.

Gedik N. et alii (2005) - Laboratory investigation on tsunami run-up. Ocean Engineering 32, 513-528.

McAdoo B.G., Watts P. (2004) - Tsunami hazard from submarine landslides on the Oregon continental slope. Mar. Geol. $203,235-245$.

Zhao X. et alii (2010) - Propagation and runup of tsunami waves with Boussinesq model. Proceedings of the 32nd International Conference on Coastal Engineering, Shanghai. 


\title{
Marine Surveys for industry in challenging environments
}

\author{
Taliana D. ${ }^{1} \&$ Cecchini S. ${ }^{1}$ \\ ${ }^{1}$ Fugro Oceansismica S.p.A., Roma.
}

Corresponding author email: d.taliana@fugro.com

Keywords: Adaptability, Geology, Geophysics, Human Resources, Marine Sciences.

Deepwater and Ultra-Deepwater environments (>5000 feet of water depth) and high latitude areas are recognized as the last unexplored zones of the world, where Oil, Gas and natural resources remain to be discovered and produced.

During the last 15 years, the Oil\&Gas Industry was able to expand significantly to work in challenging environments thanks to technological development and to the human adaptability.

The marine survey in challenging environments is normally related with:

- Oil and Gas exploration

- Gas Hydrates research

- Polymetallic nodules research

- Rare earth metals research

- UNCLOS (United Nations Convention on the Law of the Sea) and EEZ (Exclusive Economic Zone) survey Many Services Companies, like Fugro, are used to work in challenging environments with motivated teams that are trained to deal with:

- adverse weather conditions

- absence of close facilities due to the distances of the survey areas from shore ( $>3$ navigation days from closest harbour)

- risk of piracy

- several weeks with poor food choices

- poor hygenic conditions

These difficult working conditions can be endured by extremely adaptable personnel, with the support of a strong organization behind.

The Fugro office in Rome carried through several projects in challenging environments. Among these, an example is the acquisition of 2D Seismic Data carried out in 2012 on the Tanganyika Lake (Tanzania), the second largest and deepest freshwater lake in the world.

For this project, Fugro had the need to deploy a proper seismic vessel to perform the survey, but the only boat available on the lake was an old rusty ferry boat, abandoned on a beach. Fugro decided to accept the challenge: after 7 months of remodelling and refurbishing, the Old Mwongozo Ferry Boat turned into a new life, and 3 months later $2100 \mathrm{~km}$ of 2D Seismic Lines were acquired in one of the most interesting geological areas of the world: A Rift Lake.

This project was certainly the most challenging, but not the only one. Fugro people are accustomed to deal with "unconventional projects" that push them to test their strength, adaptability and endurance.

Other challenging projects of the last few years were:

- Canada (Offshore Labrador) and Kara Sea (North of Siberia) where Fugro teams were embarked for 2 months without crew change and at a distance of days from the closest harbor.

- Offshore East and West Africa where pirate attacks and the tropical diseases are very common.

- Strait of Magellan with its well-known strong blizzards.

- Bosporus and Dardanelles Channels, where the intense maritime traffic is a serious concern and everywhere there are obstructions to deal with during the seismic acquisition with long streamers (i.e. platforms/ infrastructures, fishing nets and fishing boats).

Thanks to the teamwork, the Project Management and the Offshore Survey and the processing and interpretation teams, high quality results are achieved, focusing on the Client needs but also permitting to improve scientific knowledge. 


\title{
Ricostruzione del forzante termoalino durante la formazione del sapropel S1
}

\author{
Tesi T. ${ }^{1}$, Asioli A. ${ }^{2}$, Minisini D. ${ }^{3}$, Maselli V. ${ }^{4}$, Dalla Valle G. ${ }^{1}$, Gamberi F. ${ }^{1}$, Langone L.. , Cattaneo A. , \\ Montagna P. ${ }^{1} \&$ Trincardi F. ${ }^{1}$
}

${ }^{1}$ Istituto di Scienze Marine CNR, Bologna.

${ }^{2}$ Istituto Geoscienze e Georisorse CNR, Padova.

${ }^{3}$ Shell International Exploration and Production Inc, Houston, USA.

${ }^{4}$ Department of Geology and Petroleum Geology, University of Aberdeen, United Kingdom.

${ }^{5}$ Institut Français de Recherche pour l'Exploitation de la Mer, Géosciences Marines-Exploration et exploitation Durable des Ressources Océaniques Minérales et Energétiques, Plouzané, France.

Corresponding author email: tommaso.tesi@bo.ismar.cnr.it

Keywords: Anossia, Circolazione termoalina, Mar Adriatico, Mar Mediterraneo Sea, Sapropel S1.

Questo studio ricostruisce i processi che hanno determinato lo sviluppo dell'anossia nei sedimenti del Mar Adriatico durante la formazione del sapropel più recente (S1, ca. 7-10 ky BP). Attraverso untransetto di carote recuperate dalla piattaforma al bacino profondo è stato possibile caratterizzare il forzante oceanografico che ha favorito la stagnazione al fondo. I nostri risultati, che comprendono dati geochimici (organici e inorganici), ecologici e sedimentologici, indicano che la formazione del sapropel S1 coincide con la brusca interruzione della Northern Adriatic Deep Water (NADW). Il quadro generale a livello di Mediterraneo Orientale suggerisce una serie di eventi concatenati in cui l'intensificazione dei monsoni africani, a cui si è susseguito l'indebolimento delle Levantine Intermediate Waters (i.e., addolcimento dovuto all'input del Nilo), ha ostacolato il precondizionamento delle acque nord Adriatiche necessario per la formazione della NADW in inverno. I nostri risultati sottolineano quindi (i) l'importanza dell'Adriatico per la ventilazione del Mediterraneo orientale e (ii) l'implicito legame fra le maggiori masse di acque la cui destabilizzazione ha esercitato controllo primario sulla concentrazione dell'ossigeno al fondo. 


\title{
Interazioni Terra-Mare e Hazard. Conservazione delle strutture antropiche e riqualificazione Ambientale: un caso studio
}

\author{
Tessarolo C. ${ }^{1,2}$, Ciaccio G. ${ }^{1}$, Corrias N. ${ }^{1}$, Nemola A. ${ }^{1}$, Sorce R. ${ }^{1} \&$ Di Grigoli G. ${ }^{1,3}$ \\ ${ }^{1}$ Geological \& Biological Team LTD. \\ ${ }^{2}$ Dipartimento di Scienze dell'Ambiente e della Terra, Sezione Scienze Geologiche e Geotecnologie, \\ Università degli Studi di Milano-Bicocca. \\ ${ }^{3}$ Dipartimento di Scienze della Terra e del Mare, Università degli Studi di Palermo.
}

\section{Corresponding author email: g.digrigoli@gbtoffshore.com}

Keywords: Conservazione Infrastrutture, Densità Soundings, Instabilità Costiera, Modificazione Costiera, Survey ad Alta Risoluzione.

Nell'ambito delle opere di sistemazione delle infrastrutture e riqualificazione ambientale della costa di Santa Marina Salina (Isole Eolie), volte particolarmente alla salvaguardia del centro abitato tra Punta Lamie and Passo Megna, sono stati effettuati dei rilievi geofisici nell'estate 2016. L'indagine ha interessato circa 500 $\mathrm{m}$ di tratto costiero, a fronte di due opere di difesa marina rappresentate da una barriera emersa ed una soffolta, ed estendendosi verso largo per circa $150 \mathrm{~m}$. L'area indagata è compresa tra $-1 \mathrm{e}-50 \mathrm{~m}$.

Il multibeam utilizzato è un Norbit iWBMS, uno strumento compatto equipaggiato con un sistema inerziale (Applanix), un sistema GNSS e una sonda di velocità integrata. Il sistema utilizza frequenze modulate tra 200 e $700 \mathrm{kHz}$ per restituire dati batimetrici ad alta risoluzione. L'ampiezza del ventaglio di acquisizione tra $7^{\circ}$ e $210^{\circ}$ consente di registrare dati verso il basso e lateralmente fino in prossimità dell'interfaccia aria-acqua, con un angolo tra i beam di $0.5^{\circ}$ sia lungo che trasversalmente la rotta investigata a $700 \mathrm{kHz}$. Per assicurare un'elevata risoluzione nella mappatura dei blocchi della scogliera soffolta e delle condizioni al contorno, durante il rilievo è stato impostato il metodo equidistance, che performa una densità costante di beam durante l'acquisizione. Ciò ha consentito di elaborare modelli digitali del terreno con una risoluzione variabile in funzione della profondità e cella compresa tra $0.10 \mathrm{~cm}$ e $0.25 \mathrm{~cm}$, in grado di evidenziare la presenza di blocchi antropici in corrispondenza della testata e delle pendici prossimali di un canyon, posto in prossimità della costa e connesso al sistema di drenaggio fluviale a terra.

La presenza di interazioni terra-mare lungo costa è ampiamente documenta lungo la penisola italiana e le sue isole (Tessarolo et al., 2008; Taviani et al., 2015), dove sistemi di canyon estendono le loro testate fino alla zona costiera, causandone modificazioni anche profonde.

Spesso l'istallazione di strutture antropiche non tiene conto delle possibili connessioni naturali tra entroterra, sistema costiero e sistema marino, determinando la modificazione e talora l'intensificazione del regime energetico locale.

In tal caso in particolare, la presenza del canyon interconnesso al regime fluviale, costituisce una via preferenziale di trasporto ad alta energia, in grado di dislocare in poco tempo i blocchi delle barriere antropiche costruite lungo costa. Uno studio integrato profondo a livello geomorfologico risulta quindi essenziale per comprendere le interazioni terra-mare, e pianificare, realizzare e riqualificare ogni tipologia di intervento costiero con finalità antropiche ed ambientali.

\section{References:}

Taviani M. et alii (2015) - The "Sardinian cold-water coral province " in the context of the Mediterranean coral ecosystems. Deep Sea Research II. http://dx.doi.org/10.1016/j.dsr2.2015.12.008

Tessarolo C. et alii (2008) - Preliminary data concerning the morphology of a Calabrian Ionian margin area: Caulonia and Marina di Gioiosa canyons. Chemistry and Ecology, 24, 225-242. 


\title{
Nuovi risultati delle indagini geofisiche sull'Isola di Linosa
}

\author{
Tonielli R. ${ }^{1}$, Innangi S. ${ }^{1}$, Di Martino G. ${ }^{1} \&$ Giardina F. ${ }^{2}$ \\ ${ }^{1}$ Istituto per l'Ambiente Marino Costiero, CNR, Napoli. \\ ${ }^{2}$ Area Marina Protetta Isole Pelagie, Lampedusa.
}

Corresponding author email: renato.tonielli@,cnr.it

Keywords: Biocostruzioni, Indagini dirette, Morfo-batimetria.

Nel mese di Agosto 2016 l'Istituto per l'Ambiente Marino Costiero (IAMC - CNR) ha svolto una campagna oceanografica per la realizzazione della carta dei fondali dell'Isola di Linosa in relazione alla convenzione "Realizzazione di Attività di ricerca e Monitoraggio nell'Area Marina Protetta Isole Pelagie" (Tonielli e Innangi, 2017).

I rilievi sono stati finalizzati alla mappatura dei fondali per la definizione delle biocenosi prioritarie ed hanno previsto acquisizioni morfo-batimetriche (i.e. De Falco et al., 2010; Innangi et al., 2015; Tonielli et al., 2016) a cui sono state associate campionature dirette per la caratterizzazione dei fondali e il riconoscimento delle facies acustiche (i.e. Kloser et al., 2010; Parnum et al., 2004; Preston et al., 2001).

I rilievi hanno interessato sia le aree dell'Area Marina Protetta (AMP), sia una vasta area esterna ai limiti dell'AMP, in un range di profondità compreso tra i 10 ed i 900 metri; l'acquisizione morfo-batimetrica è stata effettuata con due differenti Multibeam ad alta risoluzione (Reson SeaBat 7125 - Reson SeaBat 7160) mentre le indagini dirette hanno previsto prelievi tramite benna e visione diretta del fondo mediante un Remotely Operated Vehicle (ROV) dotato di telecamera ad alta risoluzione.

Viene qui presentato il risultato della elaborazione del dataset batimetrico, su cui sono visibili numerose strutture riconducibili alla natura vulcanica dell'isola, ed i video delle calate ROV che hanno rivelato la presenza di aree ricche di biocostruzioni, caratterizzate in alcuni casi da una copertura totale di Lithophyllum con presenza di spugne, briozoi, idrozoi e distribuzioni molto diffuse rodoliti e mäerl.

\section{References:}

De Falco G., Tonielli R., Di Martino G., Innangi S., Simeone S., Parnum I.M.,(2010) - Relationships between multibeam backscatter, sediment grain size and Posidonia oceanica seagrass distribution. In: Cont. Shelf Res. 30, 1941-1950. doi:10.1016/j.csr.2010.09.006.

Innangi S., Barra M., Di Martino G., Parnum I.M., Tonielli R., Mazzola S. (2015) - Reson SeaBat 8125 backscatter data as a tool for seabed characterization (Central Mediterranean, Southern Italy): Results from different processing approaches. In: Appl. Acoust. 87, 109-122. doi:10.1016/j.apacoust.2014.06.014.

Kloser R.J., Penrose J.D., Butler a. J., (2010) - Multi-beam backscatter measurements used to infer seabed habitats. In: Cont. Shelf Res. 30, 1772-1782. doi:10.1016/j.csr.2010.08.004.

Parnum I.M., Siwabessy P.J.W., Gavrilov a N., (2004) - Identification of seafloor habitats in coastal shelf waters using a multibeam echosounder. In: Acoust. 2004.

Preston J.M., Christney A.C., Bloomer S.F., Beaudet I.L., (2001) - Seabed Classification of Multibeam Sonar Images. In: OCEANS, 2001. MTS/IEEE Conference and Exhibition. Honolulu, HI, pp. 2616-2623. doi:10.1109/ OCEANS.2001.968411.

Tonielli R., Innangi S. (2017) - Relazione finale della Campagna Oceanografica “Linosa”. doi:8361TR2017. 


\title{
Depositi di frana e colata sottomarina nel bacino della corsica (mar tirreno)
}

\author{
Tramontana M. ${ }^{1,2}$, Baioni D. ${ }^{1} \&$ Savelli D. ${ }^{1,2}$ \\ ${ }^{1}$ Dipartimento di Scienze Pure e Applicate, Università degli Studi di Urbino Carlo Bo. \\ ${ }^{2}$ Consorzio Nazionale Interuniversitario per le Scienze del Mare, Roma.
}

Corresponding author email: mario.tramontana@uniurb.it

Keywords: Bacino della Corsica, Depositi di frana e colata sottomarina, Mar Tirreno.

Il Bacino della Corsica si estende in direzione N-S tra il margine orientale corso e la Dorsale dell'Elba. Al suo interno si individuano due aree depocentrali principali, separate da una sella batimetrica che si sviluppa in corrispondenza del $42^{\circ}$ parallelo N. Si tratta di due depressioni di cui quella meridionale (Bacino di Solenzara) è più ampia e profonda di quella settentrionale.

Il Bacino della Corsica corrisponde nel suo insieme a un'ampia depressione sinclinalica, con marcata asimmetria nella parte settentrionale, contenente alcune migliaia di metri di sedimenti e che si raccorda verso E con l'ampia struttura anticlinalica della Dorsale dell'Elba (AA.VV., 1979). I sedimenti più superficiali, del Pleistocene terminale-Olocene, campionati tramite carotaggi, sono caratterizzati da fango grigio bruno di natura prevalentemente torbiditica che, superiormente, passa al fango ocraceo che ricopre il fondale.Nel bacino sono stati riconosciuti, sulla base dell'interpretazione di profili sismici ad alta risoluzione (SBP 3,5 KhZ), diversi corpi deposizionali anche di grandi dimensioni, sempre sepolti, interpretati come depositi di frane e colate sottomarine (cfr. Wezel et al., 1982). Si tratta di accumuli caratterizzati da una risposta acustica omogenea: la massa coinvolta è infatti di norma trasparente e solo in certi casi, nelle aree più prossime alle zone di distacco dei materiali, si osservano deboli riflessioni interne irregolari e discontinue. Geometricamente questi depositi costituiscono corpi lenticolari, per lo più irregolari e con superfici sommitali ricche di micro e macroasperità, ricoperti e talora livellati dai sedimenti fangosi sovrastanti.L'accumulo principale, interpretato nella parte più al largo come colata, si ubica nel Bacino di Solenzara, alla base della scarpata della Corsica e si estende in direzione N-S per $25-30 \mathrm{~km}$ e in direzione E-W per $15-20 \mathrm{~km}$. Lo spessore non è sempre valutabile in quanto la base non è sempre visibile. Il valore massimo osservato è di circa $40 \mathrm{~m}$. Lo spessore dei sedimenti che ricoprono l'accumulo è variabile, da $2-4 \mathrm{~m}$ a circa $30 \mathrm{~m}$. Il senso di movimento è da W verso E o da WSW a ENE. La posizione stratigrafica dei depositi permette di riconoscere una accentuata instabilità dei sedimenti sui margini del bacino, soprattutto sul Margine Corso, probabilmente riferibile al Pleistocene superiore. L'innesco dei fenomeni di instabilità sarebbe stato favorito dall'abbassamento del livello marino nell'ultimo glaciale.

\section{References:}

AA.VV. (1979) - Primi dati geologici sul Bacino della Corsica (Mar Tirreno). In: Atti del Convegno Scientifico Nazionale Progetto Finalizzato Oceanografia e Fondi Marini, Roma 1979, pp. 713-727.

Wezel F.-C. et alii (1982) - Sedimentazione sui margini tirrenici in relazione alla loro evoluzione tettonica. In: Mem. Soc. Geol. It., 24: 401-426. 


\title{
Ricostruzione della superficie erosiva dell'ultimo massimo glaciale nell'area del Mar Piccolo (Taranto)
}

\author{
Valenzano E. ${ }^{1}$, Scardino G. ${ }^{3}$, Cipriano G. ${ }^{1}$, Fago P. ${ }^{3}$, Capolongo D. ${ }^{1}$, De Giosa F. ${ }^{4}$, Lisco S. ${ }^{1}$, \\ Mastronuzzi G. ${ }^{1} \&$ Moretti M. ${ }^{1}$ \\ ${ }^{1}$ Dipartimento di Scienze della Terra e Geoambientali, Università degli Studi di Bari. \\ ${ }^{2}$ Dipartimento di Biologia, Università degli Studi di Bari. \\ ${ }^{3}$ Consorzio Nazionale Interuniversitario per le Scienze del Mare, Roma. \\ ${ }^{4}$ Coastal Consulting and Exploration, Bari.
}

Corresponding author email: eliana.valenzano@uniba.it

Keywords: High-resolution seismic imagery, Holocene, Paleo-valley, Taranto.

L'area del Mar Piccolo di Taranto è riconosciuta ormai da diversi anni come area chiave per lo studio delle successioni e dei marker stratigrafici dell'ultimo interglaciale (Negri et al.,2014; Mastronuzzi e Sansò, 2002). Meno conosciute sono invece le dinamiche sedimentarie e l'assetto stratigrafico di questo bacino interno nel corso dell'Olocene. Inoltre, le differenti ipotesi sulla genesi e sull'evoluzione morfologica recente del Mar Piccolo, sono generalmente basate su un record di dati non adeguato.

Nuovi dati di sismica monocanale ad alta ed altissima risoluzione, acquisiti su linee fittamente spaziate e validati da un sondaggio terebrato fino alla profondità di $45 \mathrm{~m}$ dal fondo mare, hanno permesso di indagare l'architettura stratigrafica dei sedimenti più recenti del Mar Piccolo.

I profili sismici mettono in luce la presenza di una chiara superficie erosiva che tronca l'unità stratigrafica informale delle argille subappennine (Pliocene superiore - Pleistocene inferiore-medio). L'unità sovrastante, generalmente in discordanza angolare, è costituita da una successione di limi olocenici con alternanze di sedimenti più grossolani alla base che può raggiungere uno spessore di $46 \mathrm{~m}$.

Geometria e morfologia della superficie, ricostruite tramite l'interpolazione di un DEM, sembrano suggerire la presenza di una valle incisa presumibilmente durante l'ultimo glaciale. Il calcolo delle direzioni di flusso effettuato sul DEM mostra linee di impluvio compatibili con l'attuale reticolo di drenaggio.

Mastronuzzi G., Sansò P. (2002) - Pleistocene sea level changes, sapping processes and development of valleys network in Apulia region (southern Italy). Geomorphology, 46, 19-34.

Negri A., Amorosi A., Antonioli F., Bertini A., Florindo F., Lurcock P.C., Marabini S., Mastronuzzi G., Regattieri E., Rossi V., Scarponi D., Taviani M., Zanchetta G., Vai G.B. (2014) - A potential global boundary stratotype section and point (GSSP) for the Tarentian Stage, Upper Pleistocene, from the Taranto area (Italy): Results and future perspectives. Quat. Int. 383, 145-157. 


\title{
Neogene tectono-sedimentary interaction between the calabrian accretionary wedge and the apulian foreland in the northern ionian sea
}

\author{
Volpi V. ${ }^{1}$, Delben A. ${ }^{2}$, Civile D. ${ }^{1} \&$ Zgur F. ${ }^{1}$ \\ ${ }^{1}$ Istituto Nazionale di Oceanografia e di Geofisica Sperimentale,Trieste. \\ ${ }^{2}$ Dipartimento di Matematica e Geoscienze, Università di Trieste.
}

\section{Corresponding author email: vvolpi@inogs.it}

Keywords: Apulian Platform, Calabrian Accretionary Wedge, Ionian Sea,Transpressional tectonics.

The structural setting of the northern Ionian Sea is characterized by the collision of the Calabrian Accretionary Wedge (CAW) with the adjacent foreland domains (the Apulian and Pelagian continental blocks), as a result of the northwestern subduction of the Ionian slab (Malinverno \& Ryan, 1986; Guegen et al., 1997). The Ionian lithosphere is laterally confined by two major structural features, the Malta escarpment to the southwest and the Apulia escarpment to the northeast. While the central and southwestern sectors of the CAW have been largely investigated, the northeastern portion still remain less explored and defined, mainly due to the lack of offshore exploration wells to calibrate seismic data.

New multichannel seismic and bathymetric datasets, recently acquired with the R/V OGS Explora in the $\mathrm{N}$-Ionian Sea (Salento offshore), integrated with existing data, covers with a higher detail this collisional area. In our seismo-stratigraphic recostruction, the outermost sector of the CAW in the investigated area would likely represent an independent block of the Apulian platform, involved in the compression of the wedge, as suggested by the presence of peculiar seismic facies below the Messinian reflector in the frontal portion of the CAW, also identified and differently described by Butler (2009). The presence of an unconformity within the Plio-Quaternary succession on both the CAW and the Apulian foreland led us to hypothesize that the oblique and diachronous collisional system, started in lower Pliocene, was then re-activated in a generic mid-Pliocene which represented the main tilting phase of the Apulian foreland. More recently, transpressional tectonics affected the outer part of the CAW resulting in the uplift of the independent block of the western Apulian foreland, the so-called "Transpressed Apulian Block" (TAB). We suggest that for the orientation and position of this structure it could be correlated to the Amendolare/Pollino ridge, presents further to the north in the Gulf of Taranto (Ferranti et al., 2014); thus the old margin of the Apulian platform would represent the eastern tectonics release zone that guided and partecipated to the migration of the CAW towards south-east.

\section{References:}

Butler, R.W.H., (2009) - Relationship between the Apennine thrust belt, foredeep and foreland revealed by marine seismic data, offshore Calabria. In: Boll Soc Geol It 128(2), 262-278.

Ferranti L., Burrato P., et alii, (2014) - An active oblique-contractional belt at the transitionbetween the Southern Apennines and Calabrian Arc:The Amendolara Ridge, Ionian Sea, Italy. In: Tectonics, 33: 2169-2194.

Gueguen E., Doglioni, C., et alii, (1997) - Lithospheric boudinage in the western Mediterranean back-arc basin. In: Terra Nova 9, 184-187.

Malinverno, A., Ryan, W.B.F., (1986) - Extension in the Tyrrenian Sea and shortening in the Apennines as a result of arc migration driven by sinking of the lithosphere. In: Tectonics, 5, 227-245. 


\title{
Sismotettonica del Margine Continentale della Sicilia nord-occidentale: implicazioni per la valutazione del geohazard
}

\author{
Zizzo E. ${ }^{1}$, Sulli A. ${ }^{1,2}$ \& Morticelli M.G. ${ }^{1}$ \\ ${ }^{1}$ Dipartimento di Scienze della Terra e del Mare, Università di Palermo. \\ ${ }^{2}$ Istituto Nazionale di Geofisica e Vulcanologia, Roma.
}

Corresponding author email: elisabetta.zizzo@unipa.it

Keywords:Geohazard, Margine continentale, Sismicità, Sismotettonica, Tettonica attiva.

I processi tettonici attivi nel margine continentale della Sicilia settentrionale (MCSS) sono stati analizzati per la realizzazione della carta sismotettonica, al fine di ottenere uno strumento utile per la valutazione della pericolosità sismica della regione.

La carta sismotettonica è realizzata attraverso la sovrapposizione di layer che rappresentano la distribuzione di tematismi, quali litostratigrafia, tettonica, sismicità, flussi di calore, gravimetria, magnetometria, profondità della Moho, movimenti orizzontali e verticali, frane, fuoriuscite di fluidi, evidenziando la relazione tra questi e le strutture attive.

Il MCSS si trova in una zona di transizione tra la catena siciliano-maghrebide a sud e il bacino tirrenico di retro-arco a nord, dove la profondità della Moho varia da circa $10 \mathrm{~km}$ nella piana del Marsili, a circa $40 \mathrm{~km}$ verso le coste nord siciliane. Le anomalie di Bouguer passano da valori di $180 \mathrm{mGal}$ nel Tirreno ad anomalie negative nella Sicilia centrale $(-100 \mathrm{mGal})$, mentre anomalie magnetiche positive caratterizzano gli edifici vulcanici, anche sommersi o sepolti. I valori di flusso di calore sono elevati nel Tirreno $\left(200 \mathrm{~mW} / \mathrm{m}^{-2}\right)$ e diminuiscono (30-40 $\left.\mathrm{mW} / \mathrm{m}^{-2}\right)$ verso l'avampaese.

Nel MCSS si possono distinguere diversi volumi sismogenetici, sia superficiali che profondi. La sismicità profonda, relativa alla subduzione ionica, è presente nella parte orientale del margine, quella superficiale è invece il risultato della deformazione fragile della catena maghrebide. Nel settore occidentale gli eventi superficiali si verificano lungo una fascia a direzione $\mathrm{E}-\mathrm{W}$, con meccanismi focali in accordo con una deformazione compressiva NW-SE. Verso Est la sismicità è legata a sistemi di faglie distensive e trascorrenti destre NWSE. Durante gli ultimi 125 ky l'attività tettonica è evidenziata da movimenti verticali, che mostrano una diminuzione da E a W; inoltre, mentre i settori continentali sono sollevati, le aree offshore sono in subsidenza, suggerendo l'esistenza di movimenti verticali differenziali. I valori di GPS documentano la deformazione attiva con movimenti differenziali di singoli blocchi verso i quadranti settentrionali, in accordo con la sismicità superficiale, e la convergenza tra Sicilia e Sardegna, con valori di circa 2-6 mm/anno.

Il primo step della ricerca ha previsto la realizzazione della carta sismotettonica del settore compreso tra $\mathrm{i}$ golfi di Castellammare e Palermo, comprendendo sia la parte emersa che sommersa. In questo settore ricadono due volumi sismogenetici, prodotti dal campo di stress compressivo orientato NW-SE. Per quanto i risultati siano preliminari, è in corso di elaborazione un prodotto scientifico in grado di fornire informazioni utili in termini di pericolosità sismica in un settore che comprende sia aree continentali che marine. In questo senso, può rappresentare uno strumento importante in termini di monitoraggio delle strutture potenzialmente sismogenetiche e dei geohazard in ambiente marino e costiero. 


\title{
Caratterizzazione e Habitat mapping del Coralligeno di piattaforma lungo il margine continentale della Sicilia nord-occidentale
}

\author{
Zizzo E. ${ }^{1}$, Sulli A. ${ }^{1,2}$, Agate M. ${ }^{1}$, Lo Iacono C. ${ }^{3} \&$ Spatola D. ${ }^{1}$ \\ ${ }^{1}$ Dipartimento di Scienze della Terra e del Mare, Università degli Studi di Palermo. \\ ${ }^{2}$ Consorzio Nazionale Interuniversitario per le Scienze del Mare, Unità Locale di Ricerca Palermo. \\ ${ }^{3}$ National Oceanography Centre, Southampton, United Kingdom.
}

Corresponding author email: elisabetta.zizzo@unipa.it

Keywords:Coralligeno di piattaforma, Habitat mapping, Maxent.

Il Coralligeno di piattaforma è un indicatore ambientale e hotspot di biodiversità nelle zone marine costiere. Poiché esso viene considerato un ecosistema marino vulnerabile, numerose sono le azioni volte alla sua completa caratterizzazione e mappatura.

L'obiettivo del lavoro è di confrontare differenti metodologie utilizzate nell'analisi della distribuzione del Coralligeno di piattaforma, applicate al settore offshore della Sicilia nord-occidentale. Il focus del lavoro consiste nell'evidenziare come l'approccio multidisciplinare sia fondamentale nelle fasi di individuazione, caratterizzazione e predizione statistica della distribuzione delle associazioni biocenotiche, al fine di eseguire una mappatura degli habitat costieri.

L'area di studio si trova nel tratto di piattaforma continentale antistante i Monti di Palermo e compreso tra Isola delle Femmine e Capo Gallo.

Le mappe di distribuzione degli habitat possono essere ottenute attraverso tre approcci metodologici differenti. Il primo proviene dallo studio geologico-geofisico dei fondali, che ha permesso di cartografare le comunità bentoniche sulla base dei caratteri morfo-batimetrici. In questo senso il Coralligeno di piattaforma è stato classificato secondo Ballesteros (2006) e Giaccone (2007), differenziandolo in banchi ed orli e infralitorale e circalitorale, rispettivamente.

Il secondo approccio è quello biologico che consiste nel calibrare le facies acustiche ricavate dall'interpretazione dei dati Side Scan Sonar con i dati di campioni di fondo e validati attraverso immagini ROV; in questo modo vengono mappati e descritti i depositi di coralligeno con i relativi parametri quantitativi.

Il terzo approccio è quello statistico, basato sul modello di massima entropia (MaxEnt) che permette di ipotizzare la distribuzione della specie sulla base di dati di presenza (presence-only) e di parametri ambientali mappati per l'intera area di indagine. I parametri considerati sono: batimetria, acclività, esposizione, presenza di fluidi, aree ad erosione, sedimentologia. Oltre alla predizione sulle presenze della specie considerata, l'analisi statistica ha consentito di individuare i fattori che controllano la distribuzione del coralligeno lungo il margine, quali: fondali sabbiosi e, in subordine, sabbioso-limosi e substrato roccioso, inclinazione elevata, assenza di processi erosivi in atto ed emissione di fluidi.

L'integrazione di dati provenienti da tre diversi approcci ha reso possibile definire con maggiore dettaglio la distribuzione dei vari generi che costituiscono l'associazione a coralligeno dell'infralitorale (Rhodophyta, Cnidaria e Chlorophyta), che si distribuiscono prevalentemente lungo il limite piattaforma interna-piattaforma esterna (coralligeno di orlo), ad esclusione di alcune associazioni in banchi (probabilmente legati ad emissioni di fluidi.

Questo approccio può costituire uno strumento utile nell'individuazione e monitoraggio di aree marine da sottoporre a tutela ambientale. 


\section{Authors' Index}

Authors are listed alphabetically: For each contribution, the page number and the session are given.

Achilleos K.

Adami C.

Agate $\mathrm{M}$.

Aiello G.

Albano L.

Alberico I.

Alonso B.

Angeletti L.

Argnani A.

Armigliato A.

Artoni A.

Asioli A.

Baioni D.

Barca D.

Barreca G.

Basili R.

Basso D.

Belmonte G.

Beranzoli L.

Bohacs K.M.

Bonatti E.

Bonomo S.

Bortoluzzi G.

Bosman A.

Bracchi V.A.

Brutto F.

Budillon F.

Buongiorno Nardelli B.

Burrato P.

Butera F.

Cacho I.

Çağatay N.

Campiani E.

Capolongo D.

Cardone F.

Carluccio A.

Casalbore D.

Casas D.

Cascella A.

Català $\mathrm{A}$.

Cattaneo A.

Cavallaro D.

Ceccarelli E.M.

Cecchini S.

Chierici F.

Chiocci F.L.

Ciaccio G.

Ciccone F.

Cipriano G.
52

48

6,65

53

56

7

13

8

8

33

47

44,58

61

15

17, 37

34

10

52

29

44

42

23,36

9,27

30,48

10

33

7, 11, 39

11

17

46

$7,13,46,48,50$

50

23,36

36

58

12,26

13

57

29

$13,30,35,46,48,50,51$

25,59

11

62
Civile D.

63

Clare M.

40

Cocchi L.

25

Codiglia R.

14

Colizza E.

47

Coltelli M.

12,26

Conforti A.

11,20

Conte A.M.

30

Coren F.

14

Corrias N.

25,59

Corselli C.

10

Cosentino D.

39

Crocitti M. 15

Crupi A. $\quad 16$

Cultrera F 17

D'Angelo S. 43

D'Onghia G. $\quad 46$

Dalla Valle G. $\quad 18,19,44,58$

De Falco G. $\quad 11,20,54$

De Giosa F. 62

De Martino P. 29

De Rosa R. 15

Del Bianco F. 9

Del Vais C. 20

Delben A. 63

Demarte M. 21, 55

Dera R. $\quad 45$

Di Bella L. $\quad 30,46$

Di Blasi F. 22

Di Donato V. 45, 53

Di Fiore V. 7

Di Grigoli G. 25, $\quad 29$

Di Martino G. $\quad 11,31,39,60$

Di Rita F. 23

Di Stefano A. $\quad 24$

Distefano S. 24

Donato P. $\quad 15$

Donnarumma G.P. 29

Drexler T.M. $\quad 44$

Ercilla G. $\quad 50$

Estrada F. 13

Facchin L. 33

Fago P. $\quad 62$

Falco M. $\quad 53$

Faraci C. $\quad 45$

Ferrante V. 9, 27

Ferranti L. $\quad 17,37,38,45$

Ferraro L. 23, 39

Filippone M. 25 
Fiorentino A.

Firetto Carlino M.

Florindo F.

Foglini F.

Frezza V.

Gallerani A.

Gamberi F.

Gasparotto G.

Gasperini L.

Georgiou P.

Gerovasileiou V.

Giaramita L.

Giardina F.

Giardina F.

Giglio F.

Giustiniani M.

Gross F.

Guardato S.

Guido A.

Hadjioannou L.

Iannaccone G.

Iavarone $\mathrm{R}$.

Incarbona A.

Ingrassia $\mathrm{M}$.

Innangi S.

Insinga D.D.

Iorio $\mathrm{M}$.

Italiano F.

Iudicone D.

Ivaldi R.

Jimenez C.

Kelner M.

Kupryianova E.

Langone L.

Lanza S.

Leidi E.

Ligi $\mathrm{M}$.

Lindhorst $\mathrm{K}$.

Lirer F.

Lisco $\mathrm{S}$.

Lo Iacono C.

Loreto M.F.

Lubritto C.

Lucchi F.

Lurcock P.C.

Macelloni L.

Maesano F.E.

Magri D.

Magrini L.C.

Maisto F.

Malinverno E.

Manta K.

Mantopoulos P.
43

12,26

23

8,19

30,46

24

$18,19,22,24,44,58$

47

$9,20,27,47$

13

52

6

31

60

9

28

13

29

52

52

29

7

6

30

$11,31,39,60$

$15,23,45,53$

15,53

30

11

32

52

50

52

58

16

24

9,42

50

23,36

62

$6,40,65$

33,43

15

48

23

30

34

23

13

$13,35,50$

10

50

13
Margaritelli G.

23,36

Martino C.

Martorelli E.

30,51

Maselli V.

19, 44, 58

Mastandrea A.

52

Mastronuzzi G.

62

Meccariello M.

37,38

Meo A.

53

Mercorella A.

24

Migeon S. 13

Minisini D. $\quad 58$

Miserocchi S. $\quad 47$

Misuraca M. $\quad 39$

Molisso F. $\quad 45$

Monaco C. 17

Montagna P. $\quad 58$

Moretti M. 62

Morfis I. $\quad 13$

Moriconi R. $\quad 40$

Morticelli M.G. $\quad 64$

Muto F. 33

Nelson C.H. $\quad 47$

Nemola A. $\quad 25,59$

Nonnis O. 41

Paganelli D. $\quad 41$

Pagnoni G. 33

Palano M. $\quad 37$

Palmiotto C. $\quad 42,43$

Pampides I. 13

Panagiotopoulos I. 13

Pascucci V. 20

Passaro S. 6, 17, 45

Patanè D. 26

Patanè R.A. 13

Pavlidi-Palla M. $\quad 50$

Pazzini A. 41

Pellegrini C. $\quad 19,44$

Pepe F. $\quad 17,38,45,49$

Petrosino P. 23, 53

Pettenati F. 33

Pierdomenico M. 13, 46,50

Placenti F.

Polizzi S.

Polonia A.

Proietti R.

Quartau R.

Randazzo G.

Ravaioli M.

Rettori R.

Ricchi A.

Romagnoli C.

Romano S.

Rosso A.
43

23,36 
Rousakis G.

Rovere M.

Ruberti D.

Russo F.

Sacchi M.

Sakellariou D.

Sandron D.

Sañé E.

Sanfilippo R.

Sanna I.

Savelli D.

Savini A.

Scardino G.

Scarfi L.

Schulze I.

Senatore M.R.

Simeone S.

Sinapi L.

Sorce R.

Spatola D.

Sposato A.

Sprovieri M.

Stanghellini G.

Sulli A.

Sulpizio R.
13

19, 24, 44

49

52

45,49

13,50

33

51

52

20

61

10

62

17

13

53

54

32,55

25,59

65

13,30

6

20

6, 56, 64, 65

15
Sweet M.L.

44

Taliana D.

Tamburrino S.

Taviani M.

Tesi T.

Tessarolo C.

Tiberti M.M.

Tinivella U.

Tinti S.

Tonielli R.

Torelli L.

Tramontana M.

Tranne C.A.

Trincardi F.

Vaiani S.

Valenzano E.

Vallefuoco M.

Vigliotti M.

Volpi V.

Watteaux R.

Zanchetta G.

Zavitsanou A.

Zavitsanou A.

Zgur F.

Zizzo E.
57

6

8

58

25,59

34

28

33

$11,31,39,60$

47

61

48

$19,44,58$

47

62

6, 23

49

63

11

15

13

50

$14,26,33,63$

$56,64,65$ 


\section{SUPPORTED BY}

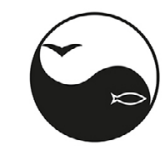

\section{CODEVINTEC \\ Tecnologie per le Scienze della Terra e del Mare}
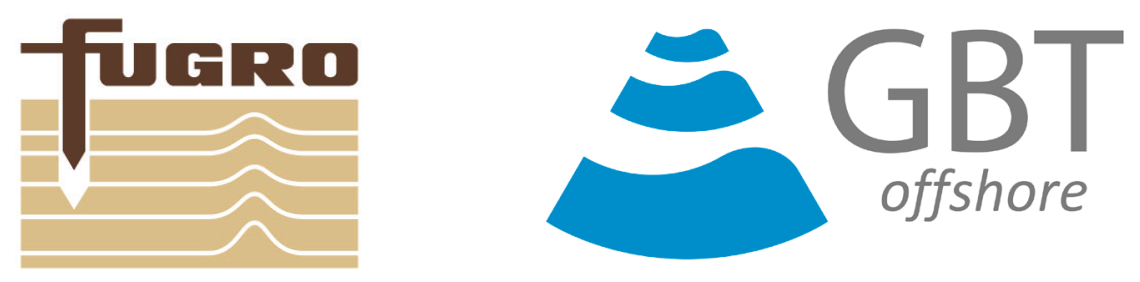